\title{
Diretrizes para o Estabelecimento de Melhoria de Processo Adequada a Empresas de Pequeno Porte
}

\author{
Mayb Iara Fiats \\ Orientadora: \\ Profa. Dra. Rosely Sanches
}

Dissertação apresentada ao Instituto de Ciências Matemáticas e de Computação da Universidade de São Paulo como parte dos requisitos para a obtenção do título de Mestre na Área de Ciências de Computação e Matemática Computacional.

USP - São Carlos

Outubro de 2000

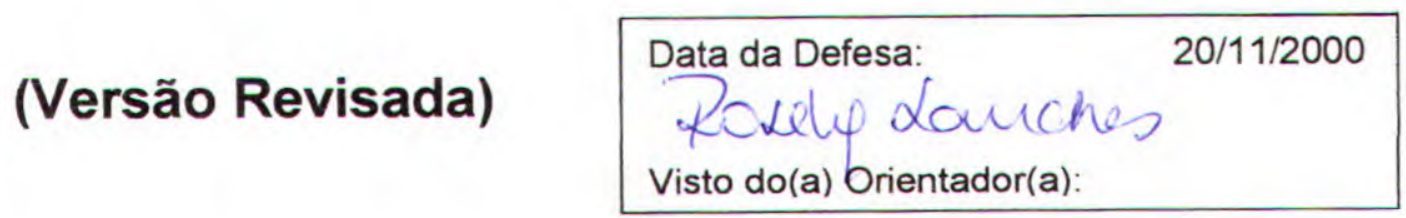




\title{
Diretrizes para o Estabelecimento de Melhoria de Processo Adequada a Empresas de Pequeno Porte
}

\author{
Mayb Iara Fiats \\ Orientadora: Profa. Dra. Rosely Sanches
}

Dissertação apresentada ao Instituto de Ciências Matemáticas e de Computação - USP, como parte dos requisitos para a obtenção do titulo de Mestre em Ciências Área: Ciências de Computação e Matemática Computacional.

USP - São Carlos

Outubro de 2000 
Aos meus pais Eurides e Eny,e ao meu noivo Camillo 


\section{Agradecimentos}

Primeiramente, a Deus, por ter me capacitado a realizar este trabalho e ter me confortado nos momentos mais difíceis.

À Profa Dra Rosely Sanches pela orientação deste trabalho e por estar sempre transmitindo muitos ensinamentos, incentivo, dedicação, amizade e paciência.

À toda minha familia, meus pais Eurides e Eny, aos meus irmãos Dilhermando, Jaiscilin, Daiane e Maria, por acompanhar-me, incentivar-me e principalmente, dedicar-me tanto carinho.

Ao Camillo, por estar sempre presente, transmitindo segurança e principalmente sendo a minha fonte de paz e tranqüilidade.

A minha tia Neci e minha prima Simone por sempre acreditarem em mim.

Aos amigos do coração Jorge, Flávia e Andrezza pelo carinho, amizade, paciência e por serem pessoas tão especiais.

Aos amigos Waine, Eglen, Rejane, Marisa, Jusane, Laura, Gláucio, Cristiane e Rerıato pelo companheirismo e amizade.

Ao Prof ${ }^{\circ} \mathrm{D} r^{\circ}$ Fredy João Valente, pela confiança depositada, pelo incentivo e apoio inicial.

Aos companheiros do LABES pela simpatia, amizade e prestatividade.

A todos os professores do ICMC que de alguma forma, contribuíram para o meu aprendizado.

Em especial ao Prof ${ }^{\circ} \mathrm{Dr}^{\circ}$ José Carlos Maldonado e a Profa Dra Solange Rezende.

Aos funcionários do ICMC, em especial à Beth, à Marilia, à Laura e as bibliotecárias que sempre foram muito prestativas.

A todos que de alguma forma contribuíram para a conclusão deste trabalho e que, pelo cansaço desse momento, posso estar cometendo o erro de esquecer.

A CNPq e a FAFICA pelo apoio financeiro. 


\section{Sumário}

pág.

Lista de Figuras................................................................................................. IV

Lista de Quadros.................................................................................................. V

Capítulo 1- Introdução...................................................................................... 1

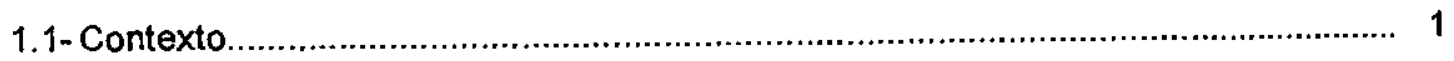

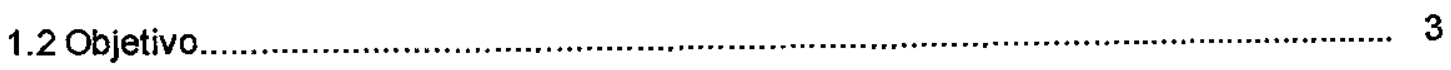

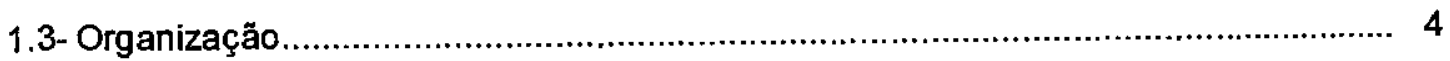

Capítulo 2- Melhoria de Processo de Software....................................................... 5

2.1-Consideraçőes Iniciais....................................................................................... 5

2.2-Atividades para Melhoria de Processo de Software............................................. 5

2.3- A abordagem IDEAL

2.4- A abordagem SPICE- parte 7: Guia para Melhoria de Processo............................. 8

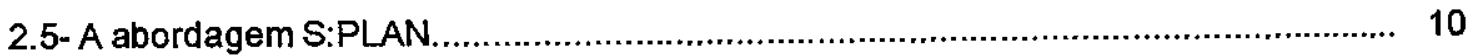

2.6- A abordagem Bootstrap............................................................................. 12

2.7- Considerações Finais................................................................................. 14

Capitulo 3- Estratégla para Iniciar Melhoria de Processo de Software...................... 15

3.1- Consideraçöes Iniciais....................................................................................... 15

3.2- Estratégia para Iniciar Melhoria de Processo de Software em Empresa de

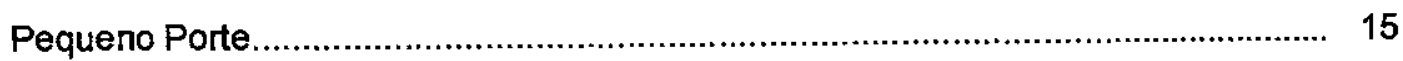

3.3-O SW-MM - Software-Capability Maturity Model................................................... 18

3.4-O Nivel dois do SW-CMM-Repetivel .......................................................... 18

3.5- Considerações Finais .................................................................................. 23

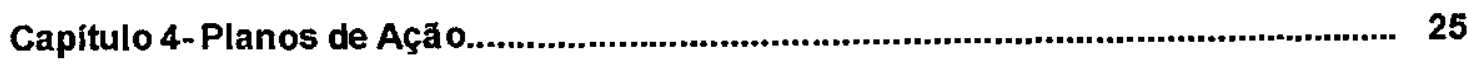

4.1- Consideraçס̄es Iniciais.................................................................................. 25

4.2- Desenvolvimento do Plano de Ação segundo a Abordagem IDEAL ......................... 25

4.2.1- Selecionar e Dar Treinamento em um Processo Estratégico de

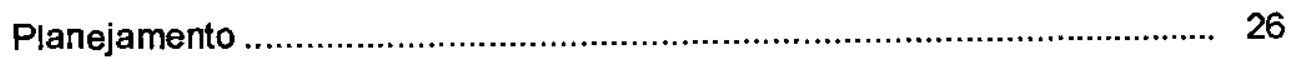

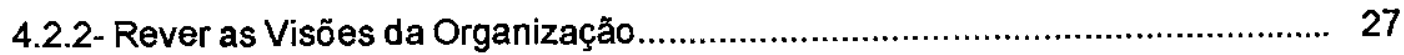

4.2.3- Rever o Plano de Negócios da Organização............................................... 28

4.2.4- Determinar o Objetivo Chave dos Negócios................................................ 28

4.2.5- Rever Esforços de Melhoria Passados......................................................... 28

4.2.6- Descrever as Motivações para a Melhoria................................................... 29

4.2.7-Identificar os Esforços de Melhoria Atuais e Futuros..................................... 29 
4.2.8- Identificar os Papéis e Responsabilidades .............................................. 29

4.2.9- Priorizar as Atividades e Desenvolver uma Agenda de Melhorias................ 29

4.2.10- Reconciliar Esforços de Melhoria Existentes com as Descobertas e

Recomendações Armazenadas........................................................... 30

4.2.11- Transformar os Objetivos de Melhoria de Processo de Software Gerais em Objetivos Especificos......................................................................... 30

4.2.12- Criar ou Atualizar o Plano de Melhoria de Processo de Software............... 30

4.2.13- Rever e Aprovar o Plano de Melhoria de Processo de Software................ 30

4.2.14- Formar o Grupo de Trabalho Técnico................................................... 30

4.3- Desenvolvimerto do Plano de Ação Segundo a Abordagem da parte 7 do SPICE

4.3.1-Identificar e Priorizar as Áreas de Melhoria............................................... 31

4.3.2- Desenvolver o Plano de Ação.................................................................. 33

4.4. Desenvolvimento do Plano de Ação segundo a Abordagem S:PLAN................... 33

4.4.1 - Preparação da Abordagem................................................................... 33

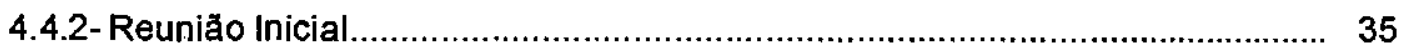

4.4.3- Preparação das Entrevistas..................................................................... 35

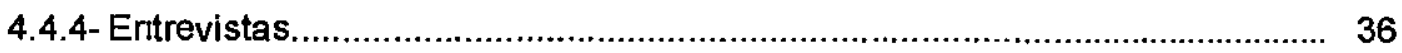

4.4.5- Preparação do Plano de Ação Preliminar................................................... 37

4.4.6- Reuniăo com a Administraçăo Superior ......................................................... 37

4.4.7-Preparação do Plano de Ação Defiritivo................................................... 37

4.4.8- Apresentação do Plano de Ação Defiritivo.................................................. 38

4.5- Desenvolvimento do Plano de Ação Segundo a Abordagem Bootstrap................... 38

4.5.1-Verificação dos Resultados da Avaliação..................................................... 38

4.5.2- Definição do Perfil Objetivo ........................................................................ 39

4.5.3- Identificação das Prioridades .................................................................. 39

4.5.4- Definição das Ações de Melhoria............................................................. 41

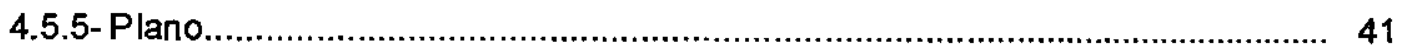

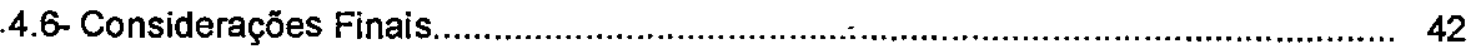

Capitulo 5- Diretrizes para o Estabelecimento de Melhoria de Processo de

Software............................................................................................... 43

5.1- Considerações Iniciais................................................................................. 43

5.2- As Diretrizes para o Estabelecimento de Melhoria de Processo de Software .......... 43

5.3- Passo 1- Estabelecer Prioridades .........................................................................4 46

5.3.1- O Modelo do Plano para Condução da Reunião de.Pré-Condições.............. 47

5.3.2- A Palestra de Pré-Condições ............................................................... 47 
5.3.3-O Questionário de Pré-Condições....................................................... 48

5.3.4- Atividades para o Estabelecimento das Prioridades .................................. 51

Atividade 1- Preparaçăo da Reunião para o Preenchimerito do Questionário de Pré-Condições

Atividade 2- Realização da Reuniăo para o Preenchimento do Questionário de Pré-Condições...................................................................... 52

Atividade 3- Análise dos Dados............................................................. 53

Atividade 4- Priorizaçăo.............................................................................. 54

5.4- Passo 2- Desenvolver Abordagem.................................................................. 55

5.4.1- O Relatório de Pré-Condiçőes.............................................................. 56

5.4.2- O Relatório de Atividades.................................................................... 58

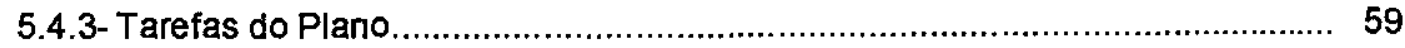

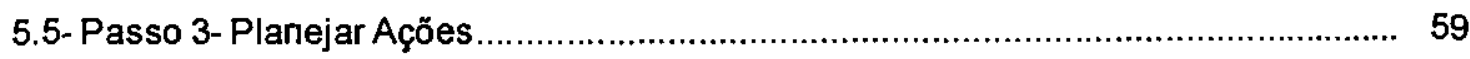

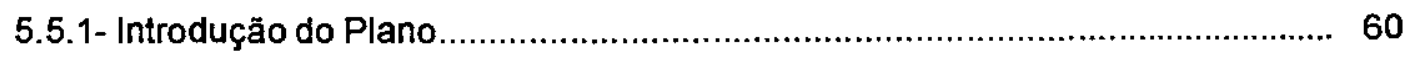

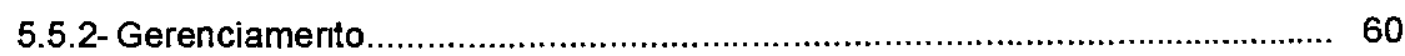

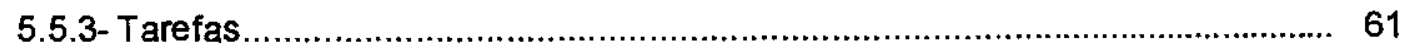

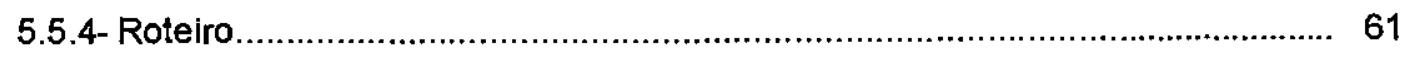

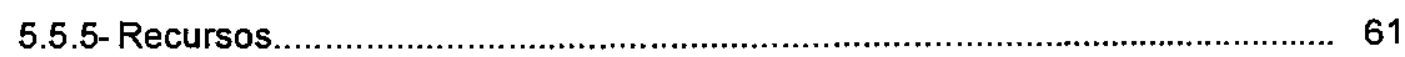

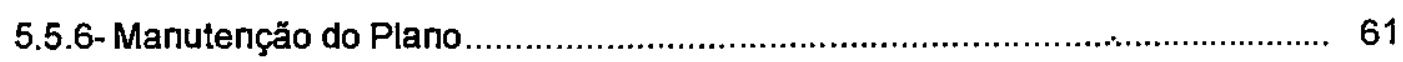

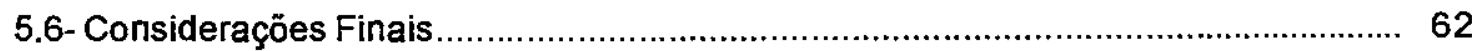

Capitulo 6. Uma Análise Simples da Aplicabilidade das Diretrizes para o

Estabelecimento de Melhoria de Processo......................................... 63

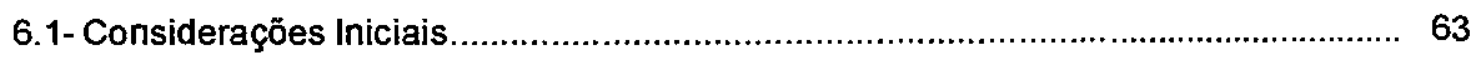

6.2-Araálise de Aplicabilidade das Diretrizes propostas............................................... 63

6.2.1- Reunião com a Participação dos Profissionais de Empresas

Desenvolvedoras de Software de Pequeno Porte........................................ 64

6.2.2- reuniåo com a Participação dos Profissionais da Área Acadêmica................. 65

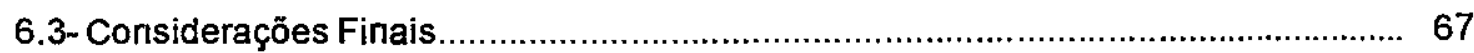

Capitulo 7 Conclusర̋es e Trabalhos Futuros......................................................... 69

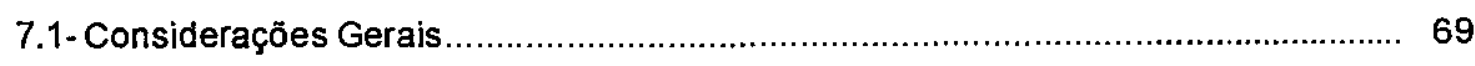

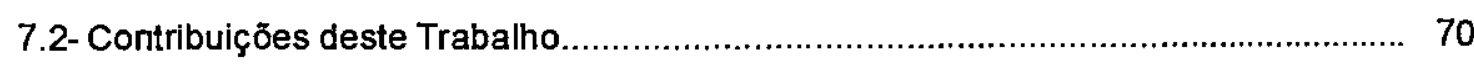

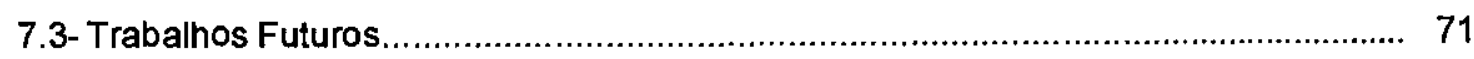

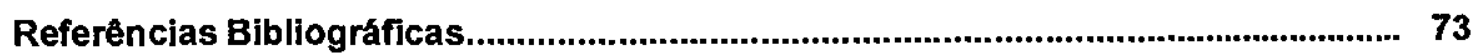

Bibliografia Complementar..................................................................................... 77

Apêndice A-A Palestra de Pré-Condiçōes................................................................ A1

Apêndice B-O Questionário de Pré-Condiçōes......................................................... B1 


\section{Lista de Figuras}

pág.

Fig. 1.1- Objetivo do Trabalho de Dissertaçăo.......................................................... 3

Fig. 2.1- A Abordagem IDEAL............................................................................ 7

Fig. 2.2- Componentes do Modelo SPICE............................................................... 8

Fig. 23-Passos para Melhoria do Processo de Software.......................................... 10

Fig. 2.4- Fluxo de Atividades do S:PRIME ........................................................... 11

Fig. 2.5- Arquitetura do Modelo Bootstrap............................................................ 13

Fig. 4.1 - Fluxo para a Fase de Estabelecimento...................................................... 27

Fig. 4.2-Identificaçăo e Prionizaçăo das Áreas de Melhoria......................................... 32

Fig. 4.3-Atividades que Compठ́em a Abordagem S:PLAN........................................ 33

Fig. 4.4-Atividades para o Desenvolvimento do Plano de Açăo...................................... 39

Fig. 5.1-Informaçסes sobre a Área-Chave Garantia de Qualidade de Software.............. 44

Fig. 5.2-Informaçס̃es sobre a Área-Chave Gerenciamento de Configuração de

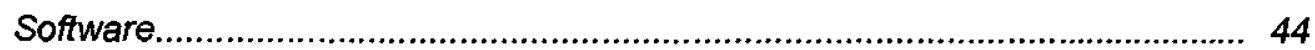

Fig. 5.3-Passos da Estratégia de Estabelecimento de Melhoria de Processo de

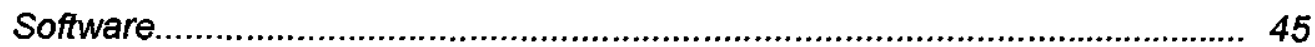

Fig 5.4-Estabelecimento das Prioridades........................................................... 46

Fig. 5.5-Cronograma da Palestra de Pré-Condiçб́es.................................................. 48

Fig. 5.6-Desenvolvimento da Abordagem.......................................................... 56 


\section{Lista de Quadros}

pág.

Quadro 5.1-Plano para a Condução da Reuniâo de Pré-Condiçбes................................ 50

Quadro 5.2- Número de Pré-Condiçбes e valor de cada Pré-Condiçăo por KPA.............. 53

Quadro 5.3-Relatório de Prioridades ........................................................................ 55

Quadro 5.4-KPA Gerenciamento de Requisitos do Questionário de Pré-Condiçбes....... 57

Quadro 5.5-Relatório de Pré-Condiçбes................................................................. 57

Quadro 5.6-KPA Gerenciamento de Requisitos do Questionário de Avaliação................ 58

Quadro 5.7- Relatorio de Atividades........................................................................ 58

Quadro 5.8- Tarefas do Plano de Ação..................................................................... 59

Quadro 5.9-Estrutura do Plano de Ação.................................................................... 60

Quadro 6.1-Questరes consideradas na análise da aplicabilidade das Diretrizes para o Estabelecimento de Melhoria de Processo de Software.............................. 66

Quadro 6.2-Respostas dos Profissionais das Empresas de Pequeno Porte.................. 66

Quadro 6.3-Resposta dos Profissionais da Área Acadêmica........................................ 67 


\section{Resumo}

A partir dos anos 90 , a qualidade tornou-se uma necessidade básica na luta pelo mercado competitivo e acabou afetando a indústria de software. Os deserivolvedores de software são obrigados a aperfeiçoarem o seu produto final para continuarem competindo no mercado. Após alguns arios de experiência no desenvolvimento de software, percebeu-se que alguns fatores de qualidade considerados pelos clientes, estão mais relacionados ao processo de software do que ao produto final. A melhoria do processo de software aumenta as chances de se obter um produto que atenda as expectativas dos clientes. No entarito, a realização de uma melhoria de processo de software não é uma tarefa simples e envolve vários fatores. Para auxiliar a tarefa de melhorar o processo de software, existem hoje na literatura vários modelos de melhoria como por exemplo o SW-CMM (Software-Capability Maturity Model). Porém, a maioria dos modelos de melhoria existem são voltados para as empresas de grande porte, possuindo uma estrutura complexa e "fechada" que dificilmente se ajustam às necessidades das empresas desenvolvedoras de software brasileiras, as quais, são na sua maioria, empresas de pequeno porte.

Dentro deste contexto, este trabalho apresenta diretrizes para orientar clara e objetivamente a melhoria de processo de software. As diretrizes seguem os passos da fase de estabelecimento da Abordagem IDEAL - Estabelecimento de Prioridades, Desenvolvimento da Abordagem e Planejamento de Açס́es - e considera algumas idéias obtidas através do estudo das abordagens S:PLAN, Bootstrap e a parte 7 do Modelo SPICE. 


\begin{abstract}
From 90's, the quality has became a common need for the competitive business and it ended up affecting the software industry. The software developers must improve their final product in order to keep on business. After some years of experience in the software development, it was noticed that some quality factors, considered by the customers, are more related to the software process than to the final product. The improvement of the software process increases the possibilities to achieve a product that is in accordance with the customers expectations. However, the accomplishment of the improvement of the software process is not a simple task and it involves several factors. To aid the task of improving software process, there are several improvement models in the literature, for instance SW-CMM (Software-Capability Maturity Model). Most of the current improvement models is conceming on big enterprise and they have a complex and "closed" structure, which are difficult to be adjusted to the needs of the Brazilian software development enterprises, that are usually small ones.

Based on that context, this work presents guidelines to aid the improvement of software process. These guidelines follow the steps of the establishment phase of the IDEAL Approach Establishment of Priorities, Development of the Approach and Planning of Actions - and they consider some ideas obtained through the study of the following approaches S:PLAN, Bootstrap and part 7 of SPICE Model.
\end{abstract}




\section{Capítulo 1} Introdução

\section{1- Contexto}

A qualidade tem sido um fator de diferenciação no mercado atual. A exigência por qualidade tem aumentado em todas as áreas e afetado também a indústria de software. Com os computadores, cada vez mais, fazendo parte da vida das pessoas, a produção de softwares vem aumentando e tornando os clientes mais exigentes. A grande exigência dos clientes por melhores softwares tem obrigado os desenvolvedores a aperfeiçoarem o seu produto final para continuarem competindo no mercado. Esses clientes deixaram de se preocupar apenas com o preço e passaram a buscar um produto mais confiável e com mais qualidade (Gillies, 1993).

Após alguns anos de experiência no desenvolvimento de software, percebeu-se que existem alguns fatores de qualidade, considerados pelos clientes, não estão relacionados especificamente às características de qualidade do produto final. Esses fatores relacionam-se mais ao processo de software, à forma como ele é gerenciado e controlado.

O processo de software consiste em uma série de atividades, políticas, práticas, eventos, ferramentas e métodos que garantem, técnica e administrativamente que o software possa ser desenvolvido de maneira organizada, disciplinada e previsivel (Paulk et al., 1993). Esse processo define as atividades de desenvolvimento de software, abrangendo as pessoas e as suas 
responsabilidades, os recursos, os cronogramas, os orçameritos, o processo de desenvolvimento em si, as técnicas, os métodos, as ferramentas e os outros elementos relacionados ao software (Ahlgren, 1999).

Ao se melhorar a qualidade do processo de software, tem-se maior probabilidade de se obter um produto final mais adequado às expectativas do cliente, no entanto, a realização de uma melhoria do processo de software não é uma tarefa trivial. Para que o processo de software possa cumprir seus objetivos é necessário um planejamerito detalhado que mostre a realidade do processo atual, a meta que se almeja com a melhoria, a estratégia para se atingir essa meta e os planıs de ação. Também são necessários patrocínio ao processo e incentivo às pessoas, pois são elas um dos fatores complicadores das mudanças exigidas pela melhoria de processo de software (P-CMM, 2000).

Para auxiliar a melhoria do processo existem abordagens que descrevem como a organização pode avaliar o seu estado atual e a partir dessa avaliação procurar melhorar o seu processo. A melhoria do processo deve ser conscierite e o grau a ser atingido deve ser bem definido (Pfleeger, 1994). Existem atualmente várias Abordagens de Melhoria de Processo de Software, dentre elas pode-se citar, por exemplo a abordagem PDCA (Werkema, 1995), a abordagem IDEAL (Gremba, 1999), a abordagem da parte 7 do Modelo SPICE $\quad$ (SPICE7, 1997) e a abordagem Bootstrap (Kuvaja, 1994).

Com base nessas abordagens, vánios modelos de melhoria de processo de software foram criados, como por exemplo o SW-CMM (Software-Capability Maturity Model), desenvolvido pelo SEI (Software Engineering Institute) e baseado na abordagem IDEAL (Paulk et al., 1993). Esses modelos, no entanto, são projetados para empresas de grande porte e dificilmente ajustam-se à realidade da maioria das empresas brasileiras desenvolvedoras de software (de acordo com o Ministério de Ciência e Tecnologia, $77 \%$ dessas empresas são de pequeno ou médio porte (Qualidade,1998)).

Geralmente as empresas de pequeno ou médio porte não possuem uma ampla irifraestrutura, um grande número de pessoas envolvidas no processo e nem tampouco recursos e tempo disponiveis, tornando praticamente inviável a aplicação de modelos de melhoria tais como o SW-CMM. Mesmo quando essas empresas tertam iniciar a melhoria de processo usando um desses modelos, elas esbarram em um empecilho muito grande. Os modelos são "fechados", eles indicam "o que" deve ser feito, mas não dizem "como" as atividades que proporcionam a melhoria devem ser realizadas. 
Antes de se definir os passos para melhorar o processo de software, primeiramente as empresas devem realizar a avaliação desse processo. Com o objetivo de auxiliar, principalmente as empresas de pequeno porte nessa avaliação, foi desenvolvido, no ICMC-USP em 1998, um trabalho que define, relaciona e organiza as principais atividades que devem ser realizadas para avaliar um processo de software em relação ao nivel dois do SW-CMM (Endo, 1998). Esse trabalho toma como base a abordagem IDEAL, cumprindo a fase de inicialização e diagnóstico dentro de um programa de melhoria de processo de software. O trabalho de Endo (1998) será apresentado nessa dissertação somente a titulo de ilustração. As diretrizes, propostas nessa dissertação, não estão diretamente ligadas à estratégia desenvolvida por Endo (1998).

\section{2 - Objetivo}

Visando atender principalmente as necessidades das empresas de pequeno porte, o objetivo deste trabalho é apresentar diretrizes para orientar de maneira clara e objetiva a melhoria do processo de software. As diretrizes - Diretrizes para o Estabelecimento de Melhoria de Processo Adequada a Empresas de Pequeno Porte - seguem os passos da fase de estabelecimento da Abordagem IDEAL - Estabelecimento de Prioridades, Desenvolvimento da Abordagem e Planejamento de Ações-e considera algumas idéias obtidas através do estudo das abordagens IDEAL, S:PLAN, Bootstrap e a parte 7 do Modelo SPICE (Figura 1.1).

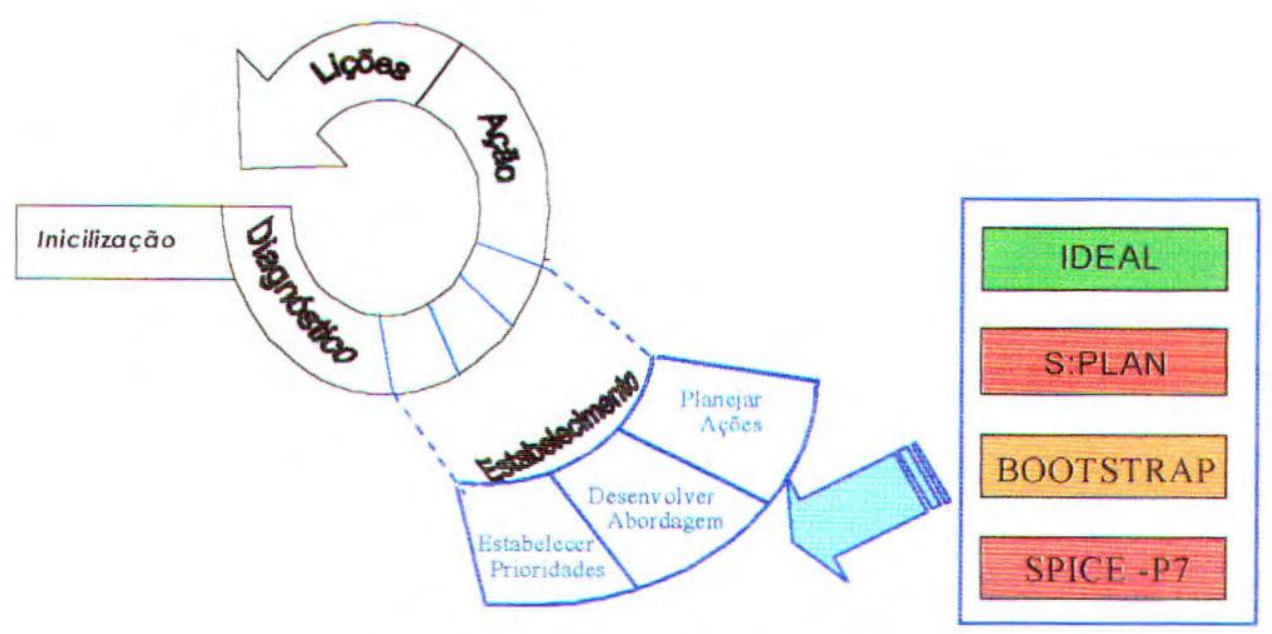

Figura 1.1- Objetivo do Trabalho 


\section{3 - Organização do Trabalho}

Este trabalho está organizado em seis capítulos e dois apêndices. Este primeiro capítulo de introdução expõe o contexto no qual se insere este trabalho e o seu principal objetivo.

No Capítulo 2 descreve-se o contexto de melhoria de processo de software e apresentase as abordagens de melhoria de processo de software IDEAL, SPICE - parte7, S:PLAN e Bootstrap.

No Capítulo 3 apresenta-se, brevemente e a título de ilustração, a Estratégia para Iniciar Melhoria de Processo de Software desenvolvida por Endo (1988). Apresenta-se também um resumo do SW-CMM, explicando-se as seis áreas-chave de processo do nível dois desse modelo, uma vez que esse é o nível considerado pela estratégia de Endo (1998).

No Capítulo 4 descreve-se o desenvolvimento do plano de ação das abordagens de melhoria de processo de software IDEAL, SPICE - parte 7, S:PLAN e Bootstrap, visto que, as diretrizes propostas nessa dissertação, baseiam-se em idéias obtidas através do estudo do desenvolvimento do plano de ação dessas abordagens.

No Capítulo 5 apresenta-se o desenvolvimento dos três passos das Diretrizes para o Estabelecimento de Melhoria de Processo Adequada as Empresas de Pequeno Porte Estabelecimento das Prionidades, Desenvolvimento da Abordagem e Planejamento de Açס̃es bem como todos os elementos envolvidos.

No Capítulo 6 apresenta-se uma análise simples da aplicabilidade das Diretrizes para o Estabelecimento de Melhoria de Processo de as Empresas de Pequeno Porte, propostas nessa dissertação,

Finalmente, no Capitulo 7 apresenta as conclusões e as propostas para futuras pesquisas que podem ser desenvolvidas.

Nos Apêndices A e B, apresentam-se respectivamente, a Palestra e o Questionário de Pré-Condições, ambos desenvolvidos e utilizados durante o primeiro passo das Diretrizes Estabelecimento de Prioridades. 


\section{Capítulo 2}

\section{Melhoria de Processo de Software}

\section{1 - Considerações Iniciais}

Neste capítulo são apresentados o contexto de melhoria de processo de software e algumas características, consideradas importantes para este trabalho, sobre as Abordagens de Melhoria de Processo de Software IDEAL, SPICE -parte7, S:PLAN e Bootstrap.

\section{2 - Atividades para Melhoria de Processo de Software}

O aumento crescente do reconhecimento, por parte das empresas desenvolvedoras de software, da importância de se melhorar a qualidade do seu produto de software, tem feito com que cada vez mais, as empresas preocupem-se com a melhoria do controle sobre todos os elementos envolvidos com esse processo.

A melhoria de processo de software define as atividades que uma organização deve seguir para melhorar o seu processo de software ao longo do tempo. O primeiro passo é considerar que todas as tarefas relacionadas ao desenvolvimento do software possam ser controladas, medidas e melhoradas. A melhoria do processo aumenta a visibilidade sobre 0 mesmo, o que torna todas as atividades, durarite o desenvolvimento e manutenção do software, mais gerenciáveis. Isso conseqüentemente reduz os custos e torna os cronogramas mais confiáveis, além de facilitar a adoção de novas tecnologias (Maidantchik, 1996). 
Por se tratar de uma decisão que depende de toda a organização e de seus resultados serem, na maioria das vezes, perceptíveis somente a longo prazo, as pessoas tendem a adiar a implantação da melhoria de processo. Melhoria de processo não é uma atividade trivial, sendo que vários dos elementos a serem considerados para a sua implantação erivolvem a própria organização, tais como comprometimentos, responsabilidades, recursos, habilidades profissionais e gerenciais (Glass, 1998).

Para se obter qualidade em um processo de software, é necessário que as tarefas, responsabilidades, atividades, funções, recursos e pessoas que farão parte do processo a ser adotado sejam estudados, preparados e planejados com antecedência, o que evidencla a necessidade de se estabelecer uma abordagem para melhoria de processo de software. É através da utilização de uma abordagem de melhoria, que a organização poderá avaliar o seu estado atual do processo, ou seja, em que nivel de maturidade ele se encontra e, a partir dessa avaliação, procurar as melhorias. É importante ressaltar que, independente da abordagem de melhoria a ser adotada pela empresa, a melhoria de processo deve ser consciente e o grau a ser atingido deve ser bem definido (Curtis, 1998).

Existem atualmente várias Abordagens de Melhoria de Processo de Software, dentre elas pode-se citar a abordagem IDEAL (Gremba, 1999), a abordagem da parte 7 do Modelo SPICE (SPICE7, 1997), a abordagem S-PLAN (Intec, 1999) e a abordagem Bootstrap (Kuvaja, 1994), que serão apresentados a seguir:

\section{3 - A abordagem IDEAL}

A abordagem IDEAL (Figura 2.1) foi desenvolvida pelo SEI (Software Engineering Institute) e estabelece um programa de melhoria contínua de processo de software. IDEAL é um acrônimo que engloba cinco fases do ciclo de melhoria de processo de software - Inicialização (Initiating), Diagnóstico (Diagnosing), Estabelecimento (Establishing), Ação (Acting) e Lições (Leveraging), o qual contém as atividades de diagnóstico do processo atual, a elaboração de um plano para melhoria, a implantação deste plano e a confirmação das atividades implantadas através do diagnóstico do processo, iniciando novamente o ciclo (Gremba, 1999).

- Fase de inicialização: Nessa fase são identificados os motivos e as razões para as mudanças no processo de software, os quais necessitam ser extremamente claros e evidentes. 
- Fase de Diagnóstico: Nessa fase duas características da organização são desenvolvidas: o estado atual do processo de software da organização e o estado futuro desejado; esses estados serão utilizados para desenvolver as recomendações de como proceder nas fases subseqüentes.

- Fase de Estabelecimento: A proposta dessa fase é definir prioridades para as alterações, desenvolver uma abordagem para a realização do trabalho, identificar recursos disponíveis e elaborar um plano de ação detalhado, o qual contém horários, tarefas, recursos, responsabilidades e qualquer outro elemento requerido pela organização.

O detalhamento da fase de estabelecimento da abordagem IDEAL, a qual culmirra em um plano de ação, é apresentado no quarto capítulo dessa dissertação, devido a sua importância ro contexto desse trabalho.

- Fase de Ação: As atividades dessa fase ajudam a organização a implementar o trabalho que foi contextualizado e planejado nas três fases anteriores. Essas atividades tipicamente corisomem mais tempo e recursos que todas as outras combinadas.

- Fase de Lições: Nessa fase as experiências são revisadas, para arralisar o que foi realizado e como a organização pode implementar mudanças mais efetivamertte, no futuro. As lições são coletadas, analisadas e documentadas. As necessidades identificadas ra fase de inicialização são reexaminadas para verificar se foram atendidas, são fornecidas propostas de alterações para melhoria futura.

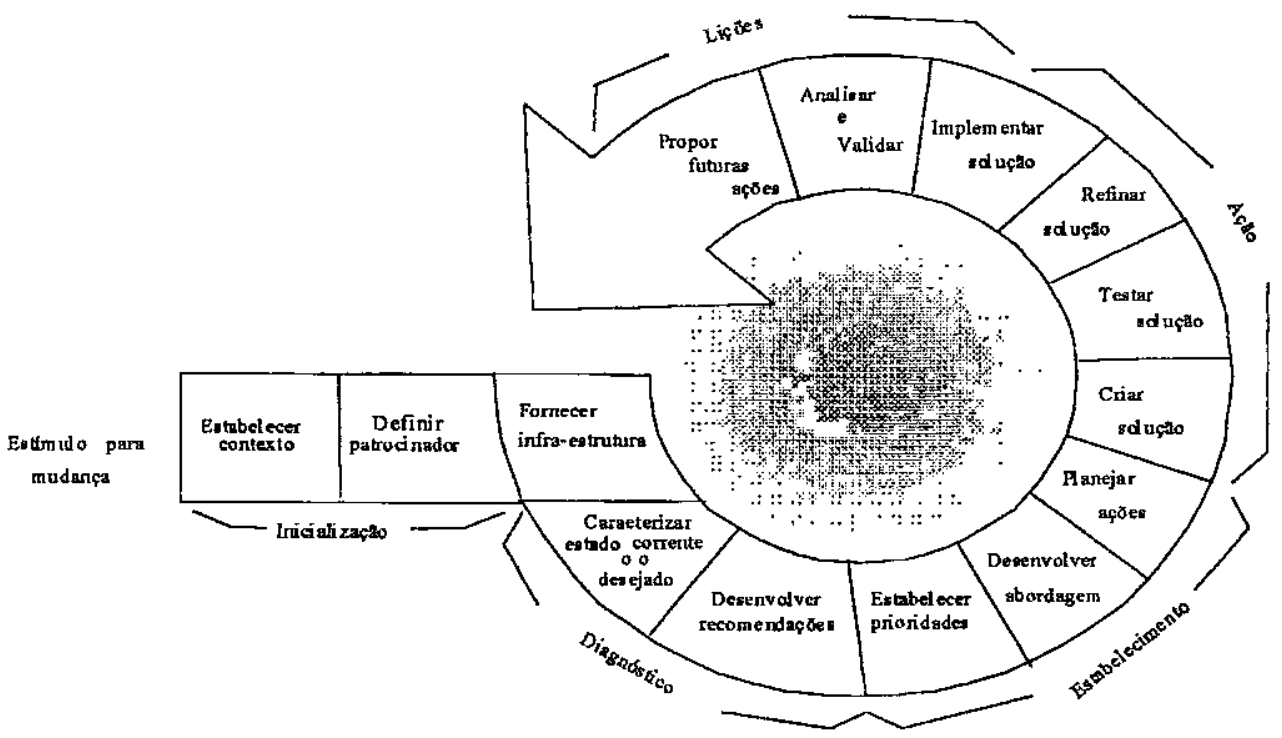

Figura 2.1: Abordagem IDEAL (IDEAL, 1999). 


\section{4 - A abordagem SPICE- parte 7: Guia para Melhoria de Processo}

Com o objetivo de prover um padrăo para modelos de avaliação e de melhoria de processo de software, teve início em 1993 o projeto SPICE.

A filosofia deste modelo é agrupar em um mesmo modelo várias características interessantes já constantes em outros modelos existentes, como por exemplo, o SW-CMM. O Modelo SPICE é subdivido em nove partes (Figura 2.2), sendo que na parte 7 é apresentado o Guia para Melhoria de Processo (SPICE1, 1997).

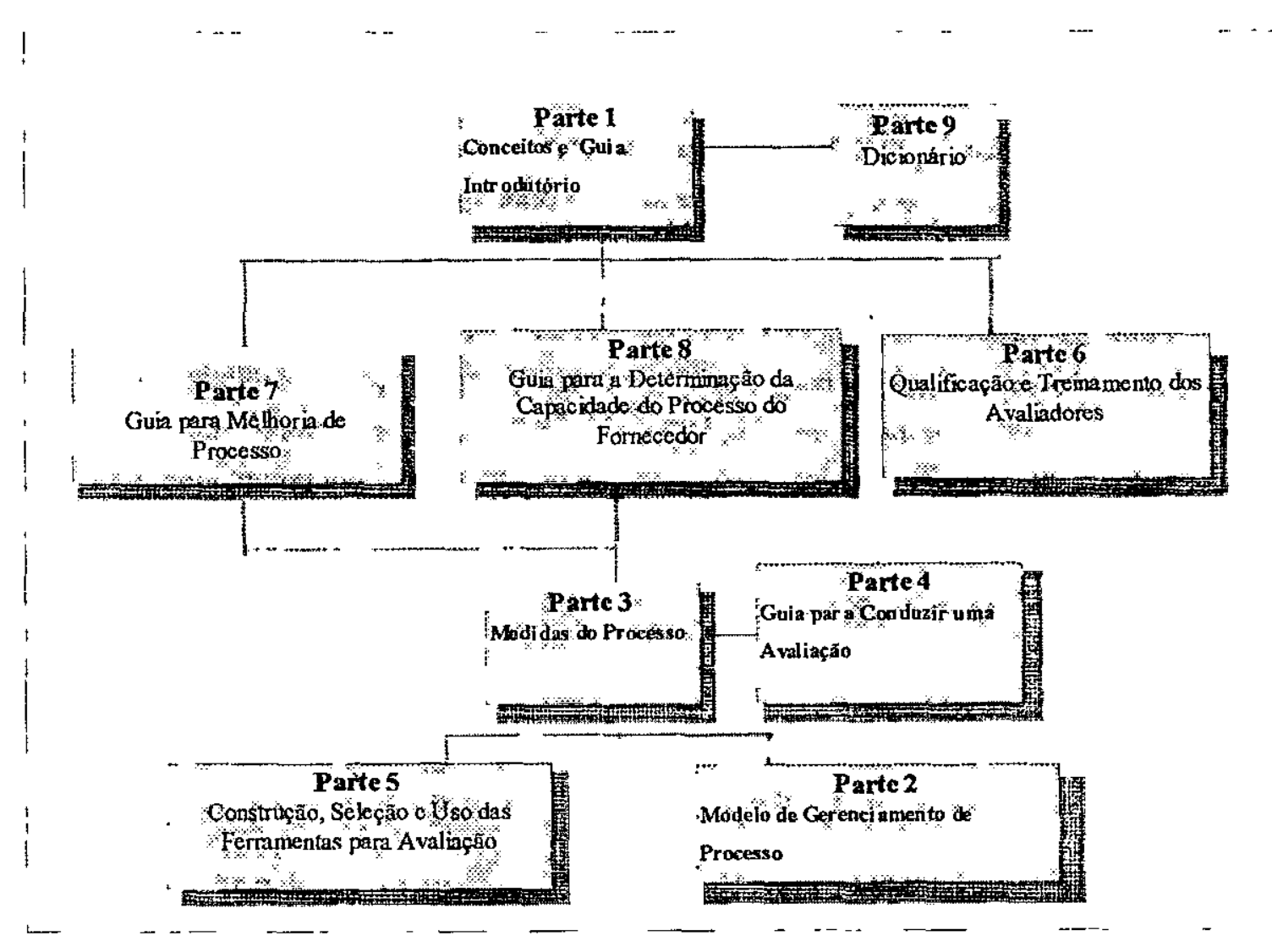

Figura 2.2 Componentes do Modelo SPICE (SPICE, 1997)

O Guia para Melhoria de Processo proposto na parte 7 do SPICE se destina a prover os seguintes tópicos (SPICE7, 1999): 
- Uma visão de melhoria de processos: descreve os fatores que guiam as melhorias de processo de software e os princípios gerais nos quais essas melhorias estão alicerçadas.

- Questões culturais: Aborda os aspectos de cultura organizacional que são críticos para o sucesso da melhoria de processo, os quais englobam:

- As responsabilidades da gerência e da liderança da organização,

- As atitudes e os comportamentos da organização que podem ser mudados com uma melhoria de processo efetiva,

- Os objetivos e as motivações da melhoria de processo,

- A comunicação e o trabalho em equipe, o qual exige confiarıça e habilidade, permitindo assim um alto grau de paralelismo no trabalho,

- Uma boa política de reconhecimento de esforços, que deve ser adotada para encorajar atitudes e comportamentos necessários para uma melhoria de processo bem sucedida e,

- Treinamentos contínuos, os quais são essenciais para criação e manuterıção de um ambiente adequado à melhoria de processo.

- Gerenciamento: Descreve a melhoria do processo de software sob uma perspectiva de gerenciamento, que engloba uma melhoria de processo de software organizada, um planejamento para melhoria de processo, uma medição da melhoria de processo e uma revisão das atividades de melhoria de processo.

- Uma metodologia para melhoria de processos: apresenta um modelo de oito passos para melhorar o processo de software, dentro de um ciclo de melhoria continuo (Figura 2.3). Dentro desse modelo de oito passos, o quarto passo destina-se a analisar os resultados da avaliação e derivar o plano de ação. As atividades realizadas nesse passo serão apresentadas no quarto capitulo dessa dissertação. 


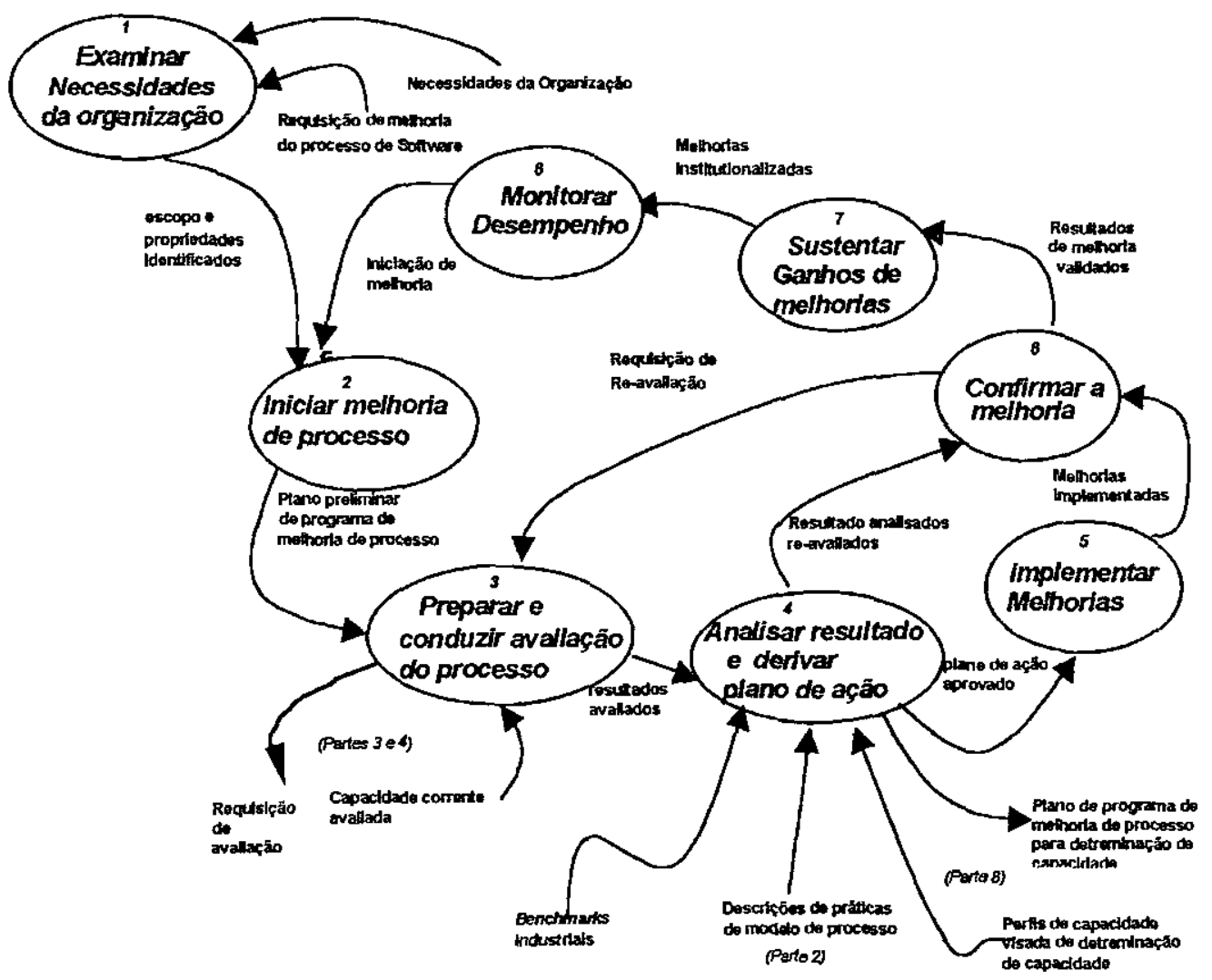

Figura 2.3 - Passos para Melhoria de Processo de Software (SPICE7, 1997)

\section{5 - A abordagem S:PLAN}

Para identificar, mapear e avaliar os riscos relacionados ao processo de software foi desenvolvido pela GrafP Technolologies em colaboração com o Applied Software Engineering Center (ASEC), o Modelo S: PRIME (Software: Process Risk Identification, Mapping and Evaluation), o qual é baseado na Taxonomy - Basedy Risk Identification e no SW-CMM. O Modelo S:PRIME identifica os pontos fortes'e fracos do processo de software de uma organização (Wilson, 1998).

As atividades desse modelo (Figura 2.4) envolvem a distribuição de dois questionários aplicados a grupos diferentes de pessoas.

O objetivo do primeiro questionário, freqüentemente chamado de Questionário de Riscos, é identificar a percepção que os gerentes e os líderes de projeto, têm do nível de riscos nos projetos pelos quais são responsáveis. O segundo questionário, o Questionário das Práticas, é endereçado ao restante da equipe envolvida no desenvolvimento e manutenção de projetos de software da orgánização. O Questionário das Práticas visa a determinar a competência atual do 
projeto ou da organização, através de questões relacionadas às treze áreas-chave que compõem os níveis 2 e 3 do SW-CMM, além outras duas áreas-chave desenvolvidas pelo próprio S:PRIME, denominadas Serviço ao Cliente e Cultura Corporativa. A competência do processo, avaliada através das respostas desse questionário, é então usada para modular o nível de percepção de risco do gerente ou do líder do projeto, avaliado pelo questionário anterior (Intec, 1999).

Através dessas análises é possivel identificar as áreas onde os riscos são altos e a partir disso preparar um plano de ação para sanar os problemas e evitar os riscos. Porém, o Modelo S:PRIME não cobre a fase de preparação do plano de ação, limitando-se à identificação dos riscos.

Dando continuidade ao Modelo S:PRIME, a Intec, uma empresa criada em 1968 e situada no Chile (Intec, 1999), desenvolveu uma abordagem denominada S:PLAN, que permite gerar um plano de ação com o objetivo de diminuir os riscos associados aos processos de manutenção e desenvolvimento de software.

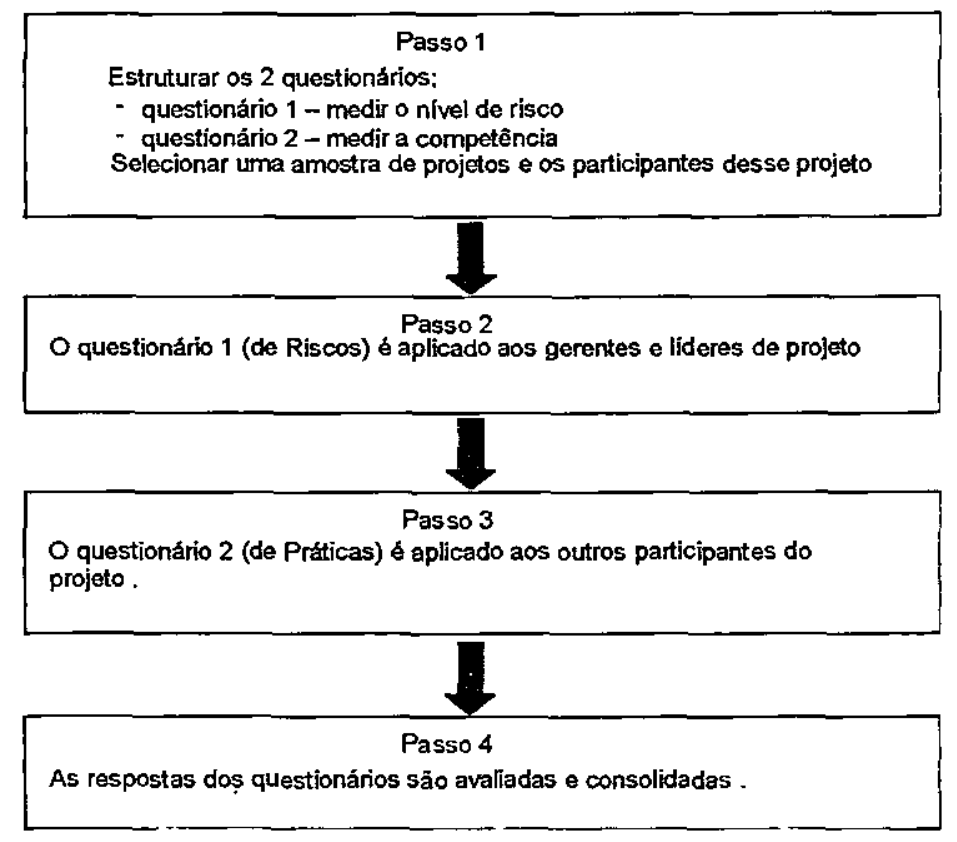

Figura 2.4 - Fluxo de atividades do S:PRIME

A abordagem S:PLAN valida e prioriza os riscos identificados durante a avaliação do S:PRIME e busca encontrar um número menor de práticas, que cubra a major quantidade de riscos possíveis, de modo a maximizar a relação custo benefício do plano de ação. Em um consenso com todos os envolvidos no processo de software, as tarefas são definidas, os custos 
são estimados e as responsabilidades e recursos são designados. Finalmente, o plano de ação é apresentado à administração de forma que essa tenha à disposição todas as informações para decidir quais práticas deverão ser implementadas, considerando as restrições pressupostas e as necessidades da organização.

Relacionando o Modelo S:PRIME e a abordagem S:PLAN com o ciclo de melhoria contínuo da abordagem IDEAL, percebe-se que o Modelo S:PRIME cobre a fase de diagnóstico, realizando a avaliação e caracterização das práticas atuais. Na etapa seguinte são estabelecidas as prioridades para recomendações da primeira etapa, são definidos os instrumentos de trabalho e é estabelecido e negociado um plano de ação. Essas são precisamente as atividades cobertas pela abordagem S:PLAN.

\section{6 - A abordagem Bootstrap}

No início de 1991, O ESPRIT (European Strategic Programme of Research in Information Technology), decidiu aplicar os questionários do SEI nas empresas desenvolvedoras de software européias. Montou-se uma equipe, a qual era formada por um grupo de empresas e institutos de pesquisa da Áustria, Bélgica, Finlândia, Alemanha e Itália. Ao finalizar o projeto de aplicação dos questionários do SEI havia-se construído uma nova abordagem, a qual foi denominada pelas empresas e institutos de Bootstrap (Haase, 1994).

A arquitetura da abordagem Bootstrap (Figura 2.5) é estruturada como uma árvore que identifica os Objetos, as principais Categorias de Áreas de Processo, as Áreas de Processo, os Processos e as Práticas Básicas, que são descritas a partir da perspectiva da unidade produtora de software e do projeto de software.

A categoria Metodologia é dividida em três principais áreas de processo (Haase, 1994):

- Funçסes relacionadas ao processo - contém as atividades de controle de processo e aspectos de descrição de processo. Foi baseada na Norma ISO 9000-3 e também no SW-CMM da SEI. Os processos incluídos nessas funções são: Descrição do Processo, Medida do Processo e Controle do Processo.

Dentro dessa área de processo é apresentada, entre outras coisas, quais atividades devem ser realizadas para a obtenção de um plano de ação. Essas atividades serão descritas no quarto capítulo dessa dissertação. 


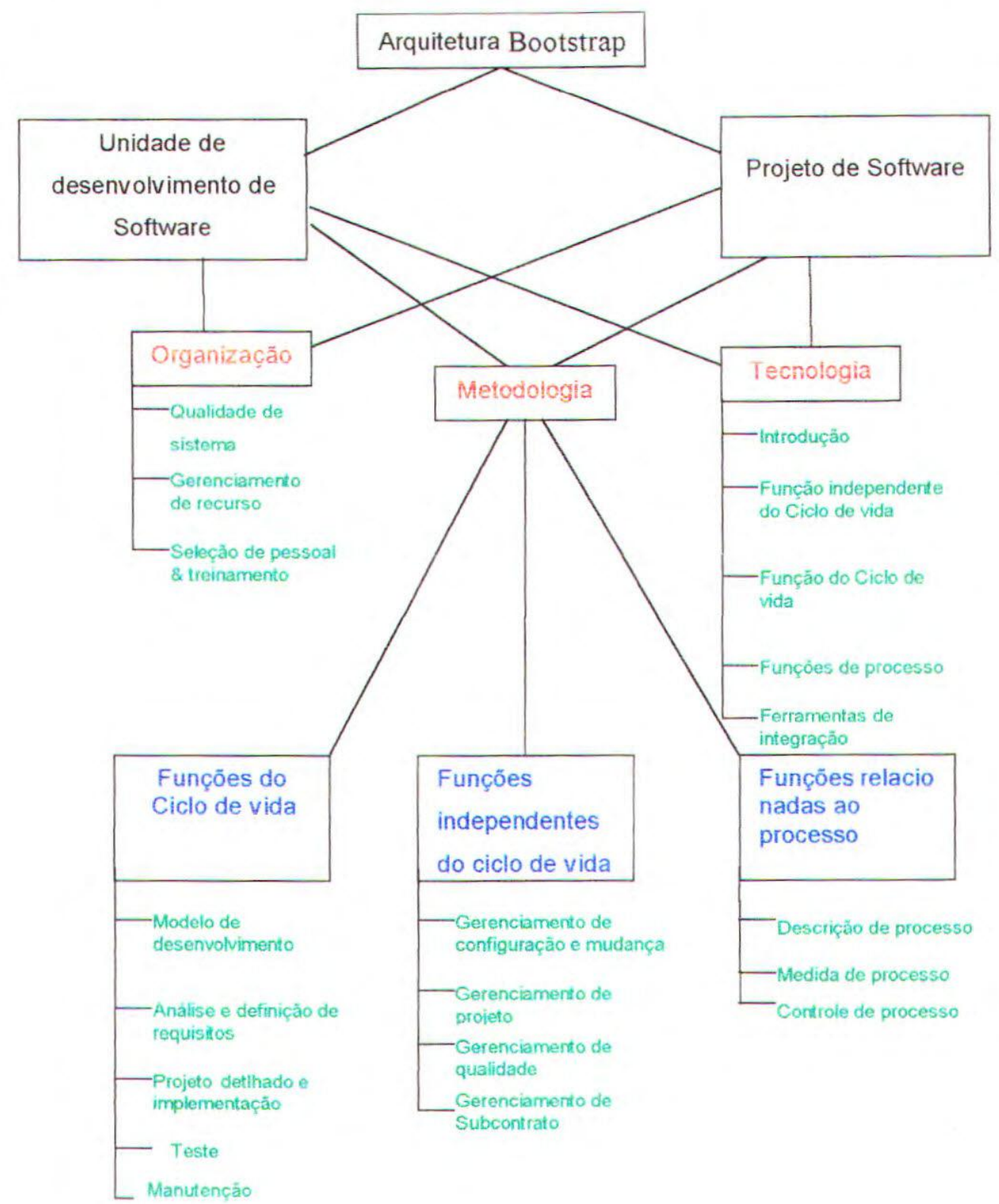

Figura 2.5 - Arquitetura da Abordagem Bootstrap (Kuvaja, 1994)

- Funções independentes do ciclo de vida - aplica as atividades que estão descritas na Norma ISO 9000-3 sob o título "Qualidade de Sistema - apoiando atividades". Os processo incluídos nessas funções são: Gerenciamento do Projeto, Gerenciamento da Qualidade, Gerenciamento de Risco, Gerenciamento de Configuração e Mudanças, Gerenciamento de Subcontratados. 
- Funções do ciclo de vida - segue o capítulo "Qualidade de Sistema - atividades do ciclo de vida", da Norma ISO 9000-3. Os processos incluídos nessa função são: Desenvolvimento do Modelo de Ciclo de Vida, Análise e Definição dos Requisitos, Projeto Arquitetural, Projeto Detalhado e Implementação, Teste, Operação e Manutenção.

A abordagem Bootstrap tem por objetivo determinar e apresentar um perfil da qualidade, tanto das organizações como de seus projetos. Essa abordagem identifica os pontos fortes e fracos do processo de software da organização, em seguida ajuda a montar um plano de ação para as melhorias a curto e longo prazo e a partir disso, a transformar o plano de ação em miniprojetos para a implementação das melhorias recomendadas (Kuvaja, 1994).

\section{4 - Considerações Finais}

Neste capitulo foram apresentadas algumas características das abordagens de melhoria de processo IDEAL, SPICE - parte7, S:PLAN e Bootstrap, situando, dentro de cada uma das abordagens, onde é considerado o desenvolvimento do plano de ação. Os detalhes do plano de ação dessas abordagens serão apresentados em detalhe no quarto capítulo dessa dissertação, devido a sua importância no contexto desse trabalho.

Como já mencionado anteriormente, antes de definir os passos para melhorar um processo de software, primeiramente, a organização deve realizar a avaliação desse processo. Um exemplo de avaliação de proçesso de software é através da Estratégia para Iniciar Melhoria de Processo de Software desenvolvida por Endo (1998). A estratégia de Endo será apresentada, resumidamente e somente a título de ilustração, no próximo capítulo. Será apresentado também um resumo do SW-CMM, explicando-se as seis KPAs do nivel dois desse modelo, uma vez que este é o nível considerado pela estratégia de Endo (1998). 


\section{Capítulo 3}

\section{Estratégia para Iniciar Melhoria de Processo de Software}

\section{1- Considerações Iniciais}

Segundo a abordagem IDEAL, os primeiros passos a serem executados para a realização de uma melhoria de processo de software são a Incialização e o Diagnóstico. Foi desenvolvida no ICMCUSP por Endo (Endo, 1998) uma Estratégia para Iniciar Melhoria de Processo de Software em Empresas de Pequeno Porte, a qual cobre os dois primeiros passos da abordagem IDEAL.

A título de ilustração de Avaliação de Processo de Software, neste capítulo é apresentado um resumo da Estratégia para Iniciar Melhoria de Processo de Software, desenvolvida por Endo (1998). A seguir, apresenta-se brevemente o SW-CMM, enfatizando-se as seis áreas-chave de processo do nível dois desse modelo, uma vez que esse é o nível desejado pela Estratégia proposta por Endo (1998).

\section{2- Estratégia para Iniciar Melhoria de Processo de Software em Empresa de Pequeno Porte}

Existem muitas variáveis que podem influenciar o sucesso de uma avaliação, principalmente porque o processo de software que se avalia é um processo complexo e com vários elementos (pessoas, responsabilidades, ferramentas, etc). Para que uma avaliaçăo de processo de software seja realizada de maneira organizada e controlada, é preciso que seja desenvolvido um planejamento de tal avaliação, considerando-se todos os elementos envolvidos. 
Com o objetivo de auxiliar a avaliação de processo de software, foi deseṇvolvido em 1998 , no ICMC/USP - São Carlos, um trabalho de mestrado que apresenta uma estratégia para avaliaçăo de processo de software. Esse trabalho toma como base a abordagem IDEAL, definindo, relacionando e organizando as principais atividades que devem ser realizadas para o cumprimento das fases de inicializaçăo e de diagnóstico, dentro de um programa de melhoria de processo de software para empresas de pequeno porte, tomando como base o rivel dois do SWCMM (Endo, 1998).

$\mathrm{Na}$ fase de inicialização da estratégia de melhoria de processo de software deve-se articular, claramente, a aplicação dos esforços para satisfazer as necessidades de negócio, devese assegurar o suporte ao gerenciamento e deve-se, finalmente, colocar em prática uma infraestrutura para gerenciar os detalhes de implementação do processo de melhoria. Ela é firmada em três pontos:

- Estímulo para mudança: são definidas as necessidades de negócio que alavancam as mudanças nas práticas da organizaçäo. Os estímulos para mudanças podem ser: um evento inesperado ou uma circunstância, uma ordem de alguém superior ou informaçőes obtidas por uma atividade de "benchmarking". Em geral, quando as necessidades de mudanças săo evidenciadas por razões dé negócio é mais fácil convencer a organização, como um todo, e existem maiores chances de sucesso.

- Estabelecer Contexto: após estarem definidas, claramente, as razões para a melhoria, a gerência da organização pode estabelecer o contexto para o trabalho que vai ser realizado. Isso significa definir, claramente, aonde os esforços vão se enquadrar na estratégia de nềgócio da organização, que metas e objetivos de negócio serão afetados pelas mudanças, como isso vai incidir sobre outras iniciativas e trabalhos futuros, e que benefícios são esperados. O contexto e as implicaçőes se tomarão mais evidentes à medida que o processo de melhoria seja encaminhado, mas é importante que essas questões estejam definidas, de maneira mais clara possivel, antes de iniciar os esforços.

- Definir Patrocinador. um patrocinador efetivo é um dos fatores mais importantes para os esforços de melhoria de processo. O patrocinador deve ajudar a manter o compromisso nos momentos de dificuldades e principalmente na situação de caos que a organização pode se encontrar no princípio do processo de melhoria. Outra função do pațrocinador é garantir os recursos essenciais utilizados durante a melhoria. 
A fase de diagnóstico da estratégia de melhoria de processo dẹ software caracteriza-se por dois estados da organização: um que representa o estado atual e outro que representa o estado futuro desejado. Para se verificar o estado atual do processo, é necessário que seja realizạa ụma avaliaçăo do mesmo. A avaliação de.processo significa capturar informaçōes que descrevam a capacidade real do processo de uma organização e é motivada pelo desejo de determinar ou melhorar a capacidade desse processo. Os pontos fracos, obtidos através da avaliação, são utilizados para priorizar as atividades que devem ser melhoradas, e os pontos fortes podem ser mantidos ou adaptados.

A estratégia de Endo (1998) culmina em um plano de ação que auxilia na elaboração e na condução das atividades que compõem a fase de diagnóstico, dentro do contexto de melhoria de processo de software de uma empresa de pequeno porte.

O plano de avaliação desenvolvido por Endo (1998) baseia-se nas diretrizes propostas pelo SEl para auxiliar na criação de um plano de açăo baseado no SW-CMM. Essas diretrizes estão contidas em um documento denominado CAF (CMM Appraisal Framework) (Dunaway, 1996)

O CAF é um documento que identifica os requisitos e as características desejáveis de uma avaliação, e ainda, melhora a consistência e a confiabilidade dos métodos de avaliação e dos seus resultados. Ele fomece um modelo para medir a maturidade do processo de uma organização em relação ao modelo de referência através de um método de avaliaçăo. Esse modelo contém três fases:

- Planejamento e Preparação para a Avaliação: essa fase deve cobrir as atividạdes de Identificação do Alcance da Avaliação, de Seleção e Preparação da Equipe Avaliadora, de Desenvolvimento do Plano de Avaliação e de Seleção e Preparação dos Participantes.

- Condução da Avaliação: as atividades de Coleta e Gravação de Dados, de Consolidação e Validação dos Dados e de Realização do Julgamento das Medidas são realizadas nessa fase.

- Reporte dos Resultados: essa fase envolve as ativida des de reporte dos Resultados da Avaliação, de Proteção das Informações Confidenciais e de Preservação das Gravações.

Além de propor um plano de avaliação do processo de software, Endo (1998) também elaborou um questionário, utilizado como instrumento de coleta de dados. Esse questionário 
abrange questões rèlacionadas as KPAs do nivel dois do SW-CMM. A organização dessas questões no instrumiento de avaliação foi baseada na estrutura do SW-CMM, mais especificamente na característica comum denominada "Atividades Realizadas", uma vez que, essas são responsáveis pelas atividades de implementação do processo de software.

\section{3- O SW-CMM - Software-Capability Maturity Model}

O SW-CMM, desenvolvido pelo SEl, é um modelo que apóia a melhoria do processo de software de uma organização através da aplicação criteriosa de conceitos de gerenciamento de processo e de melhoria de qualidade do desenvolvimento e manutenção (Marciniat, 1994), seguindo a abordagem IDEAL.

O SW-CMM classifica as organizações em cinco niveis diferentes. O nível de classificação, indica o conjuntos de atividades, denominadas áreas-chave de processo, que uma organização cumpre em cada nivel. Em cada um dos cinco níveis de maturidade (Inicial, Repetível, Definido, Gerenciado e Otimizado) são focalizados aspectos específicos do processo de software. No primeiro nível o focio está na coragem e na competência das pessoas. No segundo nível o foco eśtá no processo de gerenciamento de projetos. No terceiro nível, o foco está no processo de engenharia e suporte organizacional. No quarto nível o foco está na qualidade de produto e de processo. Finalmente, no quinto nível o foco é o processo de melhoria contínua. Alcançar cada nivel de maturidade significa estabelecer um componente diferente no processo de software, resultando em um incremento na qualidade do processo da organização. Segundo o modelo definido pelo SW-CMM, mesmo depois de ter obtido o quinto nível, a organização ainda permanece em um programa de melhoria contínua de processo (Paulk et al, 1993).

'Exceto no primeiro nivel, todos os outros niveis são subdivididos em KPAs. Essas KPAs são atividades relacionadas entre si, as quais a organização deve focar para melhorar o seu processo de software. Para que uma organização atinja um determinado nivel de maturidade do SW-CMM, ele deve realizar completamente todos'os processo relacionados as KPAs daquele nível.

\section{4- O Nível dois do SW-CMM - Repetível}

Nesse nivel do SW-CMM são estabelecidas politicas para implantar e gerenciar um projeto de software. O planejamento e gerenciamento de novos projetos são baseados no sucesso de projetos semelhantes anteriores. Um dos objetivos alcançados nesse nível é a institucionalização de um processo de gerenciamento efetivo para projetos de software, o que permite às organizações repetirem o sucesso de práticas desenvolvidas em projetos anteriores, embora 
processos específicos possam diferir entre si. Um processo efetivo pode ser caracterizado como um processo praticado, documentado, obrigatório, treinado, medido e capaz de ser melhorado. .

I nivel dois do SW-CMM possui seis KPAs, as quais são apresentadas a seguir:

\section{A) Gerenciamento de Requisitos}

A firralidade dessa área-chave é estabelecer um entendimento comum entre cliente e a equipe do projeto, sobre os requisitos do software que serão abordados. Isso envolve documentar e cortrolar os requisitos do cliente e manter os planos, produtos e atividades consistentes com esses requisitos. Um "cliente" pode ser interpretado como um grupo de engenharia de sistemas, um grupo de marketing, uma outra organização externa ou mesmo um cilente extemo. Esse entendimento deve envolver tanto os requisitos técnicos como não-técnicos (por exemplo, a data de entrega). Ele forma a base para o estímulo, planejamento, execução e avaliação das atividades através do ciclo de vida do software.

A alocação dos requisitos de sistema para software, hardware e outros componentes do sistema (por exemplo, recursos humanos) podem ser executados por um grupo externo ao grupo de engeriharia de software, e o grupo de engenharia de software rão pode ter controle sobre o primeiro. Dentro das diretrizes do projeto, o grupo de engenharia de software decide os pașsos a serem seguidos para assegurar que os requisitos de sistema alocados ao software são documentados e controlados.

Para conseguir isso, o grupo de engenharia de software faz revisóes dos requisitos de sistema alocados ao software para identificar e resolver problemas antes que eles sejam incorporados ao projeto de software. Sempre que os requisitos de sistema alocados ao software são alterados, os planos, produtos de trabalho e atividades de software afetados são ajustados para permanecerem consistentes com as alterações realizadas.

Assim, as duas metas dessa área-chave de processo são:

- Controlar os requisitos do software através de uma liriha de referência (baselịne) para o uso na engenharia de software e no gerenciamento.

- Manter os planos de software, produtos e atividades consisterites com os requisitos do software.

\section{B) Planejamento de Projeto de Software}


A finalidade dessa área-chave é estabelecer planos razoáveis para deserivolver e gerenciar o processo de software. Isso envolve desenvolver estimativas, determinar os compromissos e definir um plano para realizar o trabalho.

Esse plano inicia-se com a definiçäo do trabalho a ser executado e de outras diretrizes e objetivos que definem e delineiam o projeto de software (objetivos esses estabelecidos pela áreachave anterior). O plano inclui estimativa do tamanho dos produtos de software e também dos recursos necessários, elaboração de um cronograma, identificação e avaliaçăo dos riscos, e estabelecimento de compromissos. A iteração através desses passos pode ser necessária para estabelecer o plano para o projeto de software.

Este plano apresenta as bases para execução e gerenciamento das atividades do projeto de software, e atribui os compromissos para com os cliertes de acordo com os recursos, diretrizes e capacidades do projeto.

Assim, as três metas dessa área-chave são:

- Documentar as estimativas de software para serem utilizadas no planejamento e acompanhamento do projeto de software.

- Planejar e documentar as atividades de projeto de software e compromissos.

- Os grupos e os indivíduos envolvidos obedecerem aos seus compromissos relacionados ao projeto de software.

C) Visão Geral e Acompanhamento do Projeto

A finalidade dessa área-chave é oferecer visibilidade adequada do progresso real do projeto, para que a 'gerência possa tomar medidas efetivas quando o desempenho do projeto se desvia significativamente do plano. Isso envolve acompanhar e revisar os resultados e as realizações do software confrontando com as estimativas documentadas, compromissos e planos. Envolve, também, ajustar os planos com base nos resultados e realizações efetivamente alcançados. Os mecanismos utilizados são revisões intemas e revisões formais com clientes. Quando ocorre um desvio entre os planos e os resultados efetivos, deve-se alterar a forma como o trabalho está sendo feito e/ou ajustar os planos.

Assim, as três metas dessa área-chave são:

- Acompanhamerito dos resultados reais e desempenho do projeto em relação ao plano de software. 
- Realizar e gerenciar as ações corretivas quando os resultados reais e o desempenho desviarem significativamente do plano de software. :

- As mudanças nos compromissos de software serem obedecidas pelos indivíduos e grupos envolvidos.

\section{D) Gerenciamento de Subcontratos de Software}

A finalidade dessa área-chave é selecionar fornecedores (que se responsabilizam por parte do trabalho) qualificados e gerenciá-łos eficazmente. Isso envolve selecionar o fornecedor, estabelecer compromissos, acompanhar e revisar o desempenho e os résultados obtidos. Essas práticas cobrem desde o gerenciamento (somente) do subcontrato de software até o gerenciamento de componentes do subcontrato, o que inclui software, hardware, e possivelmente outros componentes do sistema.

Na seleção e gerenciamento do fomecedọr são necessários documentos como: cláusula de contrato, requisitos do projeto, produtos a serem entregues, padrōes e procedimentos a serem seguidos. As atividades de planejamento, acompanhamento e supervisão dos subcontratados são executadas pelo subcontratante. O contratante garante que essas atividades são executadas corretamente e que os produtos de software gerados satisfazem seu critério de aceitação.

Assim, as quatro metas dessa área-chave são:

- O contratante selecionar os subcontratado de software qualificado.

- O contratante e o subcontratado de software concordarem com os compromissos de ambas as partes.

- Manutenção da comunicação entre o contratante e o subcontratado de software.

- Acompanhamento, pelo contratante, do resultado real e desempenho do subcontratado de software em relação aos seus compromissos.

\section{E) Garantia de Qualidade de Software}

A finalidade dessa área-chave é oferecer gerenciamento, com visibịilidade apropriada, do proçeșso que está sendo utilizado e dos produtos que estão sendo desenvolvidos. Isso envolve revisões e auditorias nos produtos de software e nas atividades para assegurar que estäo em conformidade com os padrões e procedimentos aplicados. Envolve também fomecer esses resultados para os gerentes envolvidos. 
Assim, as quatro metas dessa área-chave são:

- Planejamento das atividades de garantia de qualidade de software-

- Verificação objetiva da conformidade dos produtos de software e atividades ao padrão aplicado, aos procedimentos e aos requisitos.

- Os grupos e indivíduos envolvidos serem informados sobre as atividades de garantia de qualidade e de seus resultados.

- Encaminhamento, ao gerente sênior, dos problemas de questões que não podem ser resolvidos no projeto de software.

\section{F) Gerenciamento de Configuraçăo de Software}

A finalidade dessa área-chave é estabelecer e manter a integridade dos produtos do projeto de software ao longo do ciclo de vida do software. Isso envolve identificar os itens de configuração, controlar sistematicamente as alterações e manter a integridade da configuração ao longo do ciclo de vida do software. O gerenciamento da configuração utiliza linhas de referência (baselines) que servem como um marco no ciclo de vida do software. Os itens que passam por uma linha de referência podem ser alterados somente através de procedimentos formais de controle de mudanças. Esta área-chave abrange as práticas para executar a função de gerenciamento de configuração de software.

Assim, as quatro metas dessa área-chave são:

- Planejamento das atividades de gerenciamento de configuração de software.

- Os produtos de trabalhos de software selecionados serem identificados, controlados e disponibilizados.

- Controle das mudanças em produtos de trabalhos de software identificados.

- Os grupos e indivíduos envolvidos serem informados sobre a situação e conteúdos das linhas de referências (baseline).

\section{5- Considerações Finais}

Neste capitulo foi brevemente apresentada, a título de ilustração, a Estratégia para Iniciar Melhoria de Processo de Software em Empresa de Pequeno Porte desenvolvida por Endo (Endo, 
1998). Apresentou-se também um resumo do SW-CMM e das áreas-chave do nivel dois desse modelo, uma vez que esse é o nível considerado pela Estratégia de Endo (1998).

No próximo capítulo apresenta-se o desenvolvimento do Plano de Ação das Abordagens de Melhoria de Processo de Software IDEAL, SPICE - parte.7, S:PLAN e Bootstrap, por serem essas as abordagens nas quais baseiam-se as Diretrizes de Estabelecimento de Melhoria de Processo de Software Adequada a Empresas de Pequeno Porte, propostas neste trabalho. 


\section{Capitulo 4}

Planos de Ação

\section{1 - Considerações Iniciais}

A fase de Estabelecimento da abordagem IDEAL é dividida em três passos (Estabelecimento de Prioridades, Desenvolvimento da Abordagem e Planejamento de Ações), culminando em um plano de ação. Visto que, o objetivo desse trabalho é propor Diretrizes para o Estabelecimento de Melhoria de Processo Adequada a Empresas de Pequerio Porte, foram estudados o desenvolvimento do plano de ação sob o porito de vista de quatro diferentes abordagens (a própria abordagem IDEAL, a abordagem da parte 7 do Modelo SPICE, a abordagem S:PLAN e a abordagem Bootstrap), para obtenção de informações.

As atividades a serem seguidas para o desenvolvimento do pları de ação segundo cada uma das abordagens citadas anteriormente serão apreseritadas nesse capítulo.

\section{2- Desenvolvimento do Plano de Ação segundo a Abordagem IDEAL}

Como já visto anteriormerite, a abordagem IDEAL é um acrōnimo que engloba cinco fases. A proposta da fase de Estabelecimento é desenvolver ou refirlar um plarıo de ação de melhoria de processo de software, o qual provê mudariças e direções para o programa de melhoria de processo de software nos próximos anos. O plano de ação é crítico e por isto é necessário prover direções claras para as várias ações de meihorla de processo a serem tomadas. 
Segundo a abordagem IDEAL, a melhoria do processo de software inicia-se determinando que tipo de planejamento de processo será seguido. Independentemente do método usado, é importante que seja desenvolvido um plano sólido.

O plano de ação deve ser baseado nos resultados dos esforços executados na fase de Diagnóstico da abordagem IDEAL, nos objetivos de melhoria da organização e nos recursos disponíveis. Isto deve prover a direção para o programa de melhoria de processo de software, definindo um longo alcance dos objetivos e endereçando como estes objetivos serão alcançados.

Experiências mostram que sem um cuidadoso planejamento, os esforços de melhoria desviam-se do objetivo a ser alcançado. A razão para o desenvolvimento do plano de ação rão é exatamente identificar as melhorias, mas encontrar as necessidades de negócios críticas da organização. A identificação das melhorias é freqüentemente a parte fácil, conseguir que todos da orgarização mudem o modo de pensar é sempre a parte mais difícil de qualquer esforço de melhoria.

O fluxo das atividades para o desenvolvimento do plano de ação segundo a Abordagem IDEAL é apresentado na Figura 4.1 e essas atividades são descritas a seguir.

\subsection{1- Selecionar e dar Treinamento em um Processo Estratégico de Planejamento}

O propósito desta atividade é escolher uma aproximação consistente para o planejamento da melhoria de processo de software e desenvolver habilidades em construir um planejamento sólido que sustente o programa de melhoria de processo de software.

Nesta fase é selecionado um processo de planejamento, além de ser treinada a equipe responsável por esse processo. Para passar para a próxima fase é necessário que a equipe responsável tenha completado o treinamento. É importante rever os métodos de planejamento em uso, rever as necessidades de planejamento para o programa de melhoria de processo de software, selecionar um processo de planejamento e obter um contrato para programar e organizar o planejamerito do treinamento. 


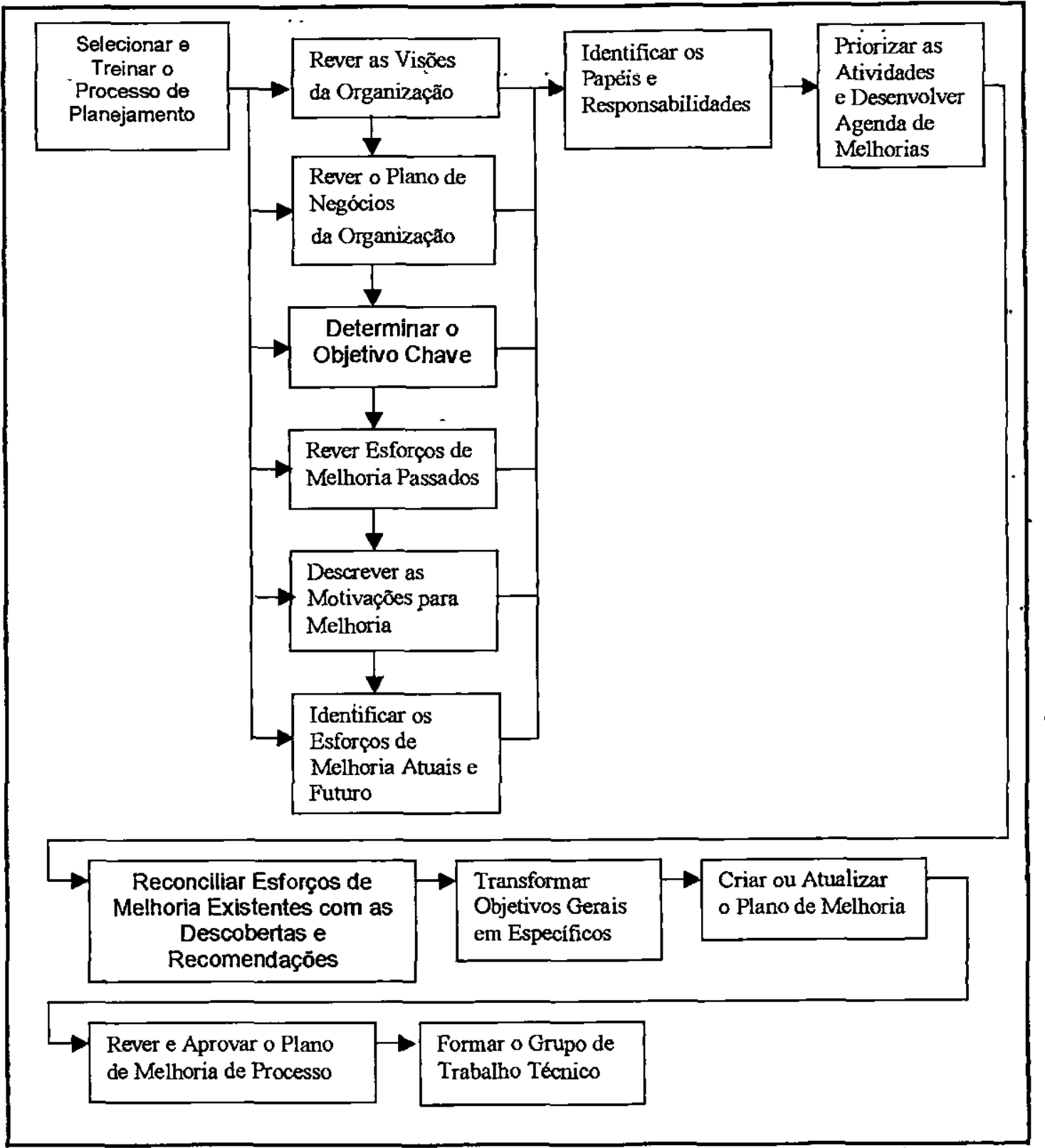

Figura 4.1- Fluxo para a Fase de Estabelecimento (IDEAL, 1999)

\subsection{2- Rever as Visões da Organização}

O propósito desta fase é unir a estratégia de melhoria de processo de software às visões e direções da organização, para que o programa de melhoria possa ser consistente com a direção de todas as atividades dentro da organização. 
Nesta fase é revista e possivelmente modificada a visão atual da organização, gera-se novas visőes se essa não existir ou se a que existir não for adequada, e identificam-se os objetivos e as motivações para o programa de melhoria de processo de software.

\subsection{3- Rever o Plano de Negócios da Organização}

Os objetivos desta fase são rever e possivelmente mudar o plano de negócios atual da orgarização, gerar novos plarıos de negócio se este não existir ou se o que existir for inadequado e identificar os objetivos e as outras iniciativas para a melhoria de processo.

Ao final desta são identificados os objetivos de melhoria de processo de software que é dirigido para os planos de negócio e outros esforços de melhoria que complementam o programa de melhoria de processo de software.

\subsection{4- Determinar o Objetivo Chave dos Negócios}

As melhorias devem ser selecionadas baseadas em parte nas suas habilidades de satisfazer as - necessidades de negócio.

As tarefas a serem realizadas nesta fase são rever os objetivos de negócios atuais a curto e longo prazo, como eles afetam a melhoria do processo de software e desenvolver critérios de priorização para selecionar e lançar projetos de melhoria de processo de software, baseados em parte nos objetivos de negócio identificados.

Ao final desta fase obtêm-se os objetivos de negócio claramente definidos e os critérios para priorização de projetos de melhoria de processo desenvolvidos.

\subsection{5- Rever os Esforços de Melhoria Passados}

As pessoas normalmente repetem comportamentos anteriores. A organizaçăo deve assegurar que pessoas repitam somente os comportamentos que conduziram ao sucesso. Os erros não devem ser repetidos para que não causem as mesmas negativas do passado.

O objetivo desta fase é rever mudanças passadas de melhoria e identificar práticas para alavancar o sucesso e práticas para evitar o insucesso.

As tarefas a serem cumpridas nesta fase são identificar práticas de sucesso e práticas de não sucesso, determinar o que fazer e definir estratégias para negociar com as tendências e barreiras identificadas no diagnóstico organizacional. 


\subsection{6 - Descrever as Motivaçőes para a Melhoria}

É importante que as pessoas entendam porque a organização gasta tempo e esforço no programa de melhoria de processo de software. Elas devem ser motivadas a trabalhar e ajudar. As motivações devem ser endereçadas aos seguintes pontos:

- Por que mudar?

- O que está errado com o estado atual?

- Por que eu devo me preocupar?

- Quando eu serei afetado (imediatamente ou somente no futuro)?

As tarefas a serem realizadas nesta fase envolvem a construção de uma lista de motivações dos objetivos e dos problemas identificados nos passos anteriores.

\subsection{7- Identificar os Esforços de Melhoria Atuais e Futuros}

As organizações possuem diferentes modos de realizar seus esforços para a melhoria do processo. A identificação das iniciativas de melhoria outras organizações pode ser bastante proveitosa.

O objetivo desta fase é identificar os esforços de melhoria existentes na organização ou em outras organizações.

\subsection{8- Identificar os Papéis e as Responsabilidades}

O objetivo desta fase é definir os papéis e as responsabilidades de cada pessoa dentro das atividades de melhoria de processo. Ao final desta fase os papéis e responsabilidades definidos devem ser aprovados e documentados.

\subsection{9- Priorizar as Atividades e Deserivolver uma Agenda de Melhorias}

O propósito desta fase é documentar publicamente uma aproximação objetiva para decidir qual das muitas recomendações de melhoria de processo de software serão executadas. Esta aproximação será dependente das necessidades de negócio da organização.

O objetivo desta fase é definir o critério para a seleção dos projetos da melhoria de processo de software. Ao finalizar esta fase o critério para seleção dos projetos é definido e documentado no plano de melhoria de processo de software. 


\subsubsection{0- Reconciliar os Esforços de Melhoria Existentes com as Descobertas e Recomendaçōes Armazenadas}

Os objetivos desta fase são incorporar as descobertas, obtidas nas fases anteriores, ao plano de ação de melhoria de processo de software e às outras atividades de melhoria de processo de software já existentes. Ao final desta fase obtêm-se uma estratégia coerente e única.

\subsubsection{1- Transformar os Objetivos de Melhoria de Processo de Software Gerais em Objetivos Mensuráveis e Específicos}

Após os resultados das atividades descobertas serem reconciliados, existirão dados disponiveis suficientes para compreender os objetivos gerais a longo e curto prazo e torná-los específico. Ao final desta fase obtêm-se os objetivos mensuráveis finalizados no plano de mèlhoria de processo de software.

\subsubsection{2- Criar ou Atualizar o Plano de Melhoria de Processo de Software}

Nesta fase o plano de açăo de melhoria de processo de software deve ser reconciliado com os resultados das decisões obtidas anteriormente. Os objetivos específicos da melhoria de processo e o plano de ação devem ser editados e finalizados. Como saída desta fase tem-se um plano de ação completo e escrito.

\subsubsection{3- Rever e Aprovar o Plano de Melhoria de Processo de Software}

O plano de ação não estará completo se possuir algum vazio e somente um pequerio grupo de pessoas acreditarem nele. Para ser útil ele deve ser sólido e deve ser obtido um consenso entre todas as pessoas envolvidas. O plano de ação de ação desenvolvido precisa ser comunicado às pessoas da organização.

As tarefas a serem realizadas nesta fase săo apresentar ou rever o plano de ação em todos os níveis da organização, coletar sugestões e resolver idéias conflitantes, incorporar todas as mudanças e conseguir que todos os gerentes aprovem o plano e enviar uma cópia do mesmo para todas as pessoas da organizaçăo envolvidas com o plano.

\subsubsection{4- Formar o Grupo de Trabalho Técnico}

O objetivo desta fase é montar uma equipe. A equipe deve ser composta de pessoas interessadas em trabalhar com melhoria de processo. Essas pessoas podem ser identificadas durante as fases 
de desenvolvimento do plano de ação de melhoria de processo de software. Ao final dessa fase tem-se a equipe de trabalho técnica estabelecida.

\section{3- Desenvolvimento do Plano de Ação segundo a Abordagem da parte 7 do Modelo SPICE}

Como já citado no segundo capítulo dessa dissertação, a parte 7 do Modelo SPICE apresenta um modelo de oito passos para melhorar o processo de software, dentro destes oito passos, o passo quatro destina-se a analisar os resultados da avaliação e derivar o plano de ação.

As informações coletadas durante a avaliação, são analisadas considerando-se as necessidades da organização para identificar as áreas para a melhoria, derivar um plano de ação e integrá-lo ao plano de programa de melhoria (caso esse exista).

A administração da organização deve aprovar as áreas para melhoria, as metas os objetivos, o plano de ação e o plano de programa de processo de melhoria revisado, comprometendo-se assim a empreender as melhorias planejadas. As decisões devem claramente comunicadas a todas as pessoas afetadas.

\subsection{1- Identificar e Priorizar as Áreas de Melhoria}

As áreas de melhoria devem ser identificadas e priorizadas baseadas em alguns fatores como mostrado na Figura 4.2

A) Análise dos Resultados da Avaliação

Análise dos resultados da avaliação provê informações sobre as forças e fraquezas atuais do processo e indica as oportunidades para melhoria.

Os pontos fracos podem ser um processo com um baixo nível de capacidade, um processo com falta de práticas bases necessárias para habilitá-lo a alcançar um propósito juntamente com uma necessidade específica da organização.

A variabilidade dos níveis de capacidade dos processos deve ser avaliada de acordo com o contexto do processo para identificar ações de melhoria específicas. Similarmente, devem ser comparados os níveis de capacidade de processos relacionados. 


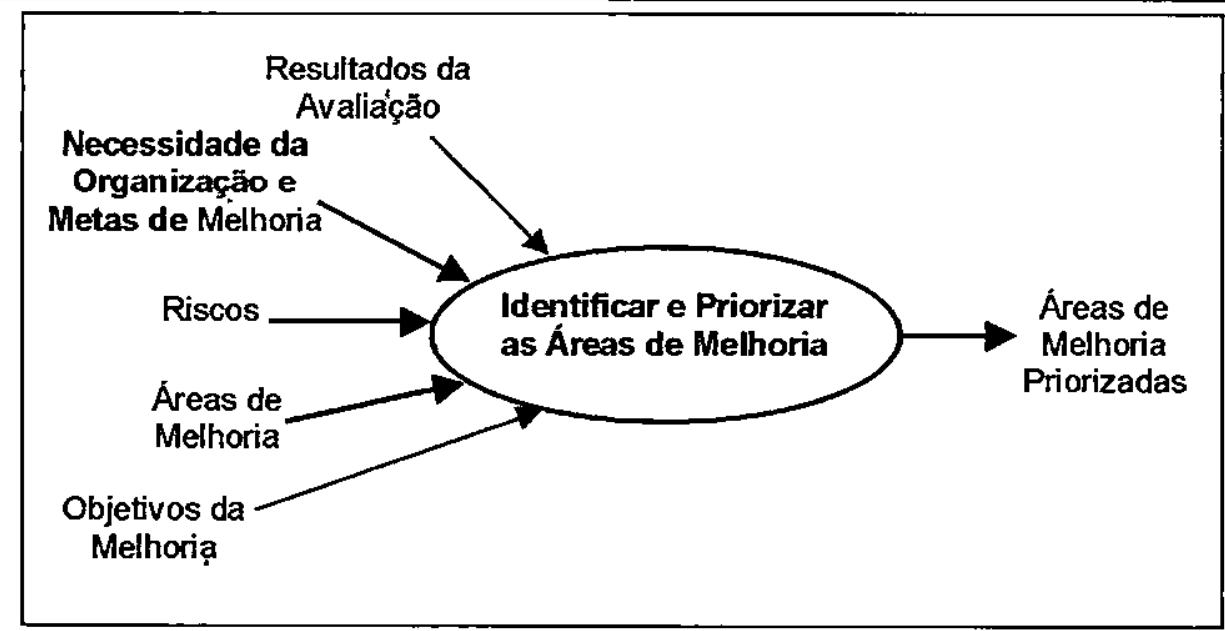

Figura 4.2- Identificaçăo e priorização das áreas de melhoria ( SPICE7, 1997)

B) Análise das Necessidades da Organizaçăo e Metas de Melhoria

As necessidades da organização podem derivar de uma análise dos objetivos de negócios da organização, de uma análise dos valores atuais da organização, de estímulos internos como declínio da satisfação do pessoal e de estímulo externos como mudanças competitivas no mercado ou novas exigências da sociedade.

Para uma análise das necessidades da organização e da existência de estimulos para meihoria, os objetivos da melhoria do processo devem ser identificados e descritos.

C) Análise dos Riscos de Fracasso das Ações de Melhoria

Os riscos potenciais de faiha de uma ação de melhoria devem ser analisados para suportar a definição de prioridades de melhoria e para assegurar o compromisso e o suporte organizacional. Estes riscos podem derivar da existência de constrangimento de horários, da existência de barreiras psicológicas ou culturais possivelmente derivadas de experiências anteriores, de fatores organizacionais que impedem o sucesso da execução de ações de melhoria.

D) Listar Áreas de Melhoria

A seleção das áreas de melhoria define o alcance das ações de meihoria a serem identificadas. Isso pode incluir os limites organizacionais para as melhorias e os processos a serem incluídos ou excluídos nas iniciativas de melhoria.

E) Definir os Objetivos da Melhoria 
Para definir os objetivos da melhoria, os principais passos são definir qualitativamente as métricas para cada área de prioridade, inventar métricas satisfatórias para médir a realização destas métricas e fixar valores apropriados para estas métricas, considerando os riscos.

\subsection{2 - Desenvolver o Plano de Ação}

O plano deve incluir dados históricos relevantes e o estado atual do processo, se possivel expresso em termos numéricos. Os objetivos de melhoria derivados das. necessidades da organização e dos objetivos de regócios provêm os principais requisitos para o plano. O plano deve conter todos os passo para a melhoria, é importante assegurar que os papéis estejam claramente identificados, que os recursos estejam alocados e que todos os riscos associados ao plano estejam identificados e documentados no mesmo.

O plano de ação de melhoria e o processo de programa de melhoria devem ser aprovados pela gerência para assegurar que a organização comprometa-se a implementa-lo.

\section{4- Desenvolvimento do Plano de Ação segundo a Abordagem S:PLAN}

A abordagem S:PLAN foi criada para ser uma cortiruação da avaliação S:PRIME, como uma forma de implementar as práticas selecionadas pela avaliação dentro da organização.. A abordagem S:PLAN consiste em uma série de entrevistas com pessoas da organização, onde se validam e priorizam os resultados da avaliação S:PRIME. Como entrada, a abordagem S:PLAN recebe os resultados da avaliação S:PRIME do processo de desenvolvimento ou manuterição do software dentro da organização. Como saida a abordagem S:PLAN gera um plano de ação com os detalhes de custos, responsabilidades e recursos erivolvidos (Vasquez, 1998).

A estrutura da abordagem S:PLAN é constituída por oito atividades, sendo quatro reuniões com as pessoas das organização e quatro atividades de preparação dessà reuniões, representadas por circunferências na Figura 4.3

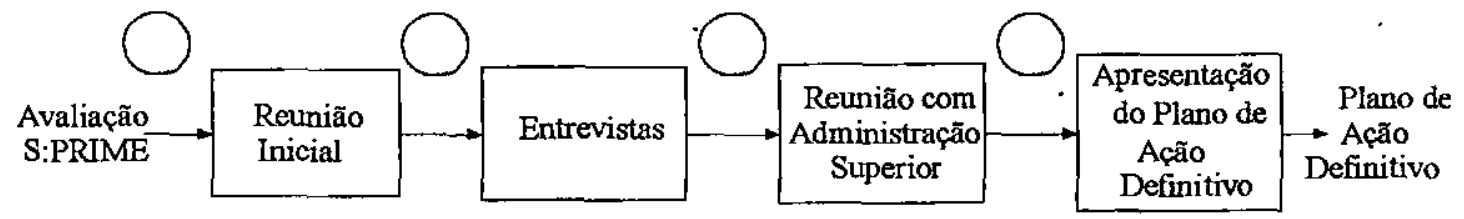

Figura 4.3 - Atividades que compōem a abordagem S:PLAN (Vasquez, 1998).

\subsection{1- Preparação da Abordagem}


A preparação da abordagem S:PLAN é a etapa onde se planeja a forma que se desenvolverá o planı de ação. Alguns aspectos sujeitos a considerações såo:

- Seleçăo dos participantes- participam das reuniões as mesmas pessoas que participaram da avaliação.

- Organizaçå das entrevistas - considerando que as entrevistas são um dos pontos principais da abordagem S:PLAN, elas requerem um planejamento e uma organização adequada. Por este motivo é estabelecida uma série de critérios para organizar e agrupar os participarites das entrevistas, com o objetivo de favorecer o trabalho em equipe. A abordagem considera os critérios a seguir para organizar e agrupar os participantes nas entrevistas:

- de acordo com o cargo que ocupam,

- de acordo com a área de desempenho.

- de acordo com os anos de serviço na organização e,

- de acordo com a experiência em outras orgarizações.

- Definiçăo dos papéis e das responsabilidades nas entrevistas - as entrevistas funcionam com um esquema de papéis, onde se determiria as responsabilidades específicas, as quais devem ser cumpridas pela pessoa designada. Os papéis necessários para uma entrevista são:

- Coordenador - pessoa que lidera a reunião e é resporisável pela forma em que a mesma se desenvolve.

- Secretánio - sua principal função é anotar as opiniōes e sugestões dós participantes em um formulário elaborado especialmente para tal propósito, o qual servirá posteriormente para a elaboração do Plano de Ação Prelimiriar.

- Participantes - são as pessoas integrantes da organização, as quais servirão de fonte de informação para o processo de realimentação sobre as práticas propostas para o Plano de Ação Preliminar.

A abordagem S:PLAN também considera a participação de papéis optativos, que são 0 Assessor de Melhoria de Processo e o Assessor dos Participantes, para os casos de reuniões extremamente complexas, onde os participantes não tenham uma noção çlara do que se pretende com a abordagem, ou para os casos onde os processos de negócios do interior da organização são bastante complexos, necessitando de um intermediánio entre os particlpantes e o coordenador. 
- Preparação de uma agenda de atividades - após organizar os grupos para as entrevistas, o passo seguinte é preparar a agenda de atividades, juntamente com o cliente. A agenda de atividades contempla todas as atividades que compõem a abordagem S:PLAN, com informações estabelecidas e definidas como a data de cada reunião, os detalhes das atividades a realizar, a duração estimada das reuniőes, o horánio de início e de término, o local, os participantes de cada reunião e os papéis designados a cada assistente.

- Preparação do material de trabalho - como última etapa, antes da reunião inicial preparase para cada participante uma cópla das práticas candidatas a implementar e os riscos observados na organização (as práticas e riscos foram selecionados na avaliação, através do Modelo S:PRIME). Estas cópias são denominadas "Folhas de Validação de .Riscos e Práticas", nas quais os participantes da Reunião Inicial priorizarão cada risco e cada prática, dando um indício sobre o conteúdo do plano de ação.

\subsection{2- Reunião Inicial}

A reuniăo inicial é dividida em três etapas:

- Apresentação dos resultados S:PRIME e da abordagem S:PLAN - apresenta-se os resultados da avaliação e explica-se os objetivos da abordagem S:PLAN, suas etapas e as vantagens de poder contar com um plano de ação.

- Preenchimento das Folhas de Validação - ao finalizar a apresentação distribui-se as folhas de validação e explica-se a forma correta de preenchê-las. Os participantes devem pontuar os riscos e as práticas das folhas de validação de acordo com seu critério, dando pontos mais altos para as práticas ou riscos que consideram mais importantes. Essas folhas são preenchidas com os objetivos de ordenar e reduzir a quantidade de práticas a implementar do total entregue pela avaliação S:PRIME e também para obter o apoio dos integrantes da organização.

- Apresentação da agenda aos participantes - na terceira etapa da Reunião Inicial apresenta-se a agenda de atividades a serem realizadas. O coordenador conversa com todos os participantes e a agenda pode sofrer algumas alterações.

\subsection{3- Preparação das Entrevistas}

A preparação das entrevistas é dividida em duas etapas: 
- Seleção das práticas e dos riscos - com as folhas de validação preenchidas, a assessor seleciona as práticas apropriadas para compreender os riscos que a organização está exposta. Primeiramente obtém-se um conjunto de riscos considerados importantes ou relevantes para a organização de acordo com a priorização dada pelos funcionários nas folhas de validação e com base nestes riscos escolhe-se um conjunto de práticas que abordem os riscos considerados.

- Preparaçáo do material - tendo selecionadas as práticas apropriadas, deve-se preparar o material a ser usado nas entrevistas. O material consiste em um registro de entrevistas, que permitem controlar cada reunião em termos da data, do horário de início e de término, dos assistentes, das áreas a que estes pertencem e dos papéis assumidos, um rascunho para entrevistas, onde se registram as práticas tratadas nas entrevistas e os guias para entrevistas ou checklist, que consistem em pautas com os pontos a considerar dentro de cada entrevista.

\subsection{4- Entrevistas}

As entrevistas são divididas em quatro fases:

- Reuniăo com os participantes - no inicio da entrevista são feitas as apresentações, o coordenador indica os objetivos da entrevista e as regras a serem seguidas pelos participantes. $A$ entrevista conta com uma pauta a seguir e algumas condições básicas para a sua realização, que assegurem o estabelecimento de um ambiente de trabalho agradável.

- Durante a entrevista - nesta fase é feita a leitura das práticas selecionadas das folhas de validação, entrega-se cópias das mesmas aos participantes e reserva-se alguns minutos para esclarecer dúvidas sobre conceitos não compreendidos. A seguir o coordenador começa a realizar as perguntas com respeito às práticas validadas e as respostas säo registradas no rascunho da entrevista.

- Fim da entrevista - a entrevista termina quando forem cobertos todos os tópicos planejados ou quando acabar o tempo máximo designado para a entrevista. Ao final da entrevista o coordenador faz um resumo da reunião, agradece a presença dos participantes e solicita uma breve opinião sobre a forma em que foi realizada a entrevista.

- Mudança de papéis - como a abordagem S:PLAN busca o conhecimento e a experiência a serem adquiridos pela organização, os papéis de coordenador e assessor são trocados quando já tiverem sido realizadas a metade das entrevistas. 


\section{4:4.5 - Preparação do Plano de Ação Preliminar}

A preparação do plano preliminar é dividida em quatro etapas:

- Revisăo do rascunho das entrevistas - as principais informações são obtidas através dos rascunhos da entrevistas. Tomando como base as informaçס̃es coletadas nas entrevistas, o coordenador juntamente com o assessor faz a estruturação do plano de ação preliminar.

- Estrutura do plano de açăo preliminar - o plano de ação preliminar conta com quatro pontos gerais: as práticas a implementar selecionadas das folhas de validação, os detalhes de implementação de cada prática como os recursos necessários, responsabilidades e esforços, as referências bibliográficas ou os modelos a serem seguidos para.cada área prática e um planejamento das tarefas a serem realizadas' para a aplicação das práticas em um projeto piloto.

- Referencias - são materiais de apoio para cada área prática. Estes materiais buscam suprir a falta de experiência ou conhecimento da organização, dentre eles estắo definições è guias para se realizar uma prática, modelos usados por outras organizações, etc.

- Planejamento - como parte final, o plano de ação preliminar inclui um planejamento elaborado com base nas estimativas de tempo, recursos e esforços obtidos pelas entrevistas. Isto é realizado através de uma Carta Gant que distribui o tempo das diferentes tarefas, por práticas que compõem o plano de ação preliminar.

\subsection{6- Reunião com a Administração Superior}

Após a elaboração do plano de ação preliminar organiza-se uma reunião para a apresentação do mesmo à administração superior da organização para sua revisão e aprovação. Participam desta reunião, além dos integrantes da administração superior, o coordenador e o assessor.

O objetivo desta reunião é negociar e acertar diretamente com a gerência da organização o conteúdo do plano de ação. Negocia-se aspectos importantes para a realização do plano, modificando os pontos considerados necessários.

\subsection{7- Preparação do Plano de Ação Definitivo}

Grande parte do plano de ação final já. foi elaborado na versão preliminar, o coordenador apenas pega os valores dos esforços, os nomes dos responsáveis e os prazos estimados de acordo com a administração da organização. Com essas mudanças o plano de ação preliminar transforma-se no plano de ação definitivo. 
Após o término do plano de açăo definitivo, o coordenador prepara uma cópia do plano para ser usada na apresentaçåo do mesmo e uma outra cópia para ser entregue ao assessor do S:PLAN.

\subsection{8- Apresentação do Plano de Ação Definitivo}

Nesta etapa o coordenador convoca todos os participantes do processo de desenvolvimento do S:PLAN, incluindo a administração e o assessor. O plano de ação é lido e explicado a todos os participantes. No final, informa-se aos presentes onde estará publicado ou arquivado o plano de ação, para o uso em projetos futuros.

Dentro da mesma-reunião inicia-se a forma de começar a aplicação do plano, o prazo de início estimado, a identificação ou perfil do projeto piloto a usar. Ao finalizar a reunião se dará por iniciada a etapa de implementação do plano de açăo definitivo, em um ou vános projetos pilotos, com uma data de início conhecida por todos.

\section{5- Desenvolvimento do Plano de Ação segundo a Abordagem Bootstrap}

Criar o plaño de ação é uma das iniciativas mais críticas na meihona de processo de software, e freqüentemente a mais abandonada. Na Abordagem Bootstrap o desenvolvimento do plano de ação é dingido de acordo com as decisões da avaliação e considera os objetivos de negócios específicos da organização para identificar as oportunidades de meihoria e para priorizar as ações de melhoria. É necessário um bom suporte organizacional para assegurar o sucesșo das ações de meihoria que foram selecionadas. Os niscos de melhoria devem ser considerados para que as ações corretas possam ser empreendidas e as faihas potenciais possam ser evitadas.

As principais atividades do desenvolvimento do plano de açăo segundo a abordagem Bootstrap são apresentadas na Figura 4.4

\subsection{1 - Verificação dos Resultados da Avaliação.}

O plano de ação é gerado baseado nas decisões da avaliaçăo. É importante assegurar que essas decisões.sejam completas e aceitáveis para que o plano de ação possa ser gerado corretamente. Deve ser obtido um acordo entre a organização e os funcionários como um primeiro estágio da derivação do planıo de ação. Para obter este acordo é recomendado avaliar e analisar todos os dados gerais que teriham sido coletados na avaliaçăo. 


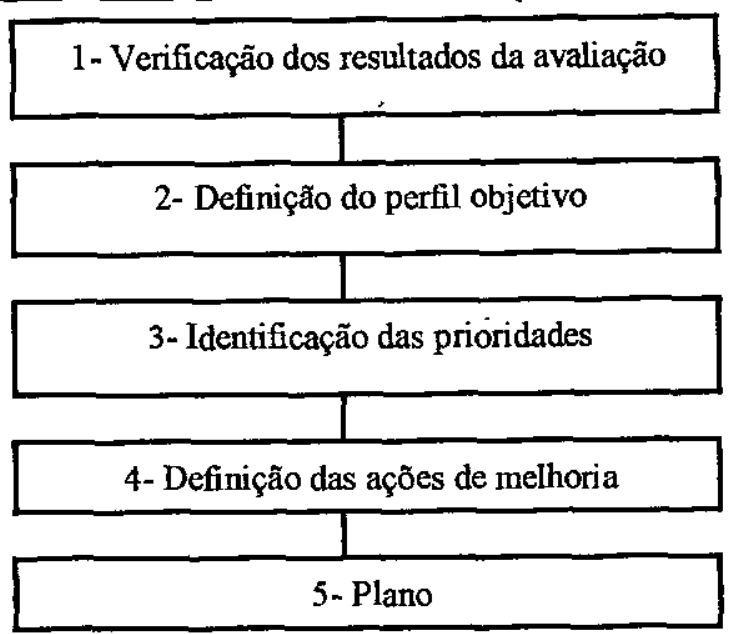

Figura 4.4- Atividades para o desenvolvimento do plano de ação (Kuvaja, 1994)

\subsection{2- Definição do Perfil Objetivo}

A definição do perfil objetivo fixa o nivel de maturidade objetivo e o perfil de capacidade objetivo da organização a ser obtido nos próximos passos da melhoria. O perfil objetivo é baseado na arquitetura de processo Bootstrap, onde a cada nivel de maturidade aumenta a necessidade do estabelecimento de um conjunto de processos bem identificados e práticas bem definidas dentro da arquitetura de processo.

\subsection{3- Identificação das Prioridades}

Freqüentemente acontece de uma organização não poder empreender todas as melhorias que foram sugeridas ao mesmo tempo, necessitando então priorizá-las. Alguns critérios para identificar as prioridades são:

\section{A) Identificar Áreas ou Processos Fracos}

Como ponto inicial, as áreas fracas podem ser identificadas realizarıdo-se uma análise entre o perfil de capacidade avaliado e o perfil de capacidade desejado. Um processo fraco é aquele que é pequeno em relação à capacidade desejada.

Quando os resultados mostram que os processos, os quais estão de acordo com o nível da organização, rão estão implementados nos projetos, devem ser encontradas respostas para as seguintes questões:

- Estes procedimentos são adequados para as necessidades?

- O pessoal está motivado e corretamente treirrado? 
- O compromisso da administraçăo é forte o suficiente?

Quando alguns projetos parecem estar melhor que a organização de um modo geral, algumas ações devem ser tomadas para alinhar toda a organizaçăo para as melhores práticas existentes nos melhores projetos.

\section{B) Considerar os Objetivos de Negócios da Organização}

As organizações iniciam as suas atividades de melhoria geralmente motivadas por razões como aumentar a satisfação do cliente, a competitividade ou o controle da produção, além dos objetivos de negócios, que podem ser considerados como a principal alavanca para a melhoria de processo.

O método de implementação da ação de melhoria depende de características e objetivos especificos de cada organização, como o tamanho da organização, a cultura, o mercado, etc. Entretanto os objetivos de negócios somente podem conduzir a um estabelecimento de melhores práticas de software e suportar a definição de prioridades quando organização é bem planejada.

C) Considerar Continuamente Iniciativas e/ou Requisitos da Organizaçăo

Como as atividades de melhoria são ainda recentes em orgariizações, as iniciativas similares devem ser consideradas. Por exemplo, é importarte saber antes de se iniciar uma ação de melhoria, os resultados de alguma experiência em outra organização. Essa irıformação pode auxiliar na obterıção de consciência e confiança das pessoas rıas ações de melhoria.

D) Considerar os Riscos de Melhoria

Ao se preparar um plano de ação, avalia-se a situação atual da organização para identificar riscos potenciais que podem comprometer o sucesso da melhoria. Esses riscos podem derivar de fracassos anteriores, da cultura existente, de recursos insuficientes, de um compromisso insuficiente com administração ou de uma melhoria inadequada para organização.

É importante analisar experiêrıcias similares, especialmente falhas, para prevenir problemas semelharites. Isto deve ser cuidadosamente considerado para que falhas anteriores nẫo tenham um efeito negativo na confiança das pesisoas relativo a melhoria. 
Uma melhoria de processo de software requer que o esforço e o tempo sejam identificados corretamente. O tempo deve ser avaliado para assegurar que os recursos requeridos estejam disponiveis. Recursos insuficientes podem comprometer a ação de melhoria. O compromisso com a administração deve ser forte o suficiente, pois uma mudança não pode ser implementada simplesmente por profissionais sem o apoio da alta administração. A ação de melhoria deve ser extremamente organizada, como qualquer outra atividade da organização.

\section{E) Considerar o Impacto das Açסes de Melhoria na Organizaçăo}

A análise do o impacto das ações de melhoria na organização ajuda ria identificação das prioridades e das iniciativas encorajadoras que podem aumentar a probabilidade de sucesso das principais mudanças. É necessário ter sempre em mente:

- Mudanças são difíceis e lentas e requerem um alto nível de investimento e de patrocínio inicial e contínuo,

- Apresentar desde o irí́cio o sucesso, pois mesmo que modesto ele reduz a resistência para mudarıças, aumenta a confiabilidade e facilita a transferência de tecnologia,

- Uma mudança organizacional é geralmente tão lenta quartto uma mudança metodológica,

- Se um papel for definido para uma atividade é desaconselhável iniçiar.essa atividade sem a pessoa que a administrará mais tarde.

\subsection{4- Definição das Ações de Melhoria}

Baseado em atividades anteriores, alguns objetivos de melhoria podem ser definiḍos. Os objetivos da melhoria devem ser bem definidos e as ações relacionadas a eles devem ser consideradas como projetos, os quais requerem uma organização correspondente. Assim deve ser assegurado:

- Identificar uma pessoa responsável para cada ação de melhoria,

- Identificar os recursos requisitados e verificar se eles estarão disporíveis durante todo o tempo necessário,

- Definir o carıal de informação.

\subsection{5- Plano de Ação}

Este passo indica o tempo para cada ação de melhoria que foi identificada e selecionada. Um programa em mais alto rível mostra o tempo escalado para todas as atividades de melhoria 
ideritificadas, um programa mais detalhado apreserta o tempo detalhado escalado para cada projeto de melhoria. Saídas e marcos intermediários também devem ser incluidos.

\section{6 - Considerações Finais}

Neste capitulo foram apresentados os planos de ação das abordagens de melhoria de processo de software IDEAL, SPICE parte 7, S:PLAN e Bootstrap.

No próximo capítulo serão apresentadas as Diretrizes para o Estabelecimento de Melhoria de Processo Adequada a Empresas de Pequeno Porte, propostas neste trabalho, as quais seguem os três passos da fase de Estabelecimento da abordagem IDEAL e consideram algumas idéias obtidas atrávés do estudo do desenvolvimento do plarıo de ação das quatro abordagens citarae antarinimante. 
Capítulo 5

\section{Diretrizes para o Estabelecimento de Melhoria de Processo Adequada a Empresas de Pequeno Porte}

\section{1 - Considerações Iniciais}

Este capítulo apresenta os três passos das Diretrizes para o Estabelecimento de Melhoria de Processo Adequada as Empresas de Pequerio Porte (Estabelecimento de Prioridades, Desenvolvimento da Abordagem e Planejamento de Açס̌es). Cada passo, bem como os elementos envolvidos, são explicados detalhadamente.

\section{2 - As Diretrizes de Estabelecimento de Melhoria de Processo}

Durante a fase de Diagnóstico da abordagem IDEAL, após a identificação do estado atual do processo de software da organização em relação ao estado futuro que se deseja alcançar, são desenvolvidas algumas recomendaçס̋es que serão utilizadas na fase de Estabelecimento.

Por exemplo, no estudo de caso apresentado por Endo (1998), existem algumas recomendaçठes que foram elaboradas a partir dos resultados apresentados nos gráficos gerados pela análise realizada (Figura 5.1 e 5.2).

Considerando-se o gráfico da Figura 5.1, observa-se que, no estudo de caso realizado por Endo (1998), a área-chave Garantia de Qualidade de Software apresentou-se deficiente no processo de software em questão. Para melhorar essa área chave é necessário existir um meio 
de garantir um controle de qualidade maior sobre o andamento do projeto, principalmente com relação às metas 1 e 2 que se referem respectivamente ao planejamento das atividades de garantia de qualidade de software e à verificação objetiva das conformidades dos produtos de software e das atividades ao padrão, aos procedimentos e aos requisitos aplicados.

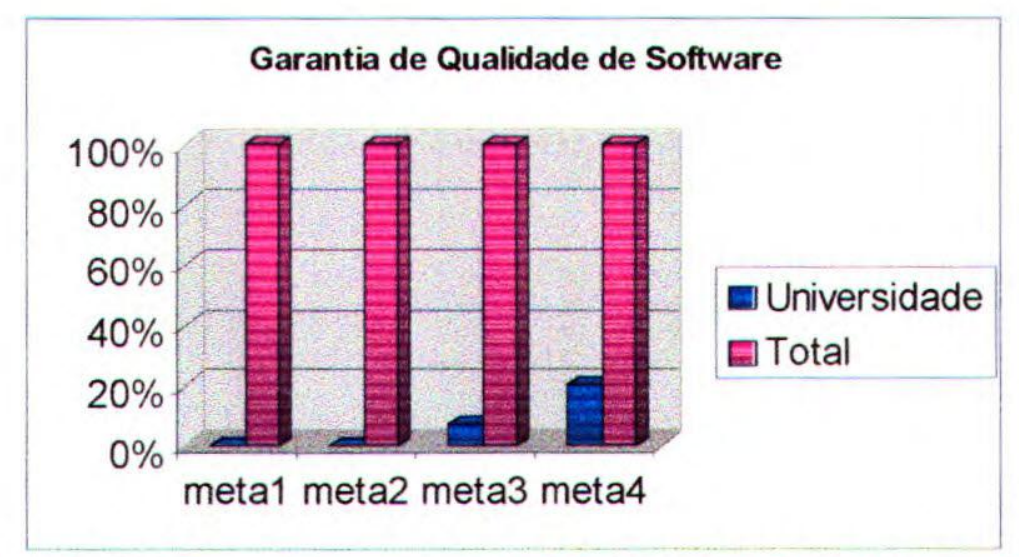

Figura 5.1: Informações sobre a área-chave Garantia de Qualidade de Software (Endo, 1998).

Observando-se o gráfico da Figura 5.2, nota-se que, no estudo de caso realizado por Endo (1998), a área-chave Gerenciamento de Configuração de Software encontra-se também deficiente. Para melhorar essa área chave devem existir planos, normas e procedimentos estabelecidos que evidenciem o cumprimento dessa atividade, principalmente com relação às metas 1 e 4 que se referem respectivamente ao planejamento das atividades de Gerenciamento de Configuração de Software e as informações transmitidas aos grupos e individuos envolvidos sobre a situação e conteúdos da configuração de software.

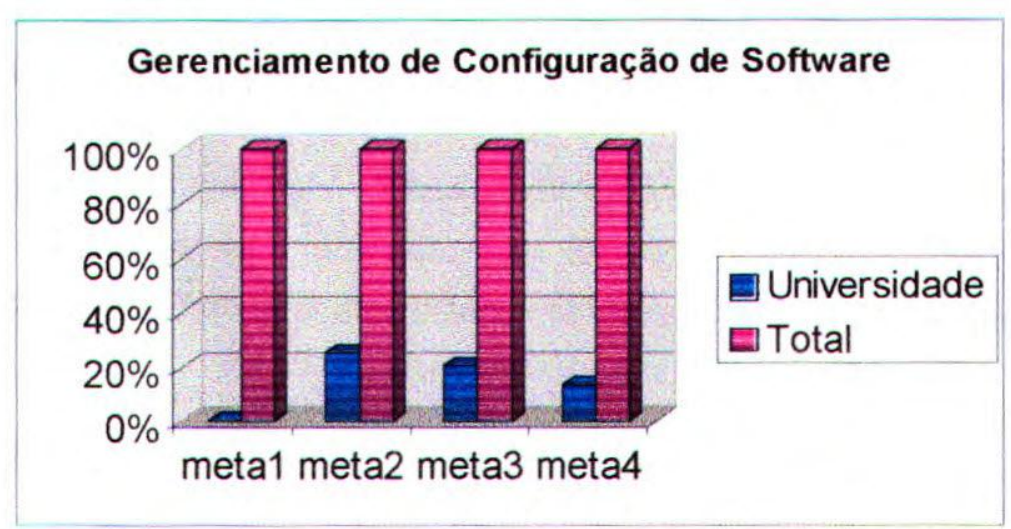

Figura 5.2: Informações sobre a área-chave Gerenciamento de Configuração de Software (Endo, 1998). 
Com base nas recomendações da fase de Diagnóstico, deve ser iniciada a fase de Estabelecimento de Melhoria de Processo de Software, a qual culminará em planos de ação de melhoria de processo de software.

As Diretrizes para o Estabelecimento de Melhoria de Processo de Software Adequada a Empresas de Pequeno Porte, propostas neste trabalho, seguem os três passos da fase de Estabelecimento da abordagem IDEAL (Figura 5.3), sendo que no passo 1 são utilizadas as recomendações produzidas na fase de Diagnóstico e no passo 2 são utilizados os resultados da avaliação produzidos nessa mesma fase.

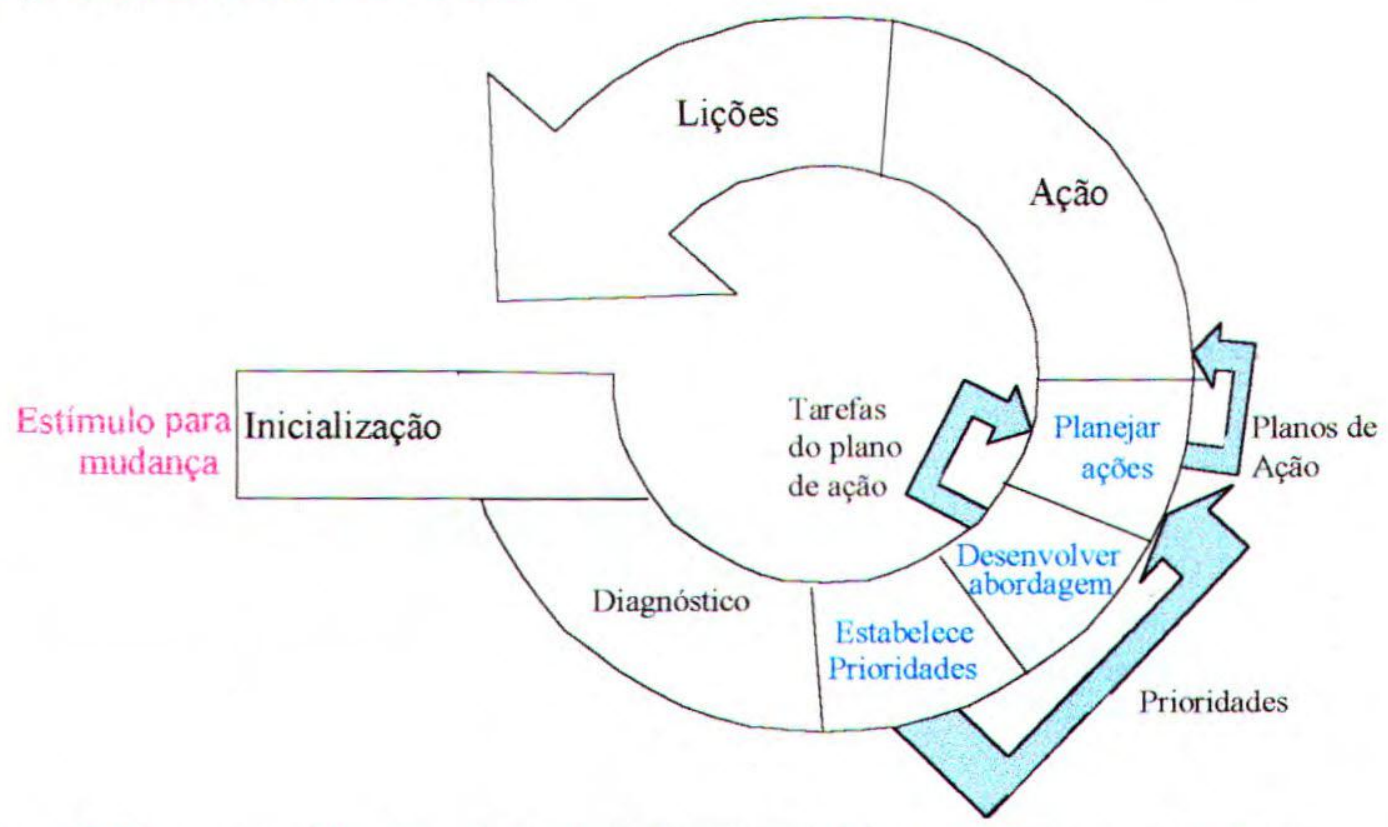

Figura 5.3 Passos das Diretrizes de Estabelecimento de Melhoria de Processo de Software.

Os planos de ação gerados mais as prioridades definidas na fase de Estabelecimento servirão como orientação para a fase de Ação da Estratégia de Melhoria quando então as tarefas apresentadas no plano serão efetivamente implementadas.

Para deixar mais claro como as Diretrizes devem ser aplicadas, considera-se neste trabalho (como exemplo) que o objetivo a ser atingido pela organização, com relação ao seu processo de software, seja o nivel dois do SW-CMM.

As Diretrizes são apresentadas a seguir, seguindo-se os três passos da fase de estabelecimento: Estabelecimento de Prioridades, Desenvolvimento da Abordagem e Planejamento de Ações. 


\section{3 - Passo 1 - Estabelecimento de Prioridades}

Seguindo-se as mesmas idéias da abordagem Bootstrap (Kuvaja, 1994) e da parte 7 do Modelo SPICE (SPICE7, 1997), estabeleceu-se que a determinação das prioridades deve ser uma decisão de consenso tomada pela gerência da organização. No entanto, neste trabalho, algumas informações são fornecidas para que a gerência da organização tenha mais condições de decidir a prioridade das atividades.

A priorização é apoiada em informações obtidas através da Análise dos Dados, dados esses coletados em uma reunião (Reunião para o Preenchimento do Questionário de PréCondições), na qual é apresentada uma Palestra (Palestra de Pré-Condições) e preenchido um Questionário (Questionário de Pré-Condições). A Reunião para o Preenchimento do Questionário de Pré-Condições é preparada antecipadamente (Preparação da Reunião para Preenchimento do Questionário de Pré-Condições), o que envolve o preenchimento do Plano para a Condução da Reunião de Pré-Condições (Figura 5.4).

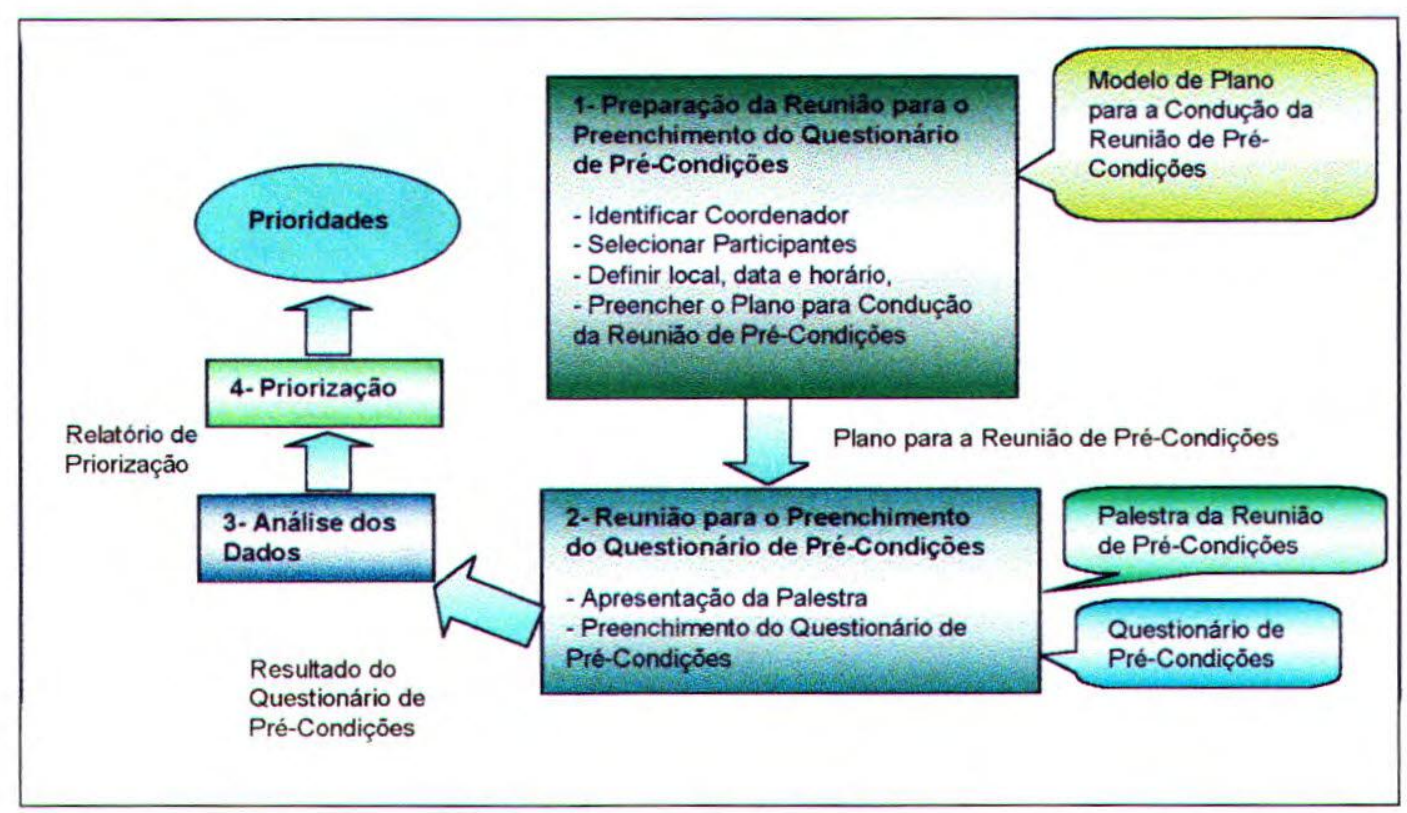

Figura 5.4- Estabelecimento de Prioridades

Antes da descrição das atividades para o estabelecimento das prioridades, apresentam-se os elementos envolvidos nessas atividades: o Modelo do Plano para a Condução da Reunião de Pré-Condições, a Palestra e o Questionário de pré-Condições. 


\subsection{1 - O Modelo do Plano para Condução da Reunião de Pré-Condições}

O Modelo do Plano para a Condução da Reunião de Pré-Condições estabelece um conteúdo mínimo necessário para definir as atividades e os requisitos necessários durante a reunião de précondições. O modelo de plano proposto neste trabalho (Esboço no Quadro 5.1) foi baseado nos planos desenvolvidos por Jubileu (1999). O modelo contém cinco seções:

1- Introdução - nessa seção é relatado o objetivo do plano,

2- Gerenciamento - nessa seção é identificado o local, a data, o horário de início e o horário de término da reunião, o nome do coordenador, os nomes dos participantes e a meta da reunião,

3- Tarefas - nessa seção são descritas as tarefas que serão realizadas na reunião de PréCondições. As principais tarefas a serem realizadas são a Apresentação da Palestra e o Preenchimento do Questionário de Pré-Condições.

- Apresentação da Palestra - para um correto preenchimento do Questionário de PréCondições, os participantes da reunião devem receber algumas informações. Essas informações são transmitidas através de uma palestra ministrada pelo coordenador da reunião.

- Preenchimento do Questionário de Pré-Condições - para descobrir as condições que a organização possui para implementar as áreas-chave de processo citadas nas recomendações no passo de avaliação, é respondido o Questionário de Pré-Condições.

4- Cronograma - nessa seção é descrito o tempo necessário para a realização de cada tarefa.

5- Recursos - nessa seção são descritos os recursos a serem utilizados.

\subsection{2 - A Palestra de Pré-Condições}

O objetivo da Palestra de Pré-Condições é apresentar aos participantes alguns conceitos que serão abordados no Questionário de Pré-Condições. Os slides da palestra encontram-se impressos no Apêndice $A$ e os tópicos cobertos envolvem:

- Melhoria do Processo de Software - apresenta-se uma breve explicação sobre melhoria de processo de software, enfatizando seus benefícios e pontos importantes, 
- Abordagem IDEAL - apresentam-se as fases da Abordagem IDEAL, enfatizando-se a Fase de Estabelecimento,

- Diretrizes para o Estabelecimento de Melhoria de Processo de Software - apresenta-se os passos das Diretrizes, enfatizando o fato de existir, no passo de Priorização, um Questionário (Questionário de Pré-Condições) que será preenchido pelos participantes da reunião após a apresentação da palestra,

- KPAs do nível dois do SW-CMM - apresenta-se a finalidade de cada uma das seis KPAs do nível dois do SW-CMM.

Como pode ser observado pelo cronograma da Figura 5.5, estima-se para a palestra um tempo de duração de 40 minutos, dos quais 35 minutos são usados para a apresentação e os 5 minutos finais para esclarecer dúvidas que ainda persistirem.

\begin{tabular}{|c|c|c|c|c|c|c|}
\hline Tópicos da Palestra & $5 \mathrm{~m}$ & $10 \mathrm{~m}$ & $15 \mathrm{~m}$ & $20 \mathrm{~m}$ & $25 \mathrm{~m}$ & $30 \mathrm{~min}$ \\
\hline \multicolumn{7}{|l|}{ Introdução } \\
\hline \multicolumn{7}{|l|}{ Melhoria de Processo } \\
\hline \multicolumn{7}{|l|}{ Abordagem IDEAL } \\
\hline \multicolumn{7}{|l|}{$\begin{array}{l}\text { Diretrizes para o } \\
\text { Estabelecimento de Melhoria } \\
\text { de Processo }\end{array}$} \\
\hline KPAs nivel dois do SW-CMM & & & & & & \\
\hline
\end{tabular}

Figura 5.5 - Cronograma da Palestra de Pré-Condições

\subsection{3 - O Questionário de Pré-Condições.}

Neste trabalho, considera-se que uma decisão de priorização deve levar em conta, entre outras informações, as condições que a organização possui para implementar as atividades (KPAs) citadas nas recomendações na etapa de avaliação da estratégia de melhoria de processo de software.

Para que descobrir essas condições, desenvolveu-se um questionário - O Questionário de Pré Condições - através do qual poderão ser obtidas informações importantes para a tomada de decisão de priorização. O questionário foi escolhido como instrumento de coleta de dados, por ser um meio simples de coleta e por sua aplicação poder ser realizada de maneira fácil e eficiente. 
Para a elaboração do Questionário de Pré-Condições, tomou-se como base as práticaschave consideradas na característica comum Habilidades para Realizar de cada KPA do SW$\mathrm{CMM}$, visto que elas representam as condições necessárias para a implementação eficaz do processo de software.

Os modelos SW-CMM possuem cinco características comuns (CMM/SEI, 1993):

1- Habilidades para Realizar: descrevem as pré-condiçöes que devem existir.no projeto ou na organização para que o processo de software seja implementado competentemente,

2- Atividades Realizadas: descrevem as atividades, papéis e procedimentos necessários para implementar uma área chave de processo,

3- Medições e análises: descrevem as necessidades para medir o processo e analisar as medidas. As medidas são usadas para melhorar e controlar o processo,

4- Verificaçăo da Implementaçăo: descrevem os passos para assegurar que as atividades sejam realizadas em conformidade com o processo que foi estabelecido,

5- Comprometimentos para Realizar: descrevem as ações que a organização deve tomar para assegurar que o processo seja estabelecido e que perdure.

A característica comum Habilidades para Realizar envolve tipicamente as práticas-chave estruturas organizacionais, recursos e fundos, treinamento e orientaçáo (Paulk et al., 1993):

- Estruturas Organizacionais: descrevem um tipo particular de estrutura organizacional, a qual apóia a KPA,

- Recursos e Fundos: refletem as necessidades de recursos e fundos adequados para as atividades cobertas pela KPA,

- Treinamento: é usado para tornar um indivíduo proficiente em uma prática especializada. Pode incluir tanto veículos informais quanto formais para transferir a habilidade e 0 conhecimento aos indivíduos na organização,

- Orientaçăo: o termo "orientação" é usado para indicar a transferência de uma habilidade ou conhecimento com menos profundidade do que seria esperada via treinamento. 
Quadro 5.1-Plano para a Condução da Reuniăo de Pré-Condiçőes

\section{PLANOPARA CONDUCAODARBUNUAO DE PRECOONDICÓES}

1- Introduca o o obetivo deste plano e ortentar o coordenador a conduzir a Reúnió de Pré condições.

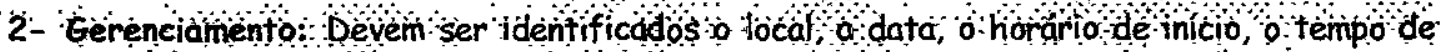
duracão o nome do coprdenador (o) e s nomes dos partjcipantes

Local da Reunião slocal físico onde ocorrerâ a reuniấo

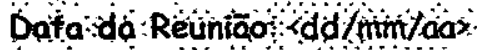

Horário de Início sthhlmm?

Tempo de duracóo ohh/min

Coordenador(a) nnomes

Participantes i nome dos participantes da rétinấos

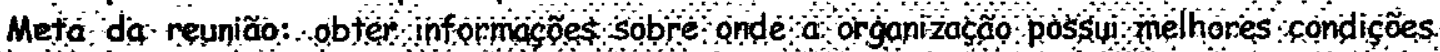
para in ciar a melthoria do processo de software.

3- Tapefas:

3.1- O codrderiador deve deixar claro o mótivo da participaçâ dé cada respondente

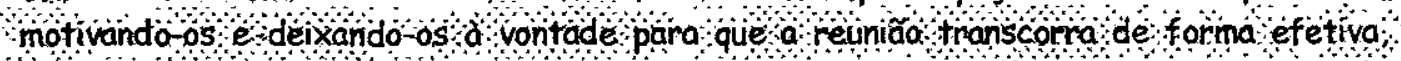
olém disso, deve deixar ctaro o seu papel

3.2- Apresentaço da Palestra - Nessa atividade deve sen opresentada una palestra que

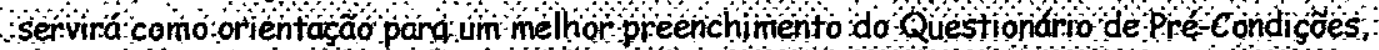

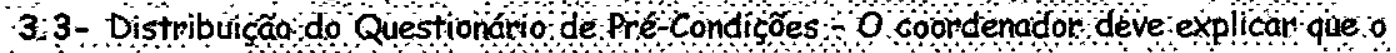

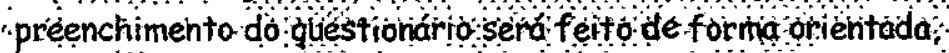

3.4- Preenchimento do Questionário de Pré-Condicones - $O$ coondenador deve ler $e$ explicar codo grupode prétond cóses separadantente

35- Recolhimento do Questionáro -0 coordenador deve recolher todos os qués tionário edgradecer a presencóde todos

4- cronograma deve ser estipulado um tempa para cada tarefo da reuniáo de PreCondiçốes:

5 - Reaursos o local selecionado para a reuniño deve ser isolado de quasquer outras pessons que não façam parte da reuniäo é itportante que os participantes näo sejam interrounidos

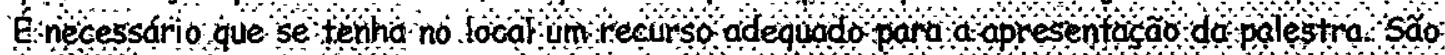
necessárias cadeiras e mesa, caso náo haja mesa sena utilizadas pranchetas que servirâa de apor para escrever e preciso que tod os os participantes possuam coneta para preencher o questionário e fażer as anótaçós gue désejar:

No Questionário (Apêndice B), as questões são divididas por KPA do SW-CMM. A cada KPA corresponde um conjunto de questões. Essas questões referem-se as práticas-chave da característica comum Habilidades para Realizar da KPA em questão. No início de cada KPA 
existe uma breve explicação do seu propósito e, quando necessário, existem exemplos. Ao se considerar, por exemplo, o nivel dois do SW-CMM, o questionário possui 25 questões. .

O questionário é endereçado aos desenvolvedores de software da organização e suas respostas auxiliarão a gerência na decisão de prionização.

\subsection{4 - Atividades para o Estabelecimento das Prioridades}

Apresentados os elementos envolvidos no estabelecimento das prioridades, apresenta-se a seguir as quatro atividades: a Preparaçăo da Reuniăo para o Preenchimento do Questionário de PréCondições, a Realizaçăo da Reuniăo para o Preenchimento do Questionário de Pré-Condiçōes, a Análise dos Dados e a Priorizaçăo.

\section{Atividade 1 - Preparação da Reunião para o Preenchimento do Questionário de Pré-Condições}

A reunião para o preenchimento do questionário de pré-condiçőes deve ser planejada antecipadamente. Isso envolve o preenchimento do plano para a condução da reuniắa-(Quadro 5.1), o qual servirá de orientação para o coordenador da reunião.

Para o preenchimento do plano para a conduçăo da reuniáo de prionizaçăo deve ser identificado antecipadamente o coordenador (o qual não precisa ser, neceš̉ariamente, funcionáno da organização) e selecionado os participantes da reunião (os quais devem ser funcionários da organização).

Identificação do coordenador: o coordenador é a pessoa responsável por liderar a reunião de priorização e a forma como essa reunião se desenvolverá, aiém de oferecer as orientações necessárias aos participantes (através da apresentação da Palestra de Pré-Condições), aplicaro questionário e validar as respostas. O coordenador deve ser capaz de combinar conhecimento, habilidade e experiências individuais apropriados, e também possuir coṇhecimento da estrutura do SW-CMM, das KPAs envolvidas no Questionário de Pré-Condições e do relacionamento entre essas KPAs.

Seleção dos participantes: segundo Vásquez (Vásquez, 1998), a seleção dos participantes deve considerar o cargo que ocupam e a área de desempenho.

A seleção dos participantes de acordo com o cargo que ocupam deve ser considerada para estabelecer um ambiente de trabalho onde não existam chefes e subaltemos, favorecendo a 
liberdade de expressão das pessoas. Ter em uma mesma sala chefes e subalternos pode gerar uma hierarquia involuntána, onde os subalternos não se sentem à vontade para fazerem críticas.

Com a seleção de acordo com a área de desempenho, pretende-se que todos os participantes tenham um mesmo nível de conhecimento.

\section{Atividade 2- Realizaçãó da Reuniáo para o Preenchimento do Questionário de Pré-Condições}

O objetivo da Reunião para o Preenchimento do Questionário de Pré-Condições é obter informações para auxiliar a gerência na decisão de prionização das atividades.

Considerando a reunião um ponto extremamente importante, devem ser considerados alguns fatores para a obtençăo de uma reunião proveitosa (Vásquez, 1998):

- Reservar antecipadamente o local da reunião. No caso do local reservado não se encontrar disponivel no momento da reunião, é necessánio contar com um lugar alternativo,

- . Contar com elementos necessários para a realizaçăo da reunião, como recursos audiovisuais para a apresentação da palestra,

- Os participantës devem estar acomodados, para isso devem existir tantas cadeiras quanto participantes,

- Comunicar antecipadamente o local, o horário de início e de término da reunião à todos os participantes.

No início da reunião o coordenador apresenta a palestra de orientação e após a apresentação reserva alguns minutos para sanarem as dúvidas que ainda existirem. A seguir o coordenador deve distribuir os questionários aos participantes e explicar' a forma correta de preenchimento. As três possiveis respostas para cada questão são: Sim, Năo e Năo Sei.

A resposta Sim deve ser assinalada quando a pré-condição existe.

A resposta Não deve ser assinada quando a pré-condição não existe.

A resposta Năo Sei deve ser assinalada quando o respondente não estiver seguro da resposta. 
Qualquer tipo de anotação em relação às questões pode ser acrescentada nos espaços reservados no fim de cada conjunto de questões. Todas as questöes devem ser respondidias assinalando apenas uma opção.

Após o preenchimento, o coordenador recolhe os questionários, agradece a presença dos participantes, destacando a colaboração de cada um para melhoria do processo de software da organizaçăo. Ao finalizar, o coordenador deve pedir aos participantes uma breve opinião sobre a forma como foi conduzida a reunião. Essas informações são importantes para orientarem outras reuniōes.

\section{Atividade 3 - A Análise dos Dados}

De posse dos questionários preenchidos, o coordenador deve fazer uma análise dos resultados obtidos através das repostas. Essa análise é feita separadamente para cada KPA, onde a KPA pode ser cumprida de 0 a 100 por cento, sendo que as suas questões são pontuadas individualmente. Por exemplo, considerando a KPA Gerenciamento de Requisitos, a qual possui quatro questões, cada questão vale $25 \%$ caso seja assinalada a opção Sim como resposta.

Considera-se que a KPA que a organização possui maiores condições de realizar é aquela KPA para a qual existam um número maior de pré-condições cumpridas, ou seja, a KPA que possua maior quantidade de respostas Sim no seu grupo de questões. O Quadro 5.2 apresenta 0 número total de pré-condições e o valor perceṇtual de cada pré-condição por KPA.

Feita a análise dos dados, o coordenador deve elaborar um Relatório (Relatório de Prioridades), o qual contém um gráfico dos resultados da análise e algumas recomendações. Esse relatório deve ser entregue à gerência da organização para auxiliar na decisão da escolha as atividades por onde iniciar a melhoria.

Quadro 5.2- Número de pré-condições e valor de cada pré-condlção por KPA

\begin{tabular}{|l|c|c|}
\hline \multicolumn{1}{|c|}{ KPA } & No de pré-condiçöes Valor percentual por pré-condição \\
\hline Gerenciamento de Requisitos & 4 & $25 \%$ \\
\hline Planejamento de Projeto de Software & 4 & $25 \%$ \\
\hline $\begin{array}{l}\text { Acompanhamento e Supervisão do } \\
\text { Projeto de Software }\end{array}$ & 5 & $20 \%$ \\
\hline $\begin{array}{l}\text { Gerenciamento de Subcontratados de } \\
\text { Software }\end{array}$ & 3 & $33,3 \%$ \\
\hline $\begin{array}{l}\text { Garantia de Qualidade de Software } \\
\text { Gerenciamento de Configuração de } \\
\text { Software }\end{array}$ & 4 & $25 \%$ \\
\hline
\end{tabular}

Um esboço do relatório Prionização é apresentado no Quadro 5.3 


\section{Atividade 4 - Priorização}

Segundo Kuvaja (Kuvaja,1994), uma decisão de priorizaçāo deve considerar os objetivos de negócio da organização.

O Relatório de Prioridades pode ser usado pela organização para orientar a decisão de priorização, porém a decisão deve ser tomada considerando os objetivos de negócio da organização.

De acordo com Furlan (Furlan, 1997), os objetivos de negócio envolvem quatro questōes básicas:

- Quem sou?

- Onde estou?

- Para onde irei?

- Como irei?

A questão "quem sou" visa a identificação própria. Neste momento a organização deve procurar o auto-conhecịmento.

A questão "onde estou" visa determinar o posicionamento atual da organização no mercado, incluindo uma análise de negócios e a verificação da efetividade dos sistemas atuais da organizaçăo.

A questão "para onde irei" visa determinar as expectativas dos executivos com relação ao futuro da organização, incluindo a sua participação no mercado e as necessidades adicionais de negócio.

Por fim, a questão "como irei" visa determinar os meios e recursos necessários para que a organização atinja os seus objetivos de curto, médio e longo prazo.

Estabelecidas as prioridades e dando continuidade às Diretrizes para o Estabelecimento de Melhoria de Processo de Software Adequada as Empresas de Pequeno Porte, no passo dois é apresentado o Desenvolvimento da Abordagem. 
Quadro 5.3 - Relatório de Prioridades

\section{Relatório de Prioridades}

Data: $<\mathrm{dd} / \mathrm{mm} / \mathrm{aa}>$

Organização: <nome>

Coordenador (a): <nome>

O gráfico abaixo apresenta informações obtidas através da análise dos resultados dos Questionários de Pré-Condições preenchidos pelos funcionários da organização.

Gráfico:

\section{Resultados das Pré-Condiçöes}

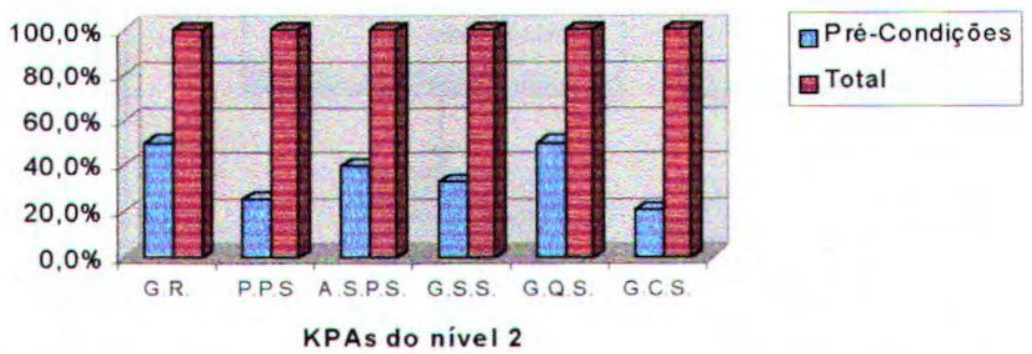

Observação: A decisão de Priorização , deve considerar, além dos resultados do gráfico, os objetivos de negócio da organização.

\section{4 - Passo 2 - Desenvolver Abordagem}

O desenvolvimento de uma abordagem para a realização do trabalho combina o conhecimento adquirido na fase de Diagnóstico com o conjunto de prioridades identificadas no passo 1 das Diretrizes.

O passo de desenvolvimento da abordagem (Figura 5.6) culmina em tarefas que serão inseridas no plano de ação elaborado no último passo das diretrizes.

As tarefas são determinadas para cada KPA do SW-CMM separadamente e baseiam-se em relatórios de dois tipos: o primeiro tipo de relatório (Relatório de Atividades) é elaborado considerando os resultados da avaliação do processo e o segundo tipo de relatório (Relatório de Pré-Condições) é elaborado considerando os resultados do questionário de pré-condições (aplicado no passo anterior das Diretrizes). Tanto os relatórios do primeiro tipo quanto os 
relatórios do segundo tipo podem ser desenvolvidos paralelamente uma vez que os dois tipos são independentes.

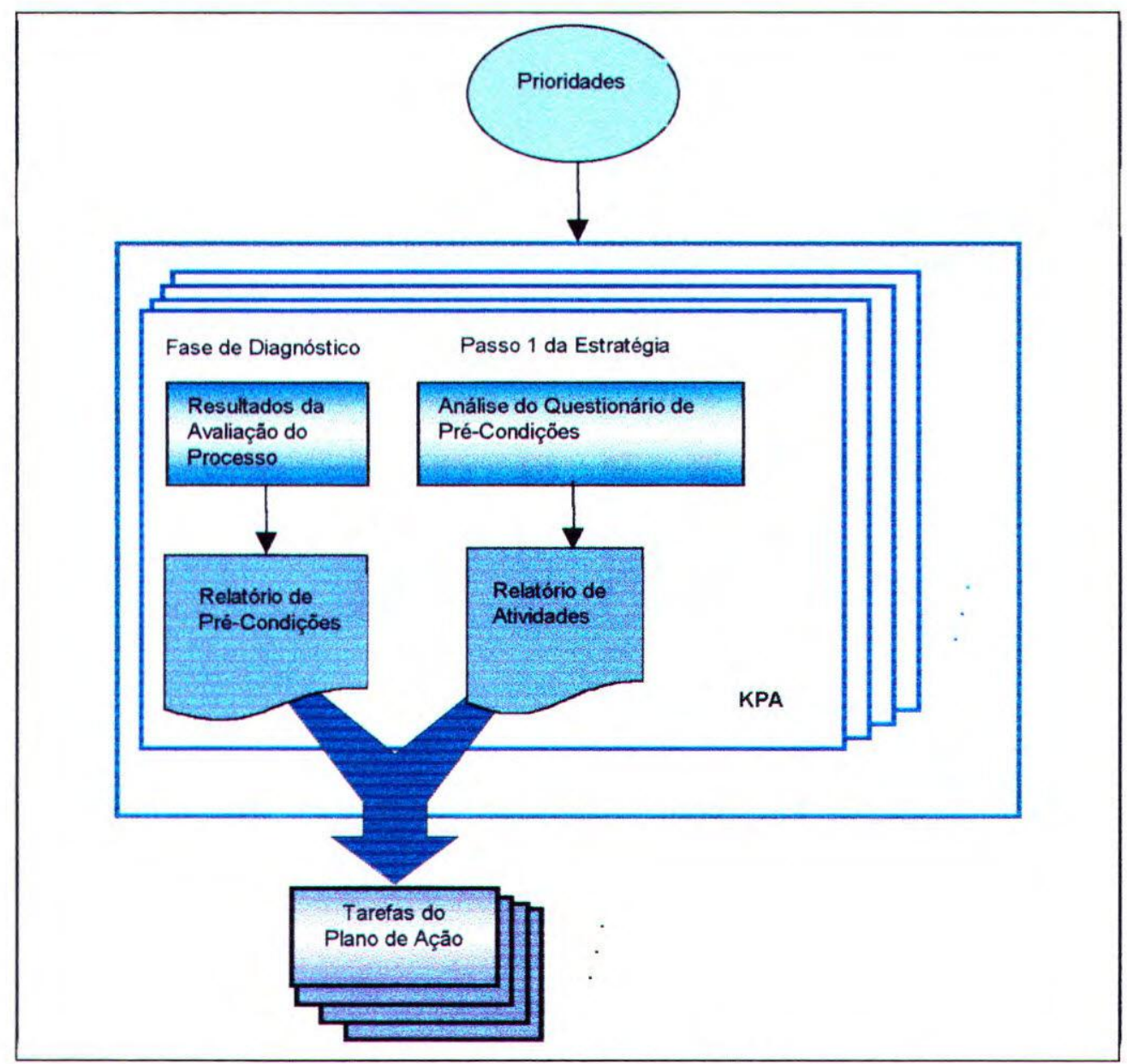

Figura 5.6 - Desenvolvimento da Abordagem

Os dois relatórios envolvidos no desenvolvimento da abordagem são descritos a seguir.

\subsection{1 - Relatório de Pré-condições}

O Relatório de Pré-Condições (Exemplo no Quadro 5.5) apresenta todas as tarefas que devem ser executadas para que as atividades de uma determinada KPA possam ser realizadas.

O Relatório de Pré-Condições é desenvolvido tomando-se como base as pré-condições de cada KPA que a organização não realiza, o que pode ser observado analisando-se o Questionário de Pré-Condições aplicado no passo 1 das Diretrizes. 
Por exemplo, considerando-se o Questionário de Pré-Condições (preenchido aleatoriamente) referente a KPA Gerenciamento de Requisitos (Quadro 5.4), obtém-se os Relatório de Pré-Condições do Quadro 5.5

Quadro 5.4 - KPA Gerenciamento de Requisitos do Questionário de Pré-Condições

\section{Gerenciamento de Requisitos}

1.1- Para cada projeto, são atribuídas responsabilidades para análise e documentação dos requisitos do sistema e a alocação desses requisitos para hardware, software e outros componentes do sistema?

Essas responsabilidades cobrem:

- Gerenciamento e documentação dos requisitos do sistema e sua alocaçăo através da vida do projeto.

- Administração das alteraçőes nos requisitos do sistema e na alocação dos requisitos.

1.2- Existem condiçőes para se documentar efetivamente os requisitos?

1.3- São providenciados recursos e fundos adequados para o gerenciamento dos requisitos?

Estes recursos e fundos cobrem:

- Pessoas com experiência e habilidade no domínio de aplicação e engenharia de software designadas a gerenciar os requisitos de software,

-Ferramentas de apoio, para atividades de gerenciamento de requisitos.

Exemplos de ferramentas incluem:

- programas de planilha eletrônica,

-ferramentas para o gerenciamento de configuração,

-ferramentas de acompanhamento e,

-ferramentas para o gerenciamento de testes.

1.4- É dado treinamento nas atividades de gerenciamento de requisitos para as pessoas ligadas Sim

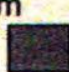

Não

Não sei ao desenvolvimento do software?

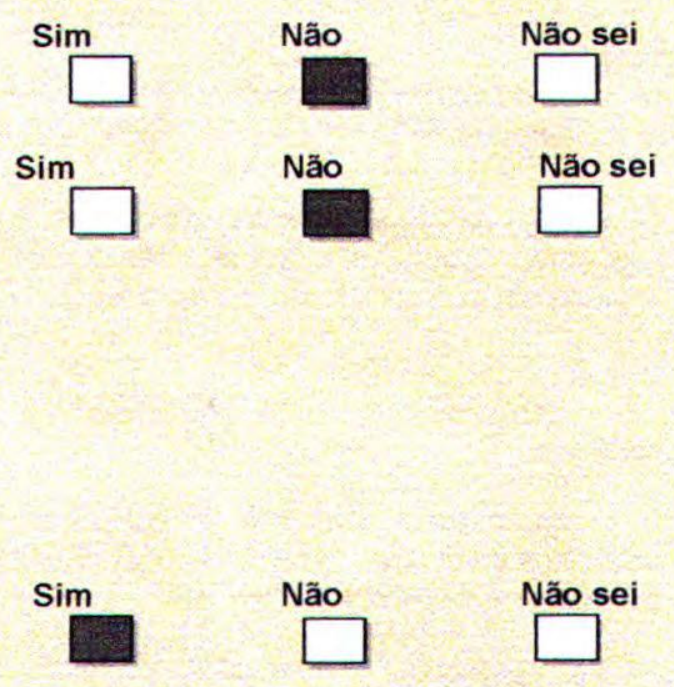

Quadro 5.5 - Relatório de Pré-Condições

\section{Relatório de Pré-Condições}

\section{KPA - Gerenciamento de Requisitos}

Tarefas:

1- Devem ser providenciadas condições para se documentar efetivamente os requisitos.

2- Devem ser providenciados recursos e fundos adequados para o gerenciamento dos requisitos. 


\subsection{2 - Relatório de Atividades}

O Relatório de Atividades (Exemplo no Quadro 5.7) apresenta as tarefas que devem ser executadas para o cumprimento de uma determinada KPA.

Esse relațório é desenvolvido tomando-se como base as atividades de cada KPA que não foram cumpridas pela organizaçăo, o que pode ser observado analisando-se o Questionário de Avaliação aplicado na fase de Diagnóstico da estratégia de melhoria de processo de software.

Por exemplo, considerando-se o Questionário de Avaliação (preerıchido aleatoriamerite) referente a KPA Gerenciamento de Requisitos (Quadro 5.6), obtém-se o Relatório de Ạtividades do Quadro 5.7

Quadro 5.6 - KPA Gerenciamento de Requisitos do Questionário de Avaliaçāo

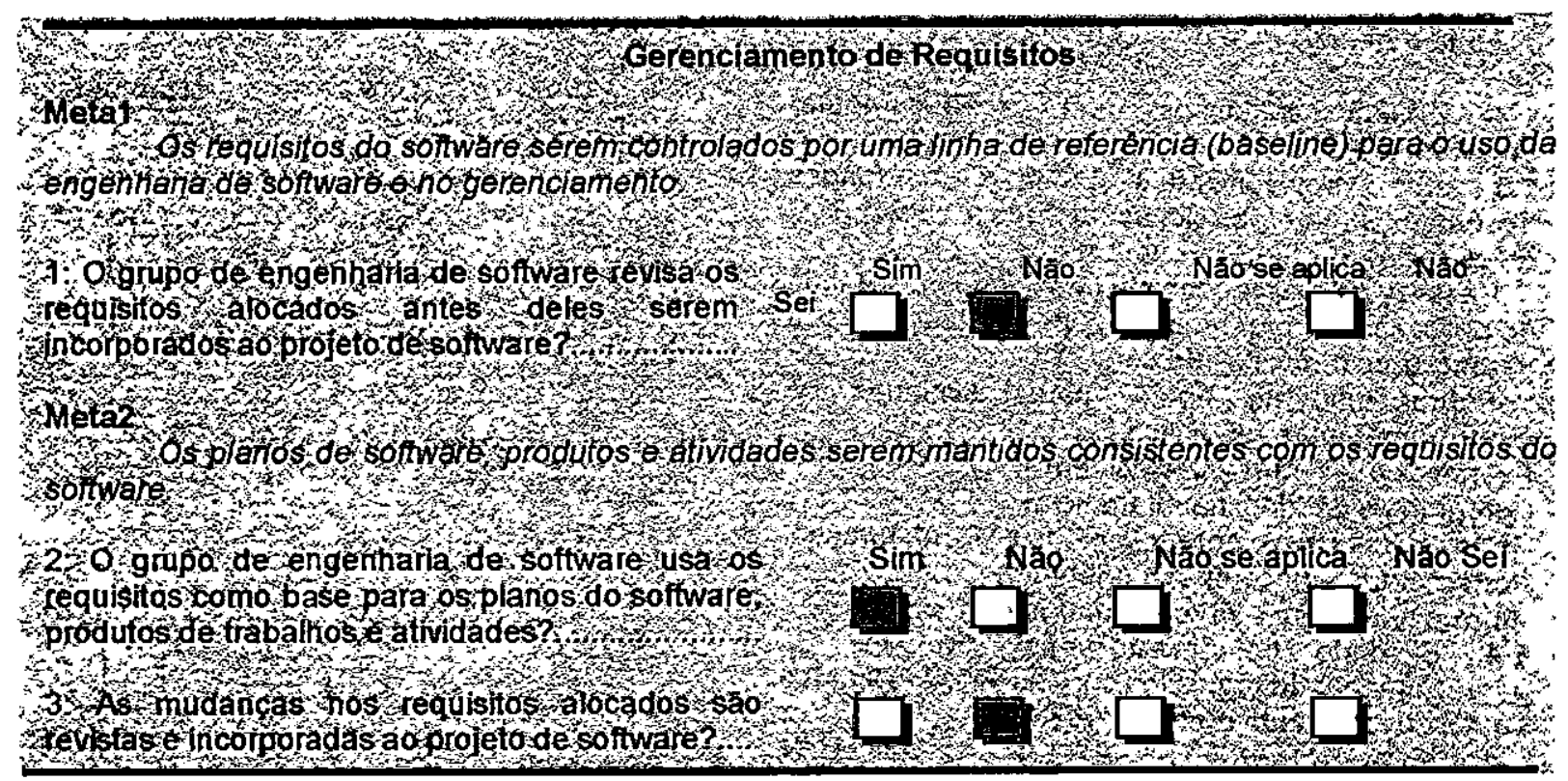

Quadro 5.7 - Relatório de Atividades

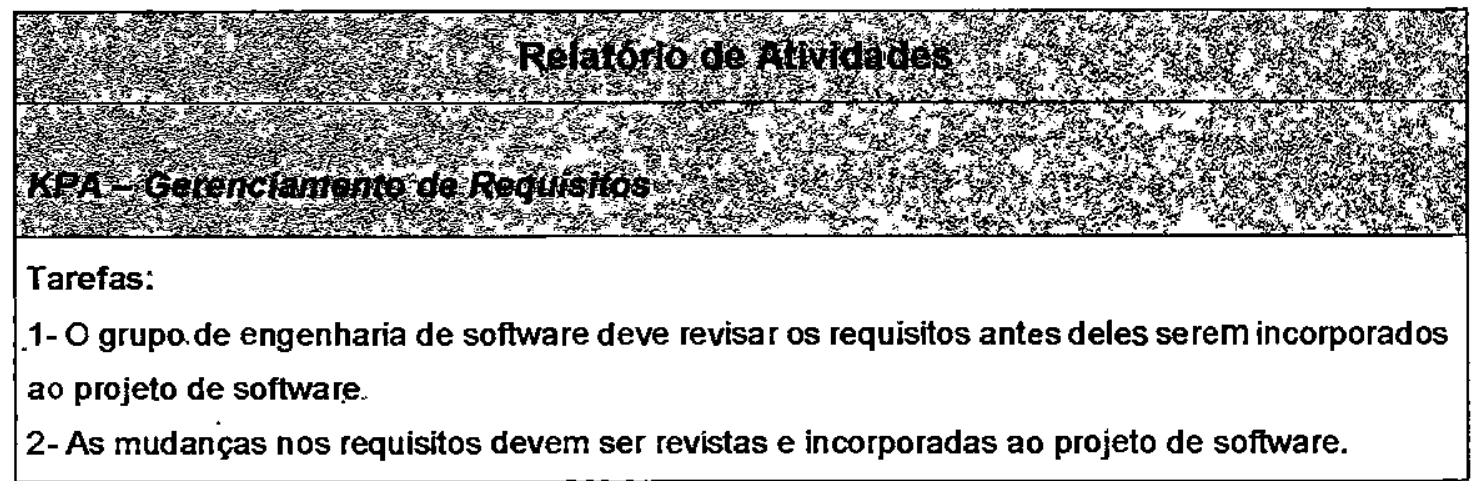




\subsection{3 - Tarefas do Plano}

A união das tarefas geradas nos dois relatórios (o Relatório de Pré-Condiçôes e o Relatório de Atividades) culmina nas tarefas do Plano de.Açăo a ser desenvolvido no terceiro passo das Diretrizes. Por exemplo, considerando o Relatório de Pré-Condições (Quadro 5.5) e o Relatório de Atividades (Quadro 5.7) referentes à KPA Gerenciamento de Requisitos, obtêm-se as tarefas a serem cumpridas para a realização dessa KPA (Quadro 5.8).

Quadro 5.8-Tarefas do Plano de Ação

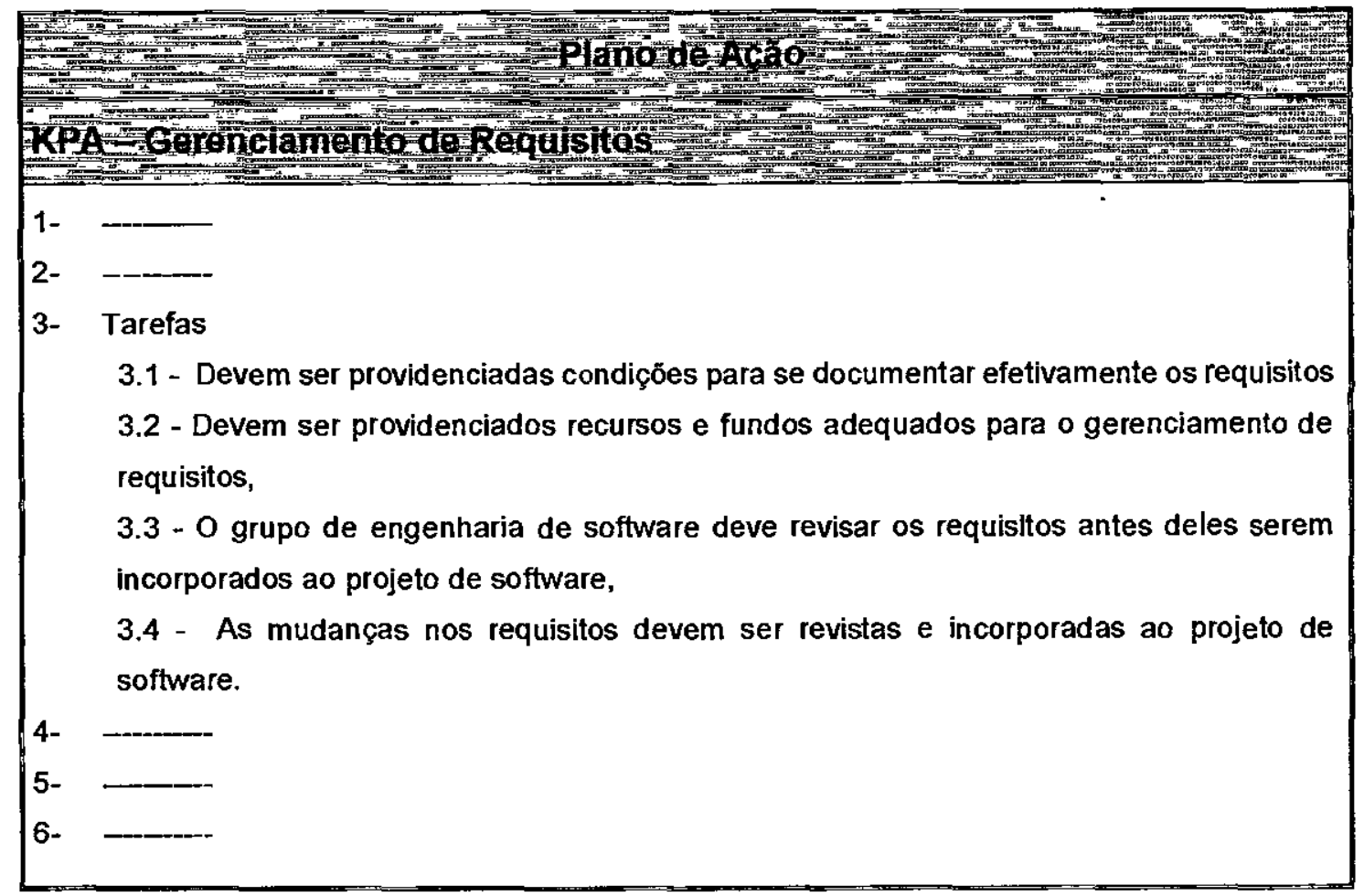

\section{5 - Passo 3 - Planejar Ações}

Um plano representa um método através do qual as tarefas podem ser definidas e executadas (Pacheco, 1997).

Ao iniciar o deservvolvimento de um plano é natural a dúvida sobre como começar e qual a forma mais adequada de apresentação das informaçōes.

A estrutura do plano de ação proposto baseou-se nos planos de ação do IEEEE (Institute of Electrical and Eletronics Engineers). O padrăo dos planos de ação do IEEE foi escoilhĩdo, uma vez que este padrăo não é um específico para determinado ramo da indústria, não exige grande 
experiência anterior para que um plano seja escrito, é aplicável a todo o ciclo de vida do software, abrange o controle sobre ernpresas subcontratadas ou fornecedoras de itens e as informações necessárias a este controle, provê uma lista de interfaces possíveis com as informaçōes mínimas necessárias em cada uma delas (Bounds, 1993).

O plano resultante da adoção do padrão IEEE tem a estrutura apresentada no Quadro 5.9 Quadro 5.9 - Estrutura do Plano de Ação

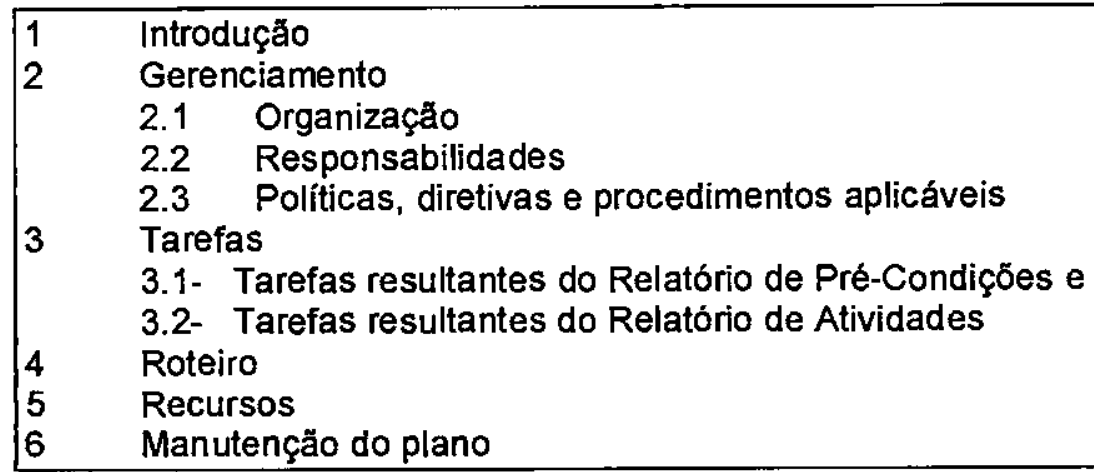

A seguir apresentam-se as seis seç̋̃es do plano:

\subsection{1 - Introdução do Plano}

Esta seção descreve o propósito do plano, as possíveis aplicações, termos-chave e referências. Quatro tópicos são importantes:

- Propósito: as primeiras necessidades de quem lê o plano são saber por que ele existe e quem deve lê-lo.

- Escopo: devem ser descritas as limitações e suposições sobre as quais o plano está baseado. Podem ser incluídas também previsões de custo e prazos, descrição do projeto onde será aplicado, ferramentas disponiveis, etc.

- Termos-chave: devem ser definidos para que se tenha uma terminologia única entre todos os usuários do plano.

- Referências: todas as referências que o plano fizer à políticas, padrões, procedimentos, terminologias ou outros documentos devem ser identificadas, para que os usuários possam ter acesso.

\subsection{2 - Gerenciamento}


Esta seção identifica os responsáveis e as autoridades que devem acompanhar as atividades planejadas. Devem ser descritas as unidades organizacionais envolvidas com o plano e as responsabilidades de cada unidade. É recomendável que registrem-se os atributos necessários e desejáveis para o ocupante de cada cargo.

\subsection{3 - Tarefas}

Esta seção descreve as tarefas técnicas e administrativas que devem ser executadas.

As tarefas são resultantes dos relatórios de Pré-Condições e de Atlvidades, desenvolvidos no passo anterior das Diretrizes.

\subsection{4 - Roteiro}

Esta seção descreve como será a coordenação temporal entre as tarefas.

A forma para a especificação da seqüência e coordenação das tarefas pode ser a mesma utilizada para determinar cronogramas de projetos, ou seja, através de um gráfico de Gantt, Pert ou Timeline. A determinação das datas pode ser feita utilizando-se datas absolutas, ou datas relativas a eventos a ocorrer.

\subsection{5 - Recursos}

Esta seção descreve os recursos que serão necessários para executar as tarefas. São identificados ferramentas de software, pessoal, treinamento e equipamentos.

As ferramentas podem ser padronizadas para todos os projetos ou pode haver ferramentas específicas para cada projeto.

Para cada ferramenta de software, seja ela adquirida extemamente ou desenvolvida juntamente com o projeto, o plano deve descrever ou referenciar suas funções.

\subsection{6 - Manutenção do Plano}

Esta seção descreve como manter o plano sempre atualizado. Isso envolve a identificação das atividades e responsabilidades necessánias para manter um controle contínuo sobre a execução do plano.

As seguintes informações devem estar presentes: 
- Quem é o responsável por monitorar o plano?

- Com que freqüências serão realizadas as atualizações?

- Como as atualizações serão avaliadas e aprovadas?

- Como as alterações serão efetivadas e comunicadas?

O plano deve ser revisto no início de cada fase do projeto. Quando as alterações propostas forem aprovadas todos os participantes da equipe devem ser informados.

\section{6 - Considerações Finais}

Neste capítulo foram apresentados os três passos das Diretrizes para o Estabelecimento de Melhoria de Processo de Software Adequada a Empresas de Pequeno Porte (o Estabelecimento de Prioridades, o Desenvolvimento da Abordagem e o Planejamento de Açठes), juntamente com

¿todos ós élementos envólvidós na mesima (o Plano para a Condução da Reuniăo de PréCondiçðes, a Palestra e o Questionário de Pré-Condiçðes).

No capítulo seguinte é apresentada uma análise da aplicabilidade das Diretrizes propostas. Vale ressaltar que essa análise foi realizada num âmbito bastante pequeno, necessitando ser mais amplamente efetuada. 
Capítulo 6

\section{Uma Análise Simples da Aplicabilidade das Diretrizes para o Estabelecimento de Melhoria de Processo Adequada a Empresas de Pequeno Porte}

\section{1- Considerações Iniciais}

Neste capitulo apresenta-se uma análise da aplicabilidade das diretrizes para o estabelecimento de melhoria de processo adequada a empresas de pequeno porte.

\section{2- Análise da Aplicabilidade das Diretrizes propostas}

Para a realização da análise da aplicabilidade das Diretrizes optou-se pela avaliação do seu conteúdo por especialistas (Kinnear \& Taylor, 1979).

Especialista é a definição atribuída a uma pessoa que possui conhecimentos profundos sobre um determinado assunto (Luft, 1994). Na análise em questão, foram considerados especialistas pessoas com conhecimentos em melhoria de processo de software, abordagem IDEAL e modelos de melhoria de processo de software (incluindo o SW-CMM). Fez-se necessário à determinação desses conceitos, uma vez que o conhecimentos dos mesmos é extremamente importante para uma correta análise das Diretrizes propostas.

Procurando analisar as Diretrizes sobre mais de um ponto de vista, decidiu-se realizar duas avaliações. A primeira avaliação contando com a colaboração de profissionais de empresas desenvolvedoras de software de pequeno porte, e a segunda avaliação contando com a colaboração de profissionais ligados a área acadêmica. A princípio, pretendeu-se realizar as duas 
avaliações em conjunto, em uma mesma reunião, para que os questionamentos pudessem ser discutidos ao mesmo tempo por todos os especialistas envolvidos.

Devido a incompatibilidade de horários, principalmente por parte dos profissionais das empresas de pequeno porte, as avaliações não puderam ser realizadas em conjunto, sendo necessário à realização de duas reuniões separadamente.

Para a realização das avaliações foram selecionados cinco especialistas, sendo três da área acadêmica e dois de empresas desenvolvedoras de software de pequeno porte. As duas reuniões foram agendadas e confirmadas antecipadamente. Antes das reuniões preparou-se um material contendo os passos das Diretrizes para o Estabelecimento de Melhoria de Processo e todos os elementos envolvidos (o Plano para Condução da Reunião de Pré-Condições, Palestra e o Questionário de Pré-Condições).

Preparou-se também um questionário para ser respondido e discutido com os especialistas. Esse questionário possui questões referentes à importância e a necessidade dos elementos envolvidos nas Diretrizes e também questões referentes à importância das informações geradas em cada um dos passos das Diretrizes (Quadro 6.1).

No início de cada reunião apresentou-se as Diretrizes para o Estabelecimento de Melhoria de Processo, explicando todos os passos e todos os elementos envolvidos.

A seguir são apresentados os pontos relevantes que foram levantados em cada uma das duas reuniões.

\subsection{1- Reunião com a Participação dos Profissionais de Empresas Desenvolvedoras de Software de Pequeno Porte}

Após a apresentação das diretrizes e de todos os elementos envolvidos, os profissionais responderam as questões (as respostas são apresentadas no Quadro 6.2) e fizeram alguns questionamentos considerados relevantes:

1- Os profissionais julgaram o preenchimento do Plano de Ação para a Condução da Reunião de Pré-Condições uma "formalidade desnecessária" em empresas de pequeno porte. Julgaram desnecessário o desenvolvimento e o preenchimento de um plano para conduzir uma reunião em uma empresa onde o número de funcionários é geral pequeno. No caso de se contar com o plano de ação, os profissionais sugeriram 
plano de ação fosse apresentado nas Diretrizes com algumas seções já preenchidas, uma vez que essas seções dificilmente mudariam.

Por exemplo, a seção Introdução (a qual especifica o objetivo do plano), a seção de Tarefas (a qual especifica as tarefas a serem realizadas durante a reunião) e a seção Cronograma (a qual especifica o tempo para cada tarefa reunião) seriam apresentadas já preenchidas.

Ficaria a cargo da organização, o preenchimento somente dos campos das seções de Gerenciamento (a qual especifica o local, a data, o horário, o coordenador, os participantes e a meta da reunião) e Recursos (a qual envolve os recursos necessários para a realização de uma reunião proveitosa, como por exemplo, a existência de tantas cadeiras quanto participantes).

2- Quanto à necessidade da apresentação da Palestra de Pré-Condições, os profissionais julgaram que em empresas de pequeno porte, onde existem poucos funcionários, que ao invés da apresentação da palestra, deveria ser realizada uma "conversa menos formal" com os participantes, comentando os tópicos cobertos pela palestra e esclarecendo dúvidas.

\subsection{2- Reunião com a Participação dos Profissionais da Área Acadêmica}

Após a apresentação das diretrizes e de todos os elementos envolvidos, os profissionais responderam as questões (as respostas são apresentadas no Quadro 6.3) e fizeram alguns questionamentos considerados relevantes e apresentados a seguir:

1- Considerou-se bastante importante o fato da decisão de priorização ser tomada em consenso com a gerência da organização, uma vez que, mesmo de posse dos resultados do Relatório de Priorização, os objetivos de negócio da organização, os quais envolvem o auto-conhecimento da organização, o posicionamento atual da organização no mercado, as expectativas com relação ao futuro e a determinação dos meios e dos recursos necessários para que a organização atinja os seus objetivos de curto, médio e longo prazo, são de extrema importância. Em se tratando de empresas de pequeno porte, muitas vezes, o capital e o tempo acabam sendo os fatores mais importantes.

2- Considerou-se necessário o preenchimento do Plano de Ação para a Condução da Reunião de Pré-Condições e a apresentação da Palestra de Pré-Condições. Além da necessidade do preenchimento do Plano de Ação para que a Condução da Reunião de 
Pré-Condições ocorra de uma maneira mais proveitosa e organizada, e a importância da apresentação da Palestra de Pré-Condições para auxiliar as pessoas no preenchimento do Questionário de Pré-Condições, considerou-se esses pontos importantes também na tentativa de iniciar uma mudança cultural, com relação às imposições necessárias quando se pretende estabelecer a melhoria de processo de software em uma organização.

Quadro 6.1- Questões consideradas na análise da aplicabilidade Diretrizes para o Estabelecimento de Melhoria de Processo Adequada a Empresas de Pequeno Porte

1- Você considera importante o preenchimento do Plano para Condução da Reunião de Pré-Condições?<smiles>O=[N+]([SeH])C1CCC1</smiles>

2- Você acha necessária a apresentação da Palestra de Pré-Condições?

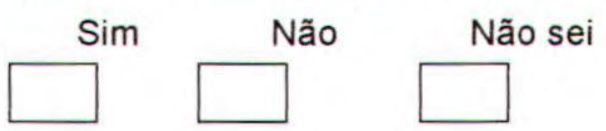

3- Você concorda que a determinação das prioridades de implantação de área-chave de processo deva ser uma decisão de consenso tomada pela gerência da organização?

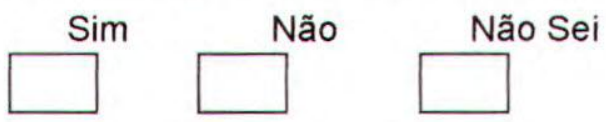

4- Você acha que as informações fornecidas através do Relatório de Pré-Condições são úteis para a decisão de determinação de prioridades?

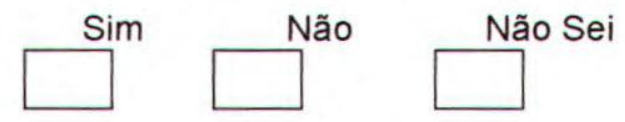

5- Você acha que as informações obtidas através do Relatório de Atividades são úteis para a decisão de determinação de prioridades?

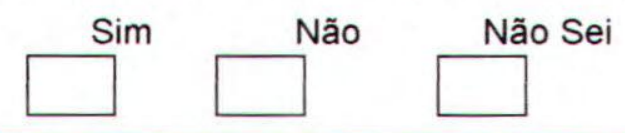

Quadro 6.2- Respostas dos Profissionais das Empresas de Pequeno Porte

\begin{tabular}{|c|c|c|c|c|c|}
\hline Profissional & Questão 01 & Questão 02 & Questão 03 & Questão 04 & Questão 05 \\
\hline 01 & Não & Não & Sim & Sim & Sim \\
\hline 02 & Não & Não & Sim & Sim & Sim \\
\hline
\end{tabular}


Quadro 6.3- Respostas dos Profissionais da Área Acadêmica

\begin{tabular}{|c|c|c|c|c|c|}
\hline Profissional & Questão 01 & Questão 02 & Questão 03 & Questão 04 & Questão 05 \\
\hline 01 & Sim & Sim & Sim & Sim & Sim \\
\hline 02 & Sim & Sim & Sim & Sim & Sim \\
\hline 03 & Sim & Sim & Sim & Sim & Sim \\
\hline
\end{tabular}

\section{3- Considerações Finais}

Neste capitulo apresentou-se uma análise da aplicabilidade das Piretrizes para o Estabelecimento de Melhoria de Processo Adequada as Empresas de Pequeno Porte. É importante ressaltar que essa análise foi realizada num âmbito bastante pequeno, necessitando ser mais amplamente efetuada.

No capitulo seguinte são apresentadas as conclusões deste trabalho e os possiveis trabalhos futuros. 


\section{1- Considerações Gerais}

Com a constante demanda gerada pela vida moderna, cada vez mais os computadores passam a integrar a rotina diária das pessoas e a produção de software vem tendo um aumento constante. Com isso, os consumidores estão se tomando cada vez mais exigentes, não se importando apenas com o preço, mas também com um produto sem defeito, confiável e que atenda às suas necessidades (Gillies, 1993).

Após anos de experiência no desenvolvimento de software, percebeu-se que alguns fatores exigidos pelos clientes náo estão relacionados especificamente às características de qualidade do produto final e sim à forma como o processo de software é gererıciado e controlado, ou seja, controlando e gerenciando o processo de software tem-se maior probabilidade de obter um produto final que atenda as exigências dos clientes.

A melhoria do processo de software é uma tarefa complexa e envolve multos fatores. Para auxiliar nessa melhoria, existem hoje na literatura, vários modelos de melhoria de processo de software, porém a maioria desses modelos é voltada para as empresas de grande porte e dificilmente se ajustam a realidade das empresas de pequeno porte (as quais, segundo o Ministério de Ciência e Tecnologia (Qualidade, 1998) somam 77\% das empresas desenvolvedoras de software brasileiras). 
Mesmo quando essas empresas tentam iniciar a melhoria de processo usando um desses modelos, elas esbarram 'em um 'empecilho muito grande. Os modelos são "fechados", eles indicam "o que" deve ser feito mas não dizem "como" as atividades que proporcionam a melhoria devem ser realizadas.

\section{2- Contribuições deste Trabalho}

Dentro do contexto de melhoria de processo de software, a proposição das Diretrizes para o Estabelecimento de Melhoria de Processo adequada a Empresas de Pequeno Porte, a qual culmina em planos de ação para as atividad̦es de melhoria, é um passo importante na determinação de atividades mais claras e objetivas, que possam ser facilmente utilizadas e seguidas pelas empresas desenvolvedoras de software brasileiras.

Fez parte deste trabalho a realização de uma Análise Simples da Aplicabilidade das Diretrizes propostas. Essa análise foi realizada em um âmbito bastante pequeno, porém, mesmo sendo pequena, essa análise ressaltou um fator bastante importante, e muitas vezes complicador em melhoria de processo de software, denominado "mudança cultural".

A mudança cultural é um ponto, dentro da melhoria de processo de software, bastante complexo. Percebeu-se pela análise realizada neste trabalho que, os profissionais das empresas de pequeno porte, mesmo necessitando melhorar o seu processo de software para poderem obter um produto com mais qualidade e continuarem competindo no mercado, eles não se conscientizam que essa melhoria exige certas obrigaçōes a mais, como por exemplo, uma maior formalidade. A falta de tempo e a falta de recursos não deveriam ser fatores justificativos para a informalidade:

A conscientização da importância de alguns fatores, como por exemplo, o formalismo, é um dos ọbjetivos que se deseja atingir com o preenchimento do Plano para a Condução da Reunião de Pré-Condições e também com a apresentaçăo da Palestra, que fazem parte do passo 1 Estabelecimento das Prioridades - das Diretrizes e que foram, na análise realizada, justamente os pontos considerados pelos profissionais das empresas de pequeno porte como desnecessários..

É importante ressaltar que não faz parte do trabalho desta dissertaçăo julgar se realmente as empresas de pequeno porte têm condições de cumprir todas as atividades exigldas no rível dois do SW-CMM, ou se elas desejam mais do que o nível 2. De qualquer forma, o modo como as Diretrizes propostas neste trabalho são relatadas permite que outras KPAs sejam facilmente 
adicionadas ou retiradas do modelo de melhoria voltado a empresa de pequeno porte. Isso se dá ao fato de existir orieritação para o desenvolvimento dos relatórios que dão origem aos planos de ação.

\section{3- Trabalhos Futuros}

- O deserivolvimento de um trabalho visando ajudar as organizações a mudarem sua cultura em relaçăo à necessidade de se melhorar o processo de software, aceitando as responsabilidades e realizando todas as tarefas que essa mudança acarreta. Isso pode ser desenvolvido, por exemplo, através de um modelo baseado no P-CMM - People Capability Maturity Model. O P-CMM tem como objetivo estratégico a melhoria das capacidades das organizações de software, através do aumento da capacidade da sua força de trabalho, assegurando que a capacidade de desenvolvimento de software seja um atributo da organização e não aperlas de alguns poucos indivíduos.

- O relatório de atividades proposto nas Diretrizes deste trabalho pode ser mais detalhado se, por exemplo, for considerada a Norma ISO/IEC 12207, a qual estabelece um modelo comum para os processos do ciclo de vida do software. Nessa Norma a terminologia é bem defirida e pode ser referenciada pela indústria de software [ISO/IEC 12207, 1995].

- Foi deserivolvida no ICMC-USP uma ferramenta denominada Software Process Quality SProQ, a qual automatiza a avaliação de processo de software proposta por Erıdo. Essa ferramenta permite que o instrumerito de pesquisa seja facilmente modificado com a inclusão ou exclusão de questões que se relacionam às práticas-chave das KPAs do nível 2 do SW-CMM. Uma continuidade ao trabalho desta dissertação pode ser a utilização da ferramerita SproQ para automatizar o Questionário de Pré-Condições, dando rapidamente os resultados relacionados aos pré-requisitos para a realização das atividades das KPAs do nivel 2 do SW-CMM.

- Uma modificação na ferramenta SproQ poderia gerar automaticamente; os dois relatórios (Relatório de Atividades e Relatório de Pré-Condições) utilizados ra fase de desenvolvimento de abordagem das diretrizes para o estabelecimerito de melhoria de processo de software, visto que esses relatórios são produzidos completando-se as práticas-chave rião cumpridas pela KPA 


\section{Referências Bibliográficas}

(Ahlgren, 1999)

(Buckley, 1994)

(Bounds, 1993)

(CMM/SEl, 1993)

(Curtis, 1998)

(Dunaway, 1996)

(Endo, 1998)

(Furlan, 1997)
AHLGREN, M. CMM Light for SMEs. (online) (08/03/1999) Disponivel na Internet: <http://www.espi.co.uk/spider/papers/qlabs2.html >

BUCKLEY, F. J. Implementing a Software Configuration Management Enviroment, IEEE Computer, v.27, n.2 , p. 56-61, 1994.

BOUNDS, NADINE, DART, S.A. Configuration Management (CMM) Plans: The Beginning to Your CM Solution. Pittsburg, Software Engineering Institute, Camegie Mellon University, 1992.

Capability Maturity Model, Versão 1.1, 1993.

CURTIS, B. Which Comes First, the Organization or its Processes ? IEEE Software, v.15, n.6, p. 10-13, 1998.

DUNAWAY, D. K. e MASTERS, S. CMM Based Appraisal for Internal Process Improvement: Method Description, Relatório Técnico TR-96007, Software Engineering Institute, 1996.

ENDO, C. Uma Estratégia para Iniciar Melhoria de Processo de Software, São Carlos, 1998. 76p. Dissertaçåo (Mestrado) Instituto de Ciências Matemáticas e de Computação, Universidade de Săo Paulo.

FURLAN, J. D. Modelagem de Negócio - Uma Abordagem Integrada de Modelagem Estratégica Funcional de Dados e a Orientaçåo a Objetos, Makron Books, São Paulo, 1997. 
(Gillies, 1993)

(Glass, 1998)

(Gremba, 1999)

(Haase, 1994)

(IDEAL, 1999)

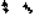

(Intec, 1999)

(SO/IEC 12207, 1995)

(Júbileu, 1999)

(Kinear \& Taýlor, 1979)

(Kuvaja, 1994)

(Luft, 1994)

(Maidantchik, 1996)

(Marciniat, 1994)

(Pacheco, 1997)

(Paulk et al., 1993)
GILLIES, A. Software Quality: Theory and Management, Chapman\&Hall, Longmàn, 1993.

GLASS, R. L. Defining Quality Intuitively, IEEE Software, v.15, n.3, p 103-104, 1998.

GREMBA, J.; MYERS, C. The IDEAL Process Model: A Practical Guide for Improvement (online). (01/02/1999). Disponivel na Intemet: <http://mww.sei.cmu:edu/activities/ideal//deal.bridge.html>

HAASE, V. Bootstrap: Fine-Tuning Process Assessment. IEEE Software, v.11, n.4, p. 25-35, 1994.

IDEAL. (online) (01/02/1999). Disponivel na Intemet: $<$ http://www.SEl.cmu.edu:80/ideal/ideal.bridge.html>

INTEC. (online) (06/04/1999). Disponivel na Intemet: $<$ http://unw.intec.cl>

ISO/IEC 12207, Information Technology - Software LIfe Cicle Process, First Ediction, 01/08/1995.

JUBILEU, A. P. Aquisiçāo de Conhecimento como Apoio ao Método de Engenharia Reversa FUSION - RE/I, São Carlos, 1999. 131p. Dissertaçăo (Mestrado) Instituto de Ciências Matemáticas e de Computação, Universidade de São Paulo.

KiNN̂̀NEAR, T. C. TAYLCOR, J. R. Marketing Research: Apllied Approach, New York, McGraw-Hill, 1979.

KUVAJA, P. et al. Software Process Assessment \& Improvement The Bootstrap Aproach, Blackwell Publishers, 1994.

LUFT, C. P. Mini Dicionário Luft, 5º Edição, Săo Paulo, 1994.

MAIDANTCHIK, C. Melhoria de Processo de Desenvolvimento de Software. In: X Simpósio Brasileiro de Engenharia de Software,SBES, 1996.

MARCINIAT, J. J. Encyclopedia of Software Engineering, Wiley Intersciense Publications, v.II, p. 851-869, 1994.

PACHECO, R. F. SANCHES R. Gerenciamento de Configuração de Software, Relatório Técnico - ICMSC, n. 57, junho, 1997.

PAULK, M. C.; Curtis, B.; Chrissis, M. B.; Weber, C. V. Capability Maturity Model for Software. versão 1.1, Pittsburgh, Software Engineering Institute, Carnegie Melon University, 1993. (CMU/SEI-93TR-24) 
(Pfleeger, 1994)

(Qualidade, 1998)

(Rosa, 1997)

(SEI, 1999)

(SPICE1, 1997)

(SPICE7, 1997)

(Vásquez, 1998)

(Werkema, 1995)

(Wilson, 1998)
PFLEEEGER, S. L. ROMBACH, H.D. Measurement based process . improvement, IEEE Software, v.11, n.4, p. 9-11, 1994

QUALIDADE. Qualiḍade no Setor de Software Brasileiro, Brasília, n.2, p.27, 1998

ROSA, P. G. Modelo de Avaliação de Processo de Software para Pequena Empresa - MAPPE. São Carlos,1997. 90p. Dissertação (Mestrado) - Instituto de Ciências Matemáticas e de Computação, Universidade de São Paulo.

SOFTWARE ENGINEERING INSTITUTE. (online) (22/02/1999).

Disporível na Internet:

$<$ http://unw.sei.cmu.edu/activities/cmm/cmm.sum.html>

Software Process Assessment - Part 1: Concepts and Introductory Guide, Versão 1.00, 1997.

Software Process Assessment - Parte 7: Guide for use in Process Improvement, versão 1.00, 1997.

VÁSQUEZ, F. R. F. Desarrollo de un Plan de Acción para el Mejoramiento del Proceso de Software, Orientado a la Realidad Nacional, Valparaíso, 1998. 89p., Univesidad Técnica Federico Santa Mảría.

WERKEMA, M. C. C. Ferramentas Industrias Básicas para o Gerenciamento de Processos, Fundảção Christiano Ottoni, 1995.

WILSON, M. G. Gestion de Riesgos y sus Aplicationes, los Metodos S:PRIME y S:PLAN. In: IX Conferência Intemacional de Tecrologia de Software: Qualidade de Software (CITS), Curitiba, p. $99-104,1998$. 


\section{Bibliografia Complementar}

(Basili, 1995)

(Cavano, 1978)

(DOD - Std 2168)

(Goodbrand, 1997)

(Grady, 1997)

(IEEE Std 729 - 1983)

(Juran, 1970)

(Kirner, 1997)
BASILI, V. R. CALDIERA. G. ROMBACH, H. D. Goal-Question-Metric Paradigm, Encyclopedia of Software Engineering, John Wiley \& Sons, Nova York, v.1, p.527-532, 1995.

CAVANO, J. P. MCCALL, J. A. A Framework for the Measurement of Software Quality, Proceeding ACM Software Quality Assurence Workshop, novembro, 1978.

Dod-Std-2168, Department of Defense Standard of Software Quality Evaluation.

GOODBRAND, A. Software Process Improvement. (online). (05/02/1999).Disponivel na Internet:

<http://uww.cpsc.ucalgary.ca/ alang/SENG 621/present.htm>

GRADY, R. B. Successful software process improvement, Prentice-Hall, Nova Jersey, 1997.

IEEE Standard Glossary of Software Engineerlng Terminology, Software Engineering Technical Commitee of the IEEE Computer Society, 1983.

Juran, J. M. Gryna, Jr. Quality Planning an Analysis From Product Development to Use, McGrall-Hill, Nova York, 1990.

KIRNER, T. G. ABIB, J. C. Uso da Abordagem GQM na Avaliaçăo da Qualidade de Software. In; Workshop de Qualidade de Software (WQS), Fortaleza, 1997. 
(Pressman, 1994)

(Rombach, 1987)

(Sanders, 1994)

(Smith, 1989)

(Tsukumoto, 1995)

(Xenos, 1997)
PRESSMAN, R. S. Software Engineering - A Practitioner's Approach. Edição Européia. McGraw-Hill, 1994.

ROMBACH, H. D. A Controled Experiment on the Impact of Software Structure on Maintainability, IEEE Transaction on Software Engineering, v.SE-13, 1987.

SANDERS, J. CURRAN, E. Software Quality - A framework for success in software development and suport, Addison-Wesley, 1994.

SMITH, D. J.; WOOD, K. B. Engineering Quality Software - A review of current practices standards and guidelines including new methods and development tool, Elsevier Science Publishers Ltd., 1989.

TSUKUMOTO, N. A., et al. Modelos de Processo de Software: Visão Global e Análise Comparativa, Fundação CTI - Brasil, Campinas, 1995.

XENOS, M. CHRISTODOULAKIS, D. Measuring perceived software quality. Information and Software Technology, v.39, n.6, p. 417 424, 1997. 


\section{Apêndice A}

(A Palestra de Pré-Condições) 


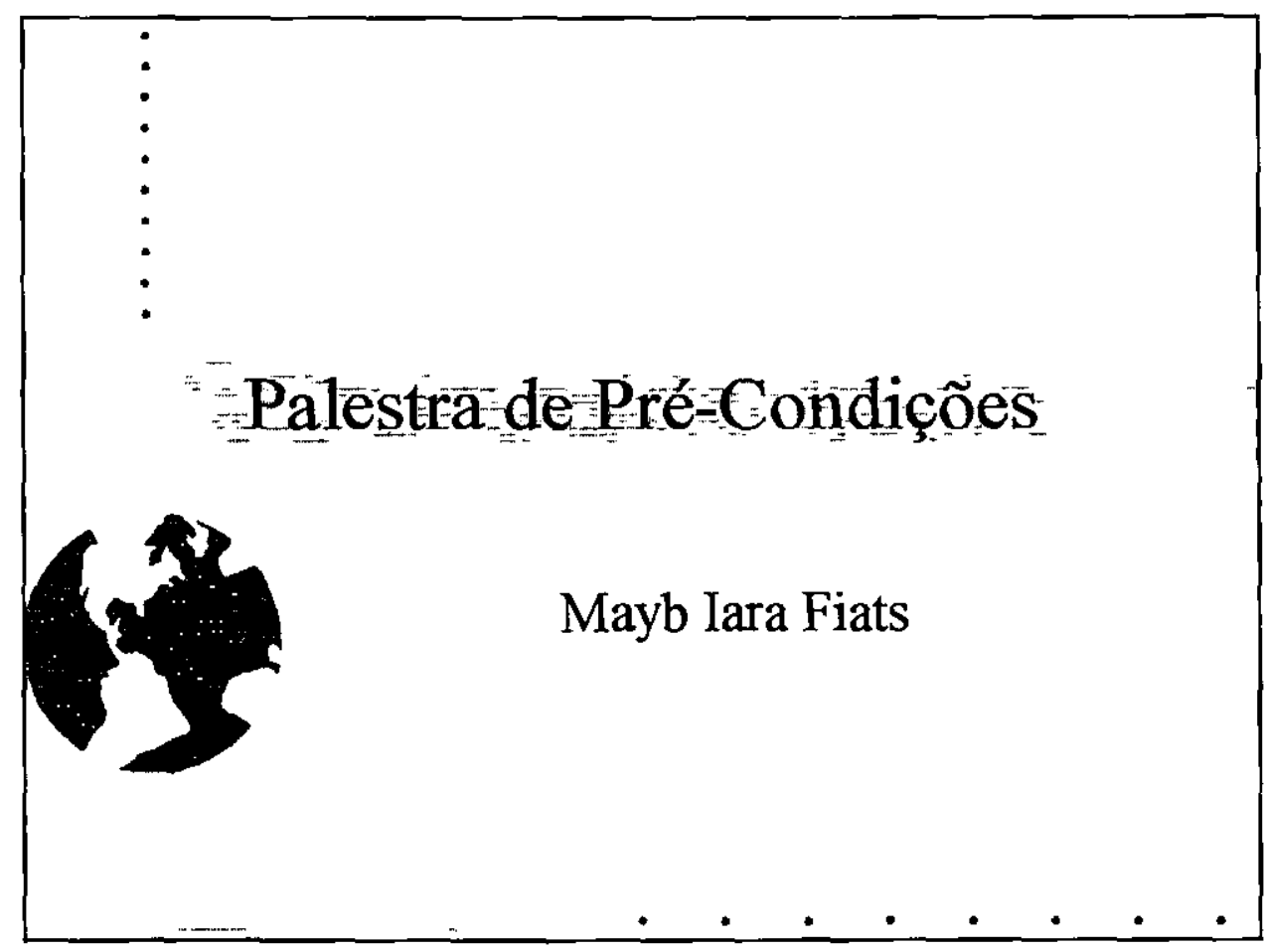

\section{Visão Geral}

$-\cdots-\ldots-\ldots$

- Introdução

- Melhoria de Processo de Software

- Abordagem IDEAL

- Diretrizes de Estabelecimento de Melhoria de Processo de Software

- KPAs do nível dois do SW-CMM 
A baixa qualidade nos processos de software gera vários problemas às empresas desenvolvedoras de software, como altos custos de manutenção e atrasos no cronograma

Uma solução para esses problemas é a Melhoria do Processo de Software
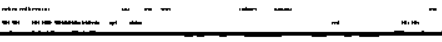

Melhoria de Processo:

Define as atividades que a organização deve seguir para melhorar o processo ao longo do tempo

As atividades tornam-se mais gerenciáveis durante o desenvolvimento e manutenção do software, o que aumenta a visibilidade do processo 


\section{Melloria de Processo}

É uma decisão de negócio que depende de toda a organização

Seus resultados geralmente não podem ser percebidos instantaneamente

Muitos elementos como comprometimentos, responsabilidades, recursos e habilidades profissionais e gerenciais devem ser . considerados

Palostra do Pré-Condiçđes

$\because$

Melhoriade Processo

Benefícios:

Aumenta a motivação dos funcionários

Diminui riscos

Melhora as condições de trabalho

Melhora a imagem da empresá

Aumenta a satisfação do cliente 

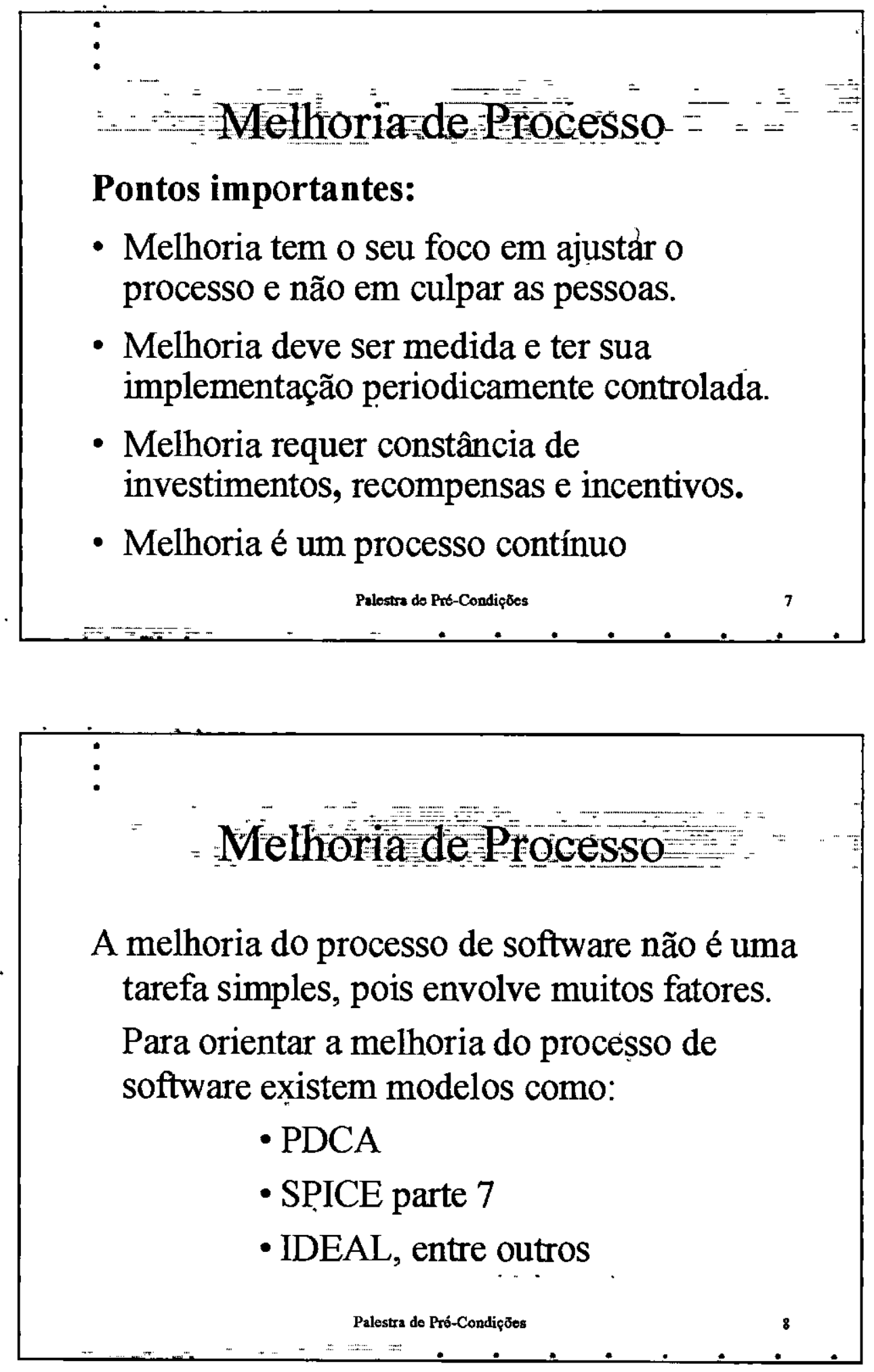


\section{Melloria de Processo}

A melhoria do processo de software não é uma tarefa simples, pois envolve muitos fatores. Para orientar a $\begin{aligned} & \text { As Diretrizes para o } \\ & \text { Estabelecimento de }\end{aligned}$ software existen

- PDCA

Melhoria de Processo

- SPICE Abordagem IDEAL

- SPICE po

- IDEAL, entre outros.
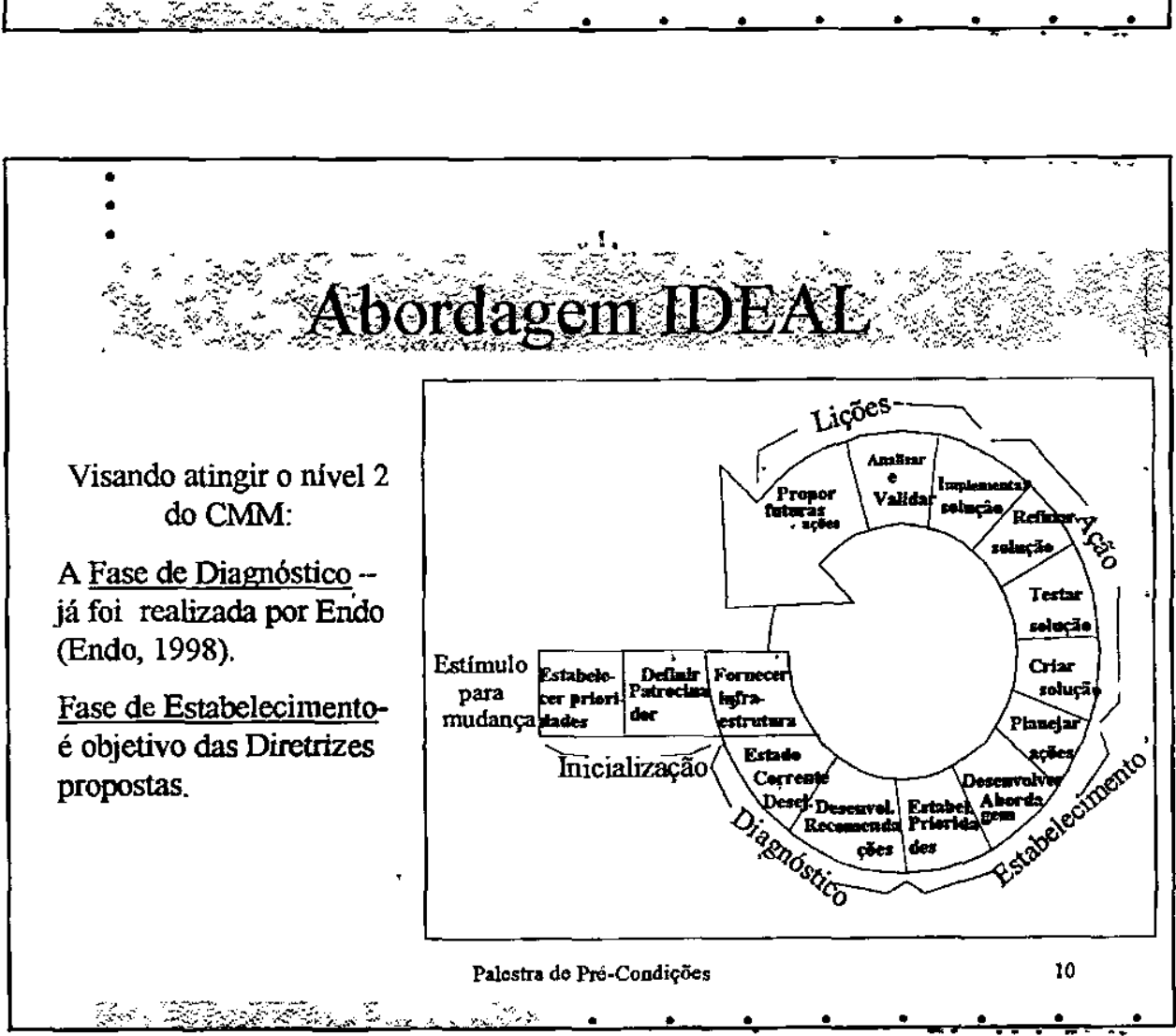

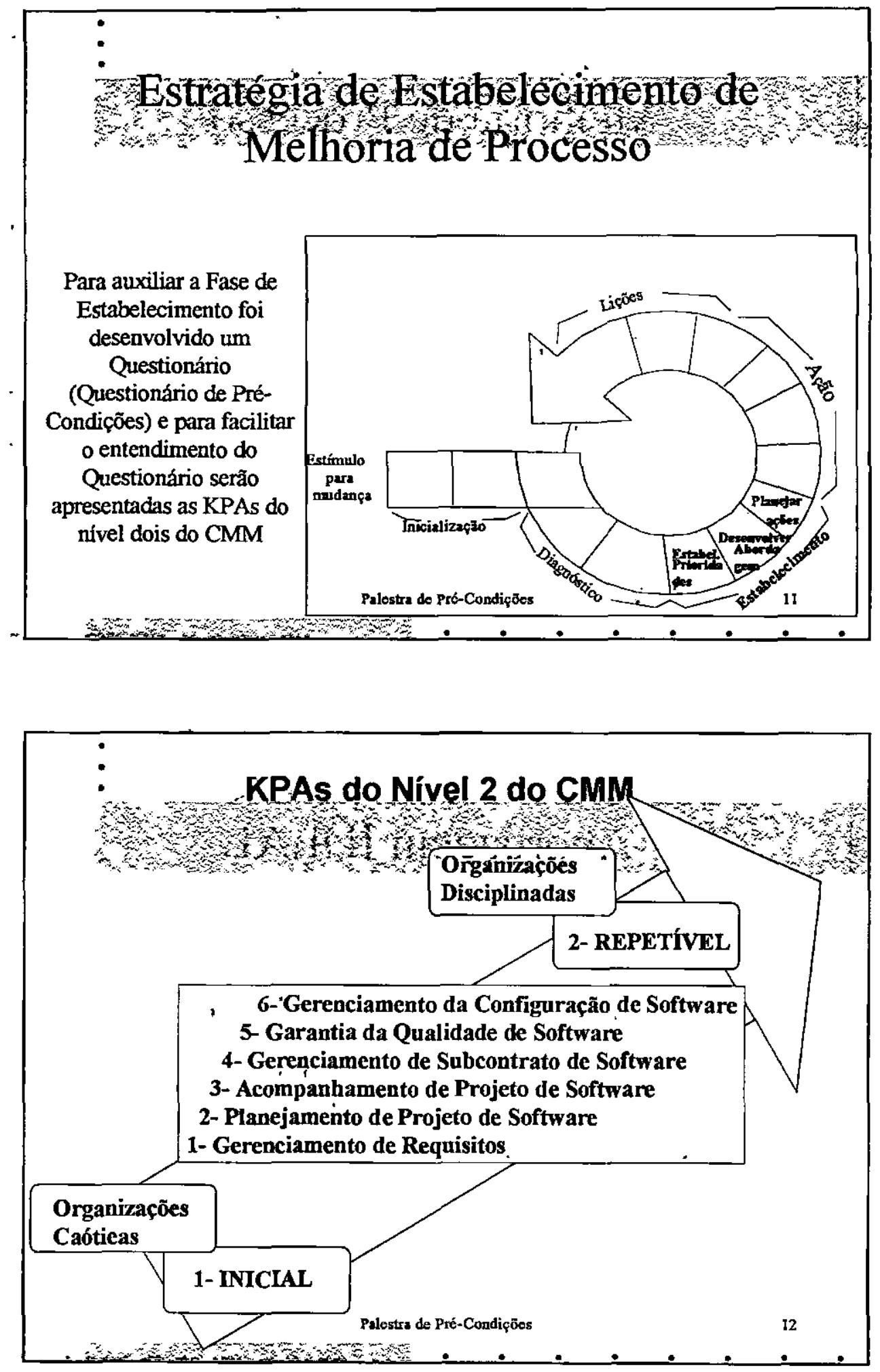

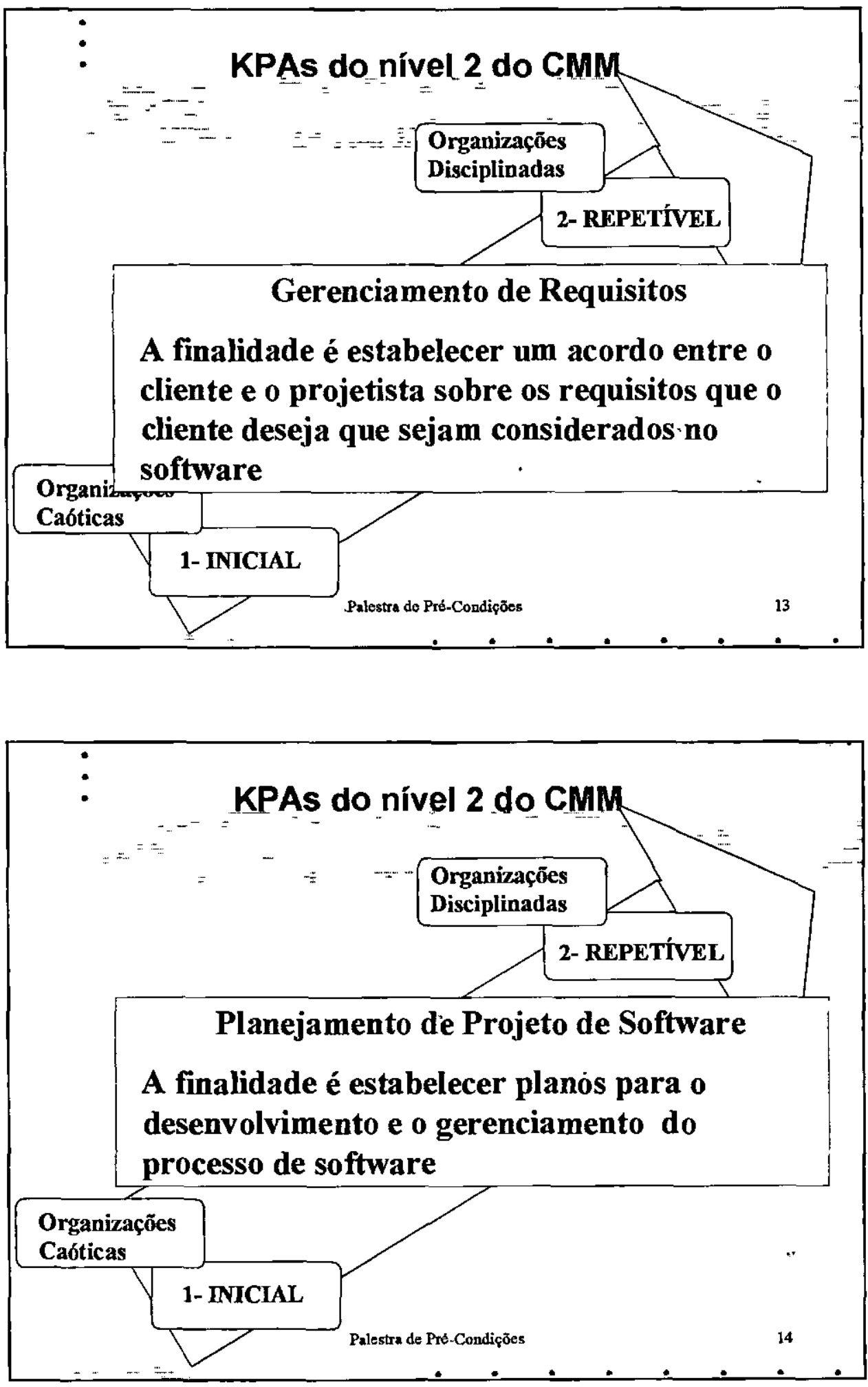

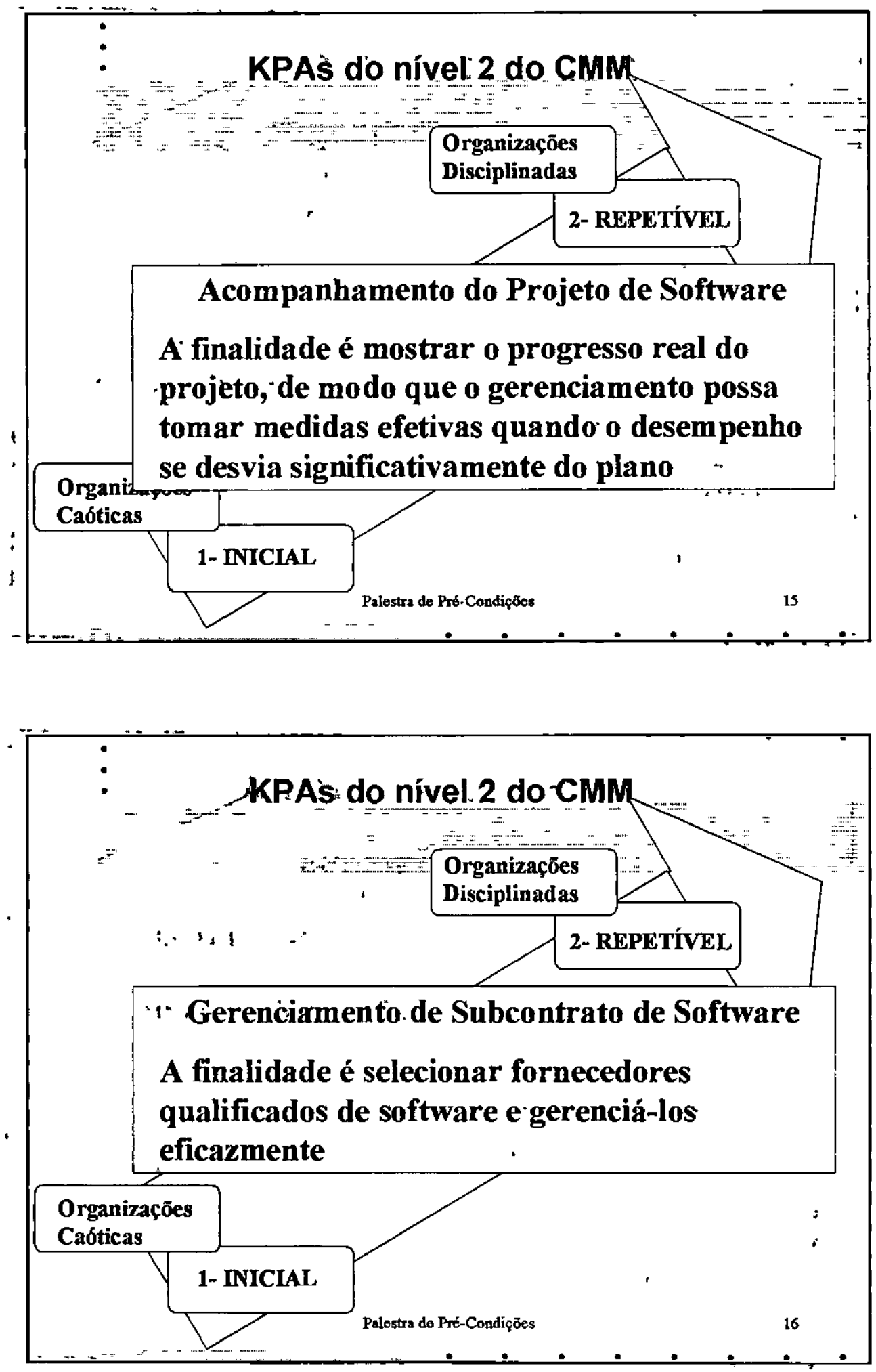

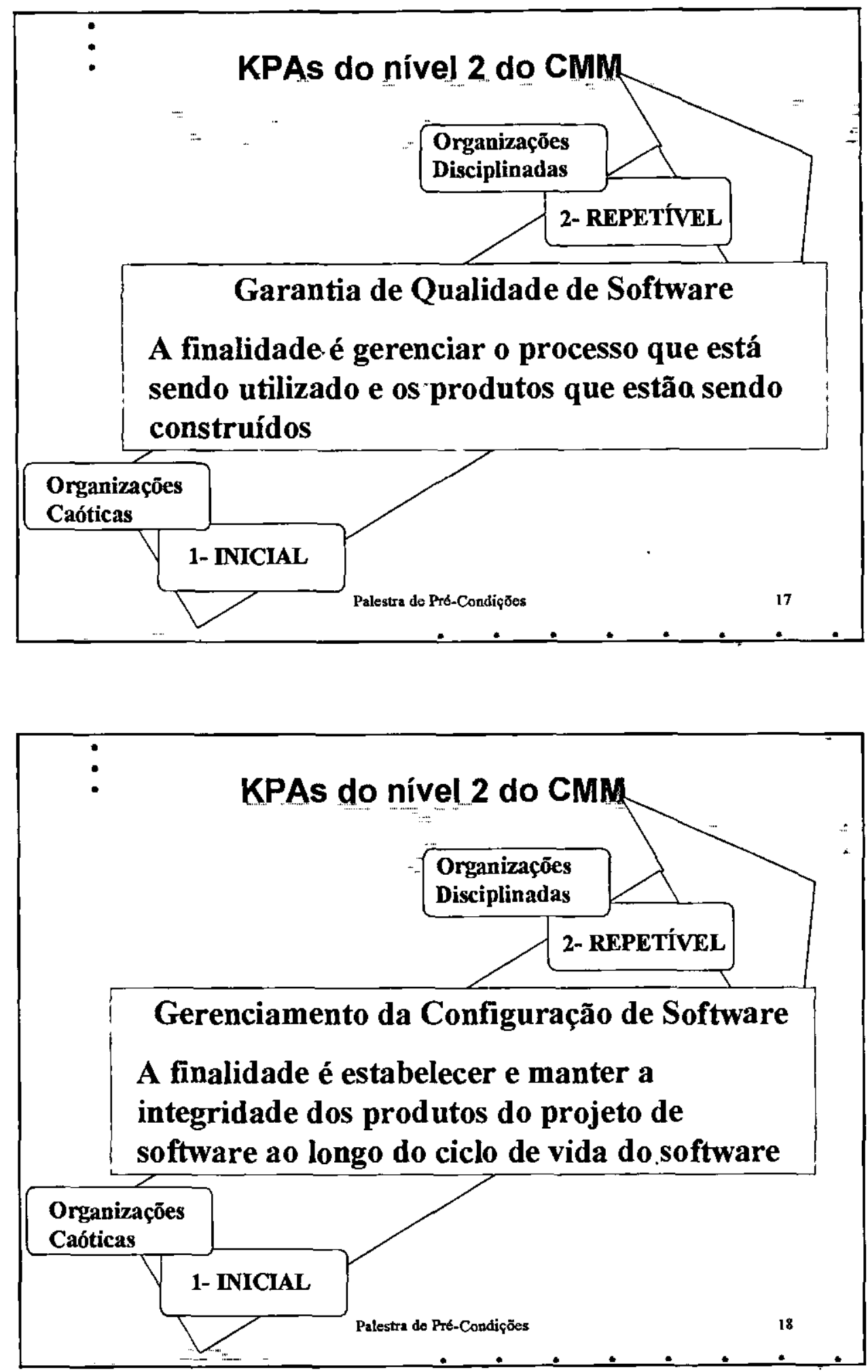


\section{Apêndice B}

(O Questionário de Pré-Condições) 


\section{Questionário}

Data:

1

1- Gerenciamento de Requisitos

O propósito do Gerenciamento de Requisitos é o estabelecimento de um acordo entre o cliente e o projetista do software sobre os requisitos que o cliente deseja que sejam considerados no software. Os requisitos de software incluem os requisitos não técnicos (condiç̃es ou termos contratuais que afetam as atividades de projeto do software, tais como os produtos de software a serem liberados e as datas de entrega), os requisitos técnicos (que incluem as funçб̄es de integração do usuário final, do operador e de suporte, os requisitos de desempenho, as restrições de projeto, as linguagens de programação e os requisitos de interface), e os critérios de avaliação para verificar se os produtos de software satisfazem os requisitos desejados.

1.1- Para cada projeto, sāo atribuidas responsabilidades para análise e documentaçăo dos requisitos do sistema e a alocação desses requisitos para hardware, software e outros componentes do sistema?

Essas responsabilidades cobrem:

- Gerenciamento e documentacão dos requisitos do sistema e sua alocacão através da vida do projeto.

- Administração das alterações nos requisitos do sistema e na alocagão dos requisitos.

1.2-Os requisitos são efetivamente documentados?

1.3. São providenciados recursos e fundos adequados para o gerenciamento dos requisitos?

Estes recursos e fundos cobrem:

- Pessoas com experiência e habilidade no domínio de aplicagão e engenharia de software designadas a gerenciar os requisitos de software,

-Ferramentas de apoio, para atividades de gerenciamento de requisitos.

Exemplos de ferramentas incluem:

- programas de planilha eletrônica,

-ferramentas para o gerenciamento de configuragão,

- ferramentas de acompanhamento $e$.

-ferramentas para o gerenciamento de testes.

1.4- $\dot{E}$ dado treinamento nas atividades de gerenciamento de requisitos para as pessoas ligadas ao desenvolvimento do software?
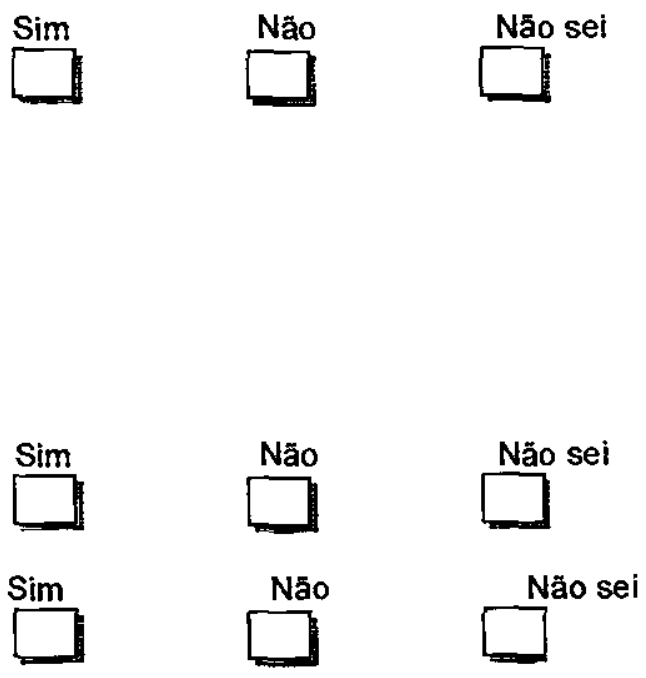

Anotaçōes:

\section{2- Planejamento de Projeto de Software}

O propósito do Planejamento de Projeto de Software é o estabelecimento de planos para o desenvolvimento e gerenciamento do processo de software. Isso envolve o desenvolvimento de estimativas, a determinação dos compromissos e a definição de um plano para a realização do trabalho. 
No planejamento do processo de software estima-se o tamanho do produto de software e os recursos necessários, produz-se um cronograma, identifica-se e avalia-se os riscos do software e negocia-se os compromissos.

O planejamento de software inicia-se com uma avaliação do trabalho a ser realizado; as restrições e os objetivos que definem e limitam o projeto de software.

$\mathrm{O}$ resultado da atividade de planejamento é um plano contendo o ciclo de vida do projeto de software, uma lista de produtos a serem entregues ao cliente, prazos, estimativas para o mível de esforço, recursos, ferramentas de suporte e riscos do projeto.

2.1-É estabelecida uma declaração de trabalho para o projeto de software que seja documentada, aprovada, gerenciada e controlada?

Uma declaração de trabalho para o projeto de software deve:

- Envolver o escopo do trabalho, as metas e os objetivos técnicos,

- Identificar:

- os clientes e os usuários finais,

- os padróes impostos,

- as responsabilidades designadas.

- as restrições e as metas de custo e cronograma,

- as dependências entre o projeto de software e outras organizações,

- as réstrições e metas de recursos e outras restrições e.

- metas para o desenvolvimento e/ou manutengão,

2.2- Såo atribuidas responsabilidades para a elaboração do plano de desenvolvimento de software?

Estas responsabilidades cobrem:

- A coordenagão do planejamento do projeto de software $e$,

- A divisão e designação formal de responsabilidades para as atividades $e$ os produtos de trabalho.

2.3- Săo providenciados recursos e fundos adequados para o planejamento do projeto de software?

Estes recursos e fundos cobrem:

- Pessoas com experiência e habilidade em aplicações de planejamento de software designadas para desenvolver o plano do projeto de software e,

- Ferramentas de apoio para dirigir as atividades de planejamento de projeto de software.

Exemplos de ferramentas incluem:

- programas de planilha eletrônica,

- modelos de estimativas $e_{\text {. }}$

-planejamento de projeto e de cronograma de programas.
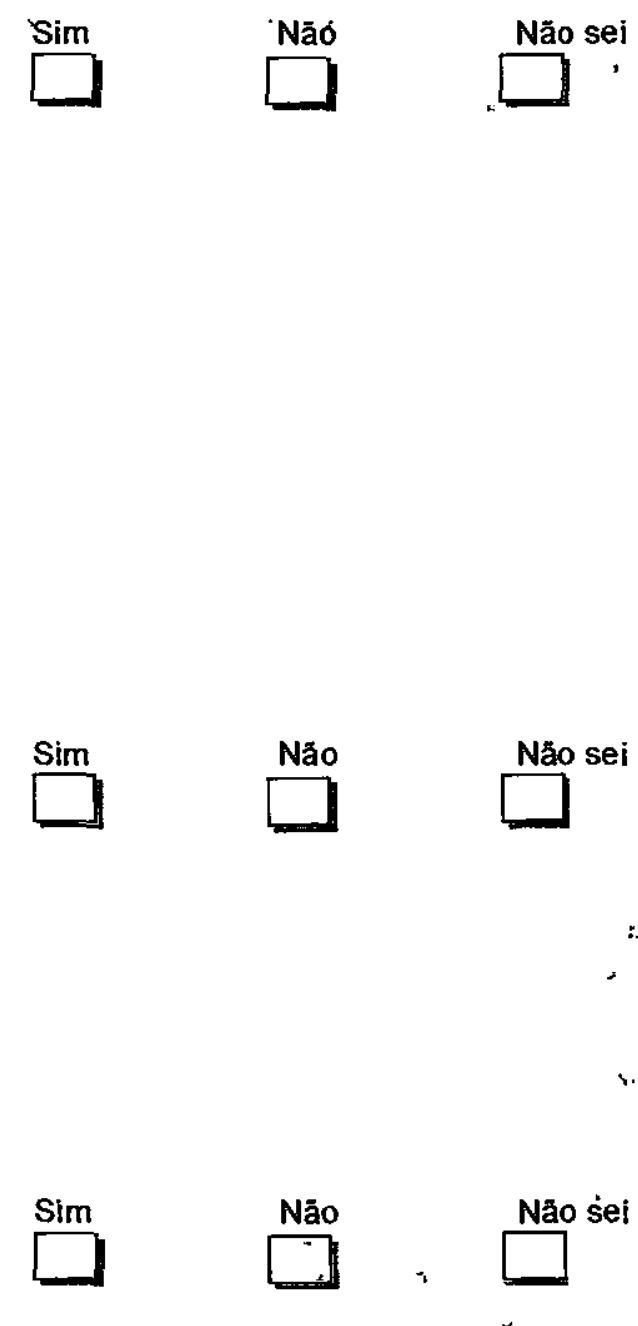
2.4- É dado treinamento em procedimentos de planejamento e estimativa de software para as pessoas envolvidas no planejamento do projeto de software?

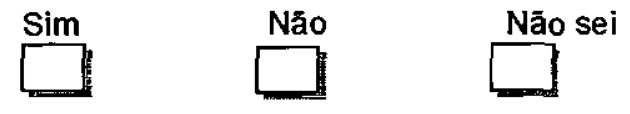

Anotaçōes:

\section{3- Acompanhamento e Supervisão do Projeto de Software}

O propósito do Acompanhamento e Supervisão de Projeto de Software é mostrar o progresso real do projeto, de modo que o gerenciamento possa tomar medidas efetivas quando o desempenho se desvia significativamente do plano. O acompanhamento e supervisão do projeto de software envolve acompanhar e revisar os resultados e as realizações do software confrontando com as estimativas documentadas, os compromissos e os planos. Envolve também ajustar os planos com base nọs resultados e realizações efetivamente alcançados. Os mecanismos utilizados para isso podem ser revisões internas e revisões formais com os clientes. Quando ocorre um desvio entre os planos e os resultados efetivos, deve-se alterar a forma como o trabalho está sendo feito e/ou ajustar os planos.

3.1- O plano de desenvolvimento de software é documentado e aprovado?

3.2- Säo atribuídas expllcitamente responsabilidades de acompanhamento das atividades e dos produtos de trabalho de software?

Essas responsabilidades cobrem o acompanhamento:

- Dos produtos de trabalho de software a serem desenvolvidos ou dos serviços a serem fornecidos,

- Do esforço,

- Do custo,

- Do cronograma e,

- Do orçamento para as atividades de software.

3.3- Såo providenciados recursos e fundos adequados para o acompanhamento do projeto de software?

Estes recursos e fundos cobrem:

- Pessoas com responsabilidades específicas para 0 plane jamento do projeto de software $e$,

- Ferramentas de apoio para as atividades de acampanhamento e supervisão do projeto de software. Exemplos de ferramentas incluem:

- programas de planilha eletrônica e.

- programas de planejamento do projeto e cronogramas.

3.4- $\dot{E}$ dado treinamento em gerenciamento de aspectos pessoals e técnicos do projeto de software para as pessoas envolvidas no acompanhamento do projeto de software?

3.5- Săo fornecidas orientaçðes sobre os aspectos técnicos do projeto de software para os gerentes de enftursta?
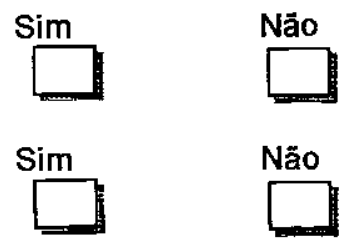

Näo sei

Não

Năo sei
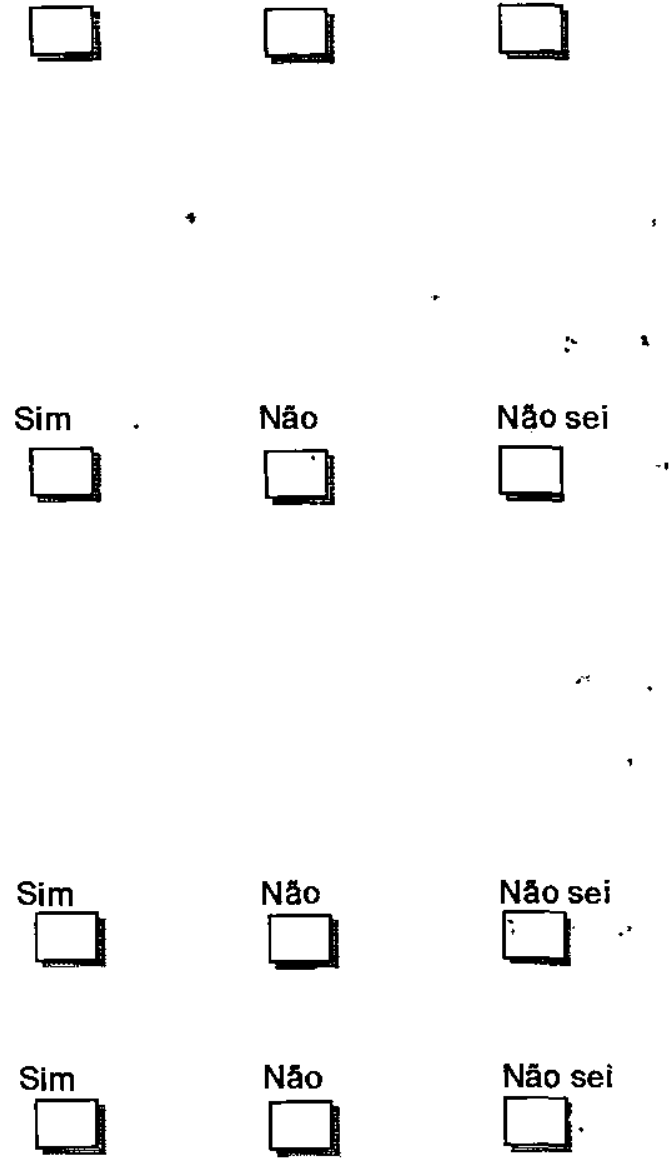
software?

Exemplos de orientações incluem:

- padrões e procedimentos de engenharia de software $e$,

- o domínio de aplicações do projeto.

Anotaçōes:

\section{4- Gerenciamento de Subcontratados de Software}

O propósito do Gerenciamento de Subcontratados de Software é a seleção de fơmecédores qualificados e o gerenciamento eficaz desses fornecedores. Isso envolve a seleção do fornecedor, o estabelecimento de compromissos, o acompanhamento e a revisão do desempenho e dos resultados obtidos. O Gerenciamento de subcontratados de software inclui o software, o hardware e possivelmente outros componentes do-sistema:

O subcontratado é selecionado baseado em sua habilidade para desenvolver o trabalho, na sua estratégia de negócio é em considerações técnicas.

$\mathrm{Na}$ seleção e gerenciamento do subcontratado são necessáriòs documentos como: cláusula de contrato, requisitos do projeto, produtos a serem entregues, padrões e procedimentos a serem seguidoș.

Ao se fazer o subcontrato, é estabelecido e usado como base para o gerenciamento do subcontrato, um acordo documentado cobrindo requisitos técnicos e não técnicos.

O trabalho a ser feito pelo subcontratado e o plano para o trabalho devern ser documentados.

4.1- São providenciados recursos e fundos adequados para a seleçăo do subcontratado de software e o gerenciamento do subcontrato?

Esses recursos $e$ fundos cobrem:

- Pessoas com responsabilidades específicas para o gerenciamento do subcontrato $e$,

- Ferramentas de apoio para o gerenciamento de subcontrato.

Exemplos de ferramentas incluem:

- modelos de estimativas,

- programas de planilha eletrônioa e gerenciamento de projeto e,

- cronograma de programas.

4.2- E dado treinamento em estabelecimento e gerenciamento de subcontrato para as pessoas envolvidas nessas atividades?

4.3- Säo fornecidas orientaçöes sobre os aspectos técnicos do sübcontrato aos gerentes de software e aós outros indivíduos envolvidos no gerenciamento do subcontrato de software?

Exemplos de orientaçōes dos aspectos técnicos do projeto incluem:

- o domínio de aplicação.

- a tecnologia de šoftware que está sendo aplicada,

- as ferramentas de software que estão sendo usadas.

- as metodologias que estão sendo usadas,

- os padrões e os procedimentos que estão sendo usados.
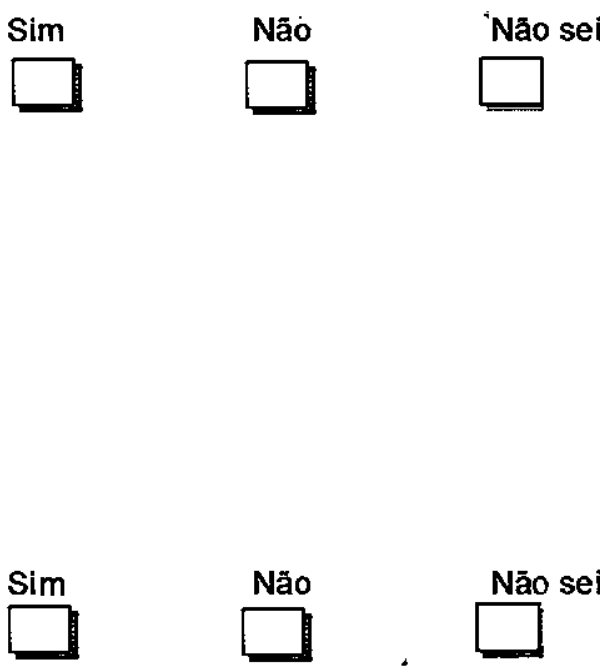

Nāo sei
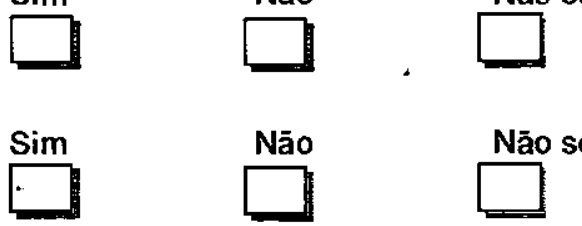

Nāo sei

Anotaçöes: 
5- Garantia de Qualidade de Software

O propósito da Garantia de Qualidade de Software é o gerenciamento do processo que está sendo utilizado e dos produtos que estão sendo construídos. Isso envolve a realização de revisões e de auditorias nos produtos de software e nas atividades para assegurar que estão em conformidade com os padrões e procedimentos aplicados. Envolve também o fornecimento desses resultados aos gerentes envolvidos. $O$ grupo de garantia de qualidade de software trabalha com o projeto de software desde os estágios iniciais para $o$ estabelecimento de planos, padrões e procedimentos para melhorar o projeto de-software e satisfazer. as restrições do projeto e as políticas da organização.

5.1- É estabelecido um grupo responsável pela implementação e coordenação das atividades de garantia de qualidade de soffware para o projeto?

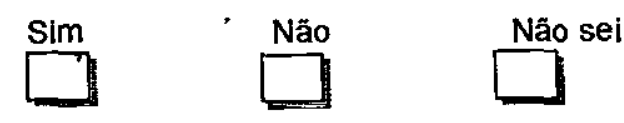

5.2- São providenciados recursos e fundos adequados para a execução das atividades de garantia de qualidade de software?

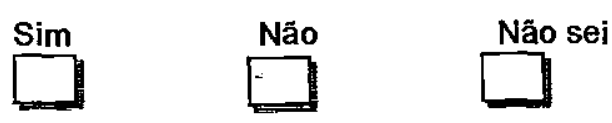

Esses recursos e funidos cobrem:

- Pessoas com responsabilidadés específicas para a garantia de qualidade de software do projeto,

- Uma pessoa com conhecimento do papel da ganantia de quaiidade de software e que tenha autoridade para tomar ações apropriadas diante de atividades não cumpridas $e$,

- Ferramentas de apoio às atividades da garantia de qualidade de software.

Exemplos de ferramentas incluem;

- programas de banco de dados.

- programas de planilha eletrônica $e$.

- ferramentas de auditoria.

5.3-É dado treinamento em garantia de qualidade de software para as pessoas envolvidas nessas atividades?

5.4- São fornecidas orientaçoes sobre o papei, as responsabilidades, a autoridade e o valor do grupo de garantia de qualidade de software aos membros do projeto?

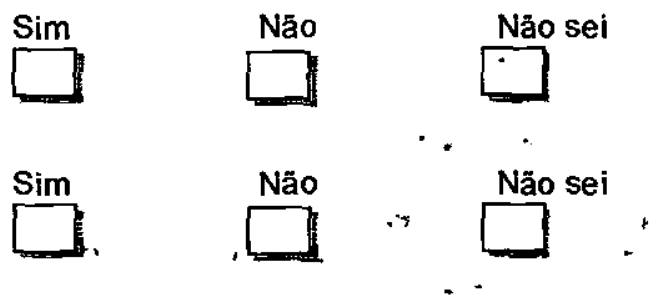

Anotaçỏes:

6- Gerenciamento de Configuração de Software

$O$ propósito do Gerenciamento de Configuração de software é estabelecimento e a manutenção da integridade dos produtos do projeto de software ao longo do çiço de vida. Isso envolve identificação da configuração do software, o controle sistemático das alteraçõ̃es e a manutenção dà integriäadè da configuração ao longo do ciclo de vida. $O$ gerenciamento de configuraçãa utiliza linhas de referência (baselines) que servem como um marco no ciclo de vida do software. Os itens que passsam por uma liniha de referência podem ser alterados somente através de procedimentos formais de controle de mudảnçaš."

6.1- É estabelecido um Grupo de Controle de Configuraçảo de Software (GCCS) responsável peio

Sim

Não

Não sei 
controle dos itens de configuração de software do projeto?

As atividades do GCCS incluem:

- Autorização do estabelecimento de linhas de referência e a identificação de itens de configuração,

- Representação dos interesses do gerente de projeto e de todos os grupos que podem ser afetados por mudanças das linhas de referência do software. (Exemplos de grupos afetados podem ser o grupo de garantia de qualidade de hardware, gerenciamento de configuração de hardware, engenharia de hardware, engenharia de software, engenharia de sistema, sistema de teste, garantia de qualidade de software, gerenciamento de configuração de software, gerenciamento de contrato e documentação de apoio.)

- Revisão e autorização das mudanças para as linhas de referência de software,

- Autorização da criação de produtos para a biblioteca de itens de configuração de software.

6.2- É estabelecido um Grupo de Gerenciamento de Configuração de Software (GGCS) responsável pela coordenação e implementação do Gerenciamento de Configuração de Software para o projeto?

O GGCS coordena ou implementa:

- a criação e administração da biblioteca de itens de configuração de software,

- o desenvolvimento, a manutenção e a distribuição dos planos, padrōes e procedimentos do gerenciamento de configuração de software,

- a identificação de um conjunto de produtos de trabalho a serem colocados sob o gerenciamento de configuração de software,

- o gerenciamento do acesso à biblioteca de itens de configuração de software,

- a atualização dos itens de configuração de software - a criação de produtos a partir da biblioteca de itens de configuração de software,

- o armazenamento das ações do gerenciamento de configuração de software e,

- a produção e a distribuição de relatórios de gerenciamento de configuração de software.

6.3- São providenciados recursos e fundos adequados para a execução das atividades do gerenciamento de configuração de software?

Esses recursos e fundos cobrem:

- Pessoas com responsabilidades específicas para o gerenciamento de configuração de software $e$,

- Ferramentas de apoio para as atividades do gerenciamento de configuração de software.

Exemplos de ferramentas incluem:

- programas de banco de dados e,

- ferramentas de gerenciamento de configuração.

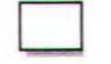


6.4-É dado treinamento em objetivos, procedimentos e métodos aos membros do GGCS?

6.5- $E$ dado treinamento nas atividades do gerenciamento de configuração de software aos membros do grupo de engenharia de software e outros grupos relacionados ao software?

Exemplos de grupos relacionados ao software incluem:

- o grupo de garantia de qualidade de software $e$,

- o grupo de documentação de apoio.

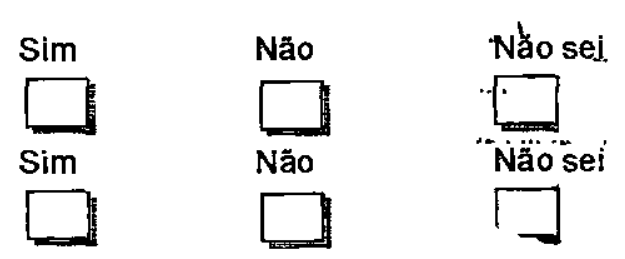

Anotaçōes: 